UNIVERSIDADE DE SÃO PAULO

INSTITUTO DE BIOCIÊNCIAS

INSTITUTO DE FÍSICA

INSTITUTO DE QUÍMICA

FACULDADE DE EDUCAÇÃO

MICHELE DAYANE FACIOLI MEDEIROS

Indicadores de Alfabetização Científica em uma aula experimental investigativa sobre fotossíntese e respiração celular para o sétimo ano do ensino fundamental. 


\title{
Indicadores de Alfabetização Científica em uma aula experimental Investigativa sobre fotossíntese e respiração celular para o sétimo ano do ensino fundamental.
}

\begin{abstract}
Dissertação apresentada ao Instituto de Física, Instituto de Química, Instituto de Biociências e á Faculdade de Educação da Universidade de São Paulo para obtenção do titulo de Mestre em Ensino de Ciências.

Área de Concentração: Ensino de Biologia.

Orientador: Prof. Dr. Marcelo Tadeu Motokane
\end{abstract}

VERSÃO CORRIGIDA 
Autorizo a reprodução e divulgação total ou parcial deste trabalho, por qualquer meio convencional ou eletrônico, para fins de estudo e pesquisa, desde que citada a fonte.

\section{FICHA CATALOGRÁFICA \\ Preparada pelo Serviço de Biblioteca e Informação do Instituto de Física da Universidade de São Paulo}

Medeiros, Michele Dayane Facioli

Indicadores de alfabetização científica em uma aula experimental investigativa sobre fotossíntese e respiração celular para o sétimo ano do ensino fundamental. São Paulo, 2016.

Dissertação (Mestrado) - Universidade de São Paulo. Faculdade de Educação, Instituto de Física, Instituto de Química e Instituto de Biociências

Orientador: Prof. Dr. Marcelo Tadeu Motokane

Área de Concentração: Ensino de Biologia

Unitermos: 1. Biologia - Estudo e ensino; 2. Alfabetização científica; 3. Ensino por investigação; 4. Aulas experimentais.

USP/IF/SBI-052/2016 
Dedico este trabalho ao meu orientador, que confiou em mim. 


\section{AGRADECIMENTOS}

Ao Prof $^{\circ}$ Dr. Marcelo Tadeu Motokane pela orientação, confiança, amizade, por todos os ensinamentos não somente relacionados à vida profissional, mas também pessoal. Meus sinceros agradecimentos pelo apoio durante todos esses anos de convivência, pelo carinho e por ser um exemplo que levarei para o resto da vida.

À Prof ${ }^{a} \operatorname{Dr}^{\mathrm{a}}$ Mariana do Valle e ao $\operatorname{Prof}^{\circ}$ Dr $^{\circ}$ Marcelo Pereira pela dedicação na leitura do meu trabalho e pelas valiosas contribuições no exame de qualificação.

Aos meus pais, Euripa e Itamar meu porto seguro, agradeço todos os esforços que realizaram para me educar.

Agradeço à minha mãezinha Nossa Senhora Aparecida por me amparar em todos os momentos...

As minhas irmãs, Cibele Nataliane e Carol Jheniffer e ao meu irmãozinho Artur, que são um pedaço de mim.

Agradeço ao Walter por estar sempre ao meu lado, ser meu amigo e companheiro, por me apoiar em todos os momentos e por deixar minha vida completa.

Ao meus amigos do grupo LINCE ( Luziene, Caio, Rafael, Bruce, Tereza, Thiago, Sofia, Maurício, Renato, Mayumi) pelo incentivo, pelo carinho, e pela disponibilidade e generosidade em compartilhar comigo seus conhecimentos; e claro pelas muitas risadas.

Agradeço ao Brucce Sanderson um grande amigo sempre disposto a me ajudar.

À Ana Claudia Cazarotti pela amizade sincera e por me apresentar o Prof ${ }^{\circ}$ Marcelo e seu grupo de pesquisa.

Aos meus queridos alunos, fonte de motivação e de aprendizagem na minha vida.

À Escola Arlinda Rosa Negri pelo apoio e parceria. 


\section{RESUMO}

Medeiros, M.D.F. Indicadores de Alfabetização Científica em uma aula experimental investigativa sobre fotossíntese e respiração celular para o sétimo ano do ensino fundamental. 2016. 101 f. Dissertação (Mestrado)- Faculdade de Educação, Instituto de Biociências, Instituto de Física e Instituto de Química da Universidade de São Paulo.

A alfabetização científica é um processo que capacita os estudantes se posicionarem de modo crítico às questões científicas presentes no cotidiano. Para isso, mais que memorizar termos e conceitos, faz-se necessário a comprensão por parte dos alunos do papel da ciência na sociedade, bem como dos aspectos envolvidos na produção do conhecimento científico. Para a promoção deste processo de Alfabetização Científica em sala de aula é necessário que as atividades propostas aos alunos propiciem momentos para o desenvolvimento de habilidades próprias do fazer científico. Segundo Sasseron e Carvalho (2008) essas habilidades ocorrem em atividades investigativas e se constituem em Indicadores de Alfabetização Científica, que foram posteriormente ampliados por Penha, Vianna e Carvalho (2009). Dessa forma, o presente trabalho teve por objetivo investigar como são as atividades experimentais, no contexto do ensino por investigação, que promovem a Alfabetização Científica. A escolha pela atividade experimental se deu ao fato de que muitos professores acreditam que esta seja uma estratégia essencial para o ensino de ciências. Com esse propósito, uma aula experimental investigativa aplicada aos alunos do sétimo ano do ensino fundamental foi analisada e em seguida, foi identificado Indicadores de Alfabetização Científica presente nesta atividade, bem como a frequência com que estes indicadores aparecem em cada etapa da aula proposta. Os resultados apontaram que a atividade experimental, no contexto do ensino por investigação, possibilitou os alunos desenvolverem, além das habilidades propostas por Sasseron e Carvalho (2008) e por Penha, Viana e Carvalho (2009), outra habilidade requerida na formação de individuo alfabetizado científicamente, configurando assim um ambiente propício para o desenvolvimento de habilidades específicas. De tal modo, a presença dos indicadores de Alfabetização Científica na atividade experimental investigativa está diretamente relacionada com a maneira que a atividade é estruturada pelos professores. Ademais, em aulas de ciências, para o entendimento de um conceito específico é necessário a abordagem de conceitos interdisciplinares, por vezes considerados coadjuvantes pelos professores, porém 
quando bem trabalhados em aula experimental é decisivo para a resolução do problema proposto pela atividade investigativa.

Palavras chave: Alfabetização Científica, Ensino por Investigação, Aulas experimentais. 


\begin{abstract}
Medeiros, M.D.F. Scientific Literacy indicators in a Investigativa trial lesson on photosynthesis and cellular respiration for the seventh grade of elementary school. 2016. 101 f. Dissertação (Mestrado)- Faculdade de Educação, Instituto de Biociências, Instituto de Física e Instituto de Química da Universidade de São Paulo.

Scientific literacy is a process that enables students to position themselves critically to scientific issues present in everyday life. In this regard, more to memorize terms and concepts, it is necessary to understand by the students of the role of science in society, as well as the aspects involved in the production of scientific knowledge.To promote this process of Scientific Literacy in the classroom is necessary that the activities proposed to students propitiate time to develop own skills of scientific work. According Sasseron and Carvalho (2008) these skills occur in investigative activities and constitute Scientific Literacy Indicators, which were subsequently extended by Penha, Vianna and Carvalho (2009).Thus, this study aimed to investigate how are the experimental activities in the context of education by research promoting Scientific Literacy. The choice of experimental activity was given to the fact that many teachers believe this is an essential strategy for teaching science. For this purpose, an investigative trial class applied to students of the seventh grade of elementary school was analyzed and then was identified Scientific Literacy Indicators present in this activity as well as the frequency with which these indicators appear at each stage of class proposal. The results showed that the experimental activity in the context of education for research, enabled students to develop, in addition to the proposed skills by Sasseron and Carvalho (2008) and Penha, Viana and Carvalho (2009), another skill required in individual training literate scientifically, thus creating an environment conducive to the development of specific skills. In this way, the presence of Scientific Literacy indicators in the research experimental activity is directly related to the way the activity is structured by teachers. Moreover, in science classes, to the understanding of a particular concept it is necessary to approach interdisciplinary concepts sometimes considered supporting the teachers, that when well worked in experimental class is critical to solving the problem proposed by the investigative activity.
\end{abstract}

Keywords: Literacy Scientific, Inquirid-based Science Teaching, Experimental Activit 


\section{SUMÁRIO}

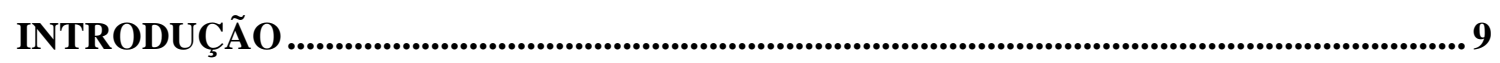

CAPÍTULO 1 - REFERENCIAL TEÓRICO..................................................................... 12

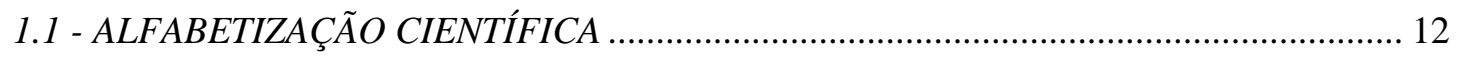

1.2 - ENSINO DE CIÊNCIAS POR INVESTIGAÇÃO ………………………………….... 14

1.3 - AS ATIVIDADES PRÁTICAS E O ENSINO DE CIÊNCIAS.......................................... 17

CAPÍTULO 2 - METODOLOGIA..................................................................................... 21

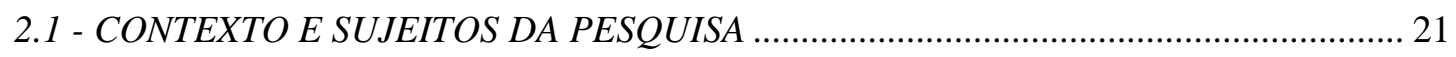

2.2 - O CONTEÚDO ABORDADO NA AULA: PLANTAS REALIZAM O PROCESSO DE FOTOSSÍNTESE E DE RESPIRAÇÃO CELULAR……………………………………... 22

2.3 - A AULA EXPERIMENTAL ………………………………..................................... 23

2.4 - TRATAMENTO DOS DADOS ……………………………………………… 25

2.5 - INDICADORES DE ALFABETIZAÇÃO CIENTÍFICA …………………………….... 26

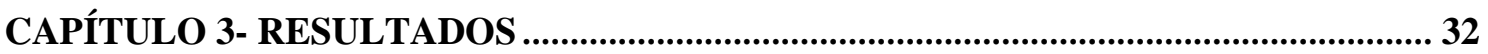

3.1 - ETAPA 1: LEVANTAMENTO DE CONHECIMENTOS PRÉVIOS .................... 32

3.2 - ETAPA 2: MANIPULAÇÃO DO MATERIAL E MONTAGEM DO

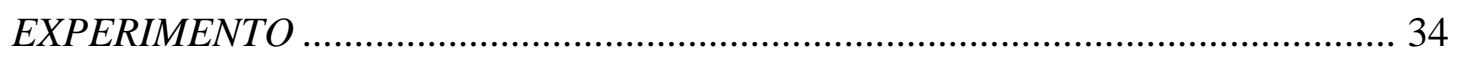

3.3 - ETAPA 3: INTERPRETAÇÃO E DISCUSSÃO DOS RESULTADOS DO

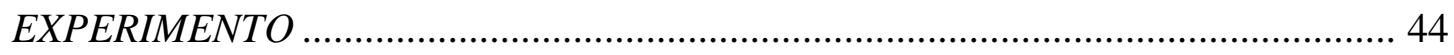

CAPÍTULO 4 - ANÁLISES E DISCUSSÕES ................................................................. 65

CONSIDERAÇÕES FINAIS ........................................................................................ 72

REFERÊNCIAS................................................................................................................. 74

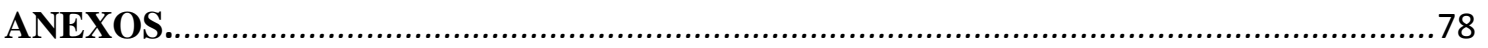




\section{INTRODUÇÃO}

Vivemos em uma época em que a Ciência e a Tecnologia estão cada vez mais presentes no dia a dia das pessoas. Assuntos como organismos geneticamente modificados, clones, células troncos, aquecimento global, alimentos orgânicos, animais em extinção e tantos outros estão presentes na mídia constantemente. Uma análise crítica sobre estes assuntos requer conhecimentos em Ciências, sem os quais uma avaliação sobre os mesmos podem ser insuficientes ou nem sequer ser realizada. Dessa forma a compreensão do conhecimento cientíco é fundamental para que os indivíduos interpretem o mundo e atuem como cidadãos conscientes na sociedade em que estão inseridos.

Nesse sentido o ensino de ciências deve capacitar os estudantes para participar de forma esclarecida e responsável das questões que envolvem o conhecimento científico e assim exercer de forma plena sua cidadania.

Para atender a essa demanda, o domínio conceitual de termos, conceitos, leis e teorias científicas não devem ser a única prioridade. Muitos pesquisadores apontam que as aulas de ciências devem propiciar um conhecimento sobre como o cientista procede na construção do conhecimento científico, e também estabelecer a relação deste conhecimento com a tecnologia, sociedade e meio ambiente. As aulas de ciências teriam então, o objetivo de alfabetizar cientificamente os alunos (SASSERON; CARVALHO, 2011).

Jiménez-Aleixandre (2004), afirma que um indivíduo alfabetizado cientificamente é capaz de compreender os fenômenos que acontecem ao seu redor, de saber relacionar esses fenômenos com suas possíveis causas científicas, como também de avaliar possibilidades de intervenção e de tomar decisões alicerçadas nos valores de um contexto social.

Todavia, Cachapuz et al. (2005), revelam que o foco do ensino ainda é a memorização de leis e conceitos, e que a Ciência continua sendo abordada como um conhecimento neutro, inquestionável, e desvinculado do contexto social vigente no momento da sua produção.

Os objetivos do ensino de ciências praticados atualmente nas escolas não convergem, portanto, para a formação de alunos alfabetizados cientificamente. Há então 
um desafio, que consiste no planejamento de ambientes de aprendizagem que viabilizem a Alfabetização Científica.

Uma estratégia didática muito empregada no ensino de ciências é o uso de atividades experimentais. Pesquisadores e professores apontam como imprescindível sua utilização no ambiente escolar. Muito dessa importância é atribuída à constatação de que atividades experimentais motivam os estudantes e facilitam a aprendizagem dos conceitos científicos. Contudo, este entendimento carece de uma reflexão sobre como tais estratégias ajudam a melhorar a aprendizagem de Ciências em sala de aula. Na maioria das vezes, as aulas baseadas em atividade experimentais se limitam à manipulação de materiais e não há espaço para o exercício reflexivo.

Praia, Cachapuz e Gil-Pérez (2002) assinalam que as atividades experimentais propostas pelos livros didáticos sugerem uma perspectiva empirista, focada nos resultados finais, independentemente dos processos da sua obtenção. Nesta perspectiva não há espaço para a problematização e não são abordados outros pontos mais complexos da pesquisa nem as condições teóricas e técnicas envolvidas na produção.

Carvalho (2007) complementa afirmando que as experiências, quando existem, se reduzem a uma receita, o chamado método científico. Segundo a autora, as experiências deveriam ser planejadas para que os alunos resolvessem um problema procurando uma resolução e uma explicação, quando então possibilitariam a presença de alguns aspectos culturais e motivacionais no ensino de ciências.

Em concordância com Praia, Cachapuz e Gil-Pérez (2002) e Carvalho (2007) tais atividades apresentam uma visão distorcida de como a ciência produz conhecimento, uma vez que as aulas apresentam sempre roteiros fechados com foco no resultado final e não processo de obtenção de tais resultados.

Quando se almeja um ensino que dê condições para os alunos se alfabetizarem científicamente faz-se necessário planejar e executar atividades experimentais que privilegiem a participação dos alunos. Quando as atividades experimentais estão direcionadas a valorizar o processo de coleta de dados, observação, levantamento de hipóteses, propor soluções, explora-se mais as suas habilidades cognitivas. (CARVALHO, 2007)

O ensino por investigação é tido por muitos autores (ZÔMPERO; LABURU, 2011) como uma proposição de ensino que favorece o engajamento dos estudantes em atividades que se aproximam da atividade científica. Dessa forma, aplicar as propostas 
do ensino por investigação na realização de atividades experimentais possibilitaria aos alunos exercitar um modo de pensar e realizar explicações que são próprios da Ciência.

A partir das colocações anteriores, nossa pesquisa busca responder: Como são as aulas experimentais, no contexto do ensino por investigação, que promovem a Alfabetização Científica?

O objetivo do presente trabalho é identificar indicadores de Alfabetização Científica presentes em uma aula experimental investigativa sobre fotossíntese e respiração celular para o ensino fundamental. Temos também, como objetivos específicos:

- Identificar e descrever as etapas da aula experimental;

- Relacionar os indicadores com a etapa em que ocorrem.

Este trabalho divide-se em quatro capítulos. O primeiro capítulo consiste em referencial teórico que embasa toda a pesquisa, com abordagens em Alfabetização Científica, o Ensino por Investigação e Aulas Práticas Experimentais. O segundo capítulo refere-se à metodologia, onde se apresenta todas as etapas da construção dos dados da pesquisa. O terceiro capítulo descreve os resultados obtidos. No quarto capítulo fazemos a discussão dos nossos resultados e por fim no último capítulo, trazemos as considerações finais do trabalho. 


\section{CAPÍTULO 1 - REFERENCIAL TEÓRICO}

\section{1 - ALFABETIZACÃO CIENTÍFICA}

É perceptível na sociedade atual a influência do conhecimento científico nas mais diversas áreas. Diante deste panorama, em que a todo momento temos que nos posicionar ante as questões científicas, o ensino de Ciências não pode estar alheio a essas questões. Nesse contexto está inserido o termo Alfabetização Científica, uma proposição de ensino que tem como objetivo oferecer condições para que os alunos possam atuar conscientemente e criticamente na sociedade perante um assunto que envolve o conhecimento científico (SASSERON;CARVALHO, 2008).

Sendo assim, a Alfabetização Científica entende que o ensino não pode e não deve se limitar a memorização de termos e conceitos científicos. É fundamental que os estudantes compreendam os fatores envolvidos na produção do conhecimento científico, bem como a relação existente entre este conhecimento, a sociedade, a tecnologia, e meio ambiente (AULER; DELIZOCOV, 2001; SASSERON;CARVALHO, 2008).

O termo Alfabetização Científica é uma tradução do termo em inglês Scientific Literacy, cunhado em 1958 nos Estados Unidos da América.

A tradução do termo Scientific Literacy para o português acabou gerando diferentes termos, essa variação advém da maneira particular com que cada um dos autores entende esse processo. Encontramos na literatura nacional, além do termo Alfabetização Científica, os termos Letramento Científico e Enculturação Científica.

Mamede e Zimmermann (2005) empregam o termo "Letramento Científico" para definir um ensino em que o indivíduo consiga utilizar o conhecimento científico e tecnológico no seu cotidiano, opinando de forma consciente sobre assuntos que demandam este conhecimento.

Carvalho e Tinoco (2006) argumentam que o ensino de ciências precisa inserir os alunos na cultura científica, daí o termo "Enculturação Científica". Para as autoras, é fundamental que os alunos entrem em contato com o universo científico, que possui peculiaridades no que tange, por exemplo, os modos de produção e a linguagem utilizada. As autoras ressalvam que a enculturação científica pode ser muito bem conciliada com a cultura de origem, não havendo necessidade de ignora-lá ou abandonalá. 
Já o termo Alfabetização Científica, que optamos usar neste trabalho, tem como base as ideias de Alfabetização cunhadas por Paulo Freire (1980 apud SASSERON; CARVALHO, 2011. p. 61). “[...] a alfabetização é mais do que o simples domínio psicológico e mecânico de técnicas de escrever e ler. É o domínio destas técnicas em termos conscientes". Dessa forma, o aluno alfabetizado cientificamente consegue ir além das habilidades escritora e leitora, ele possui a capacidade de pensar de forma lógica e racional e participar de maneira crítica e consciente dos assuntos que envolvem o conhecimento científico.

Essa variação semântica também ocorre na literatura internacional, onde encontramos a expressão inglesa "Scientific Literacy" traduzida como "Alphabétisation Scientifique" na língua francesa. Já na língua espanhola, o termo utilizado é "Alfabetización Científica."

Apesar da pluralidade semântica existente sobre o termo, uma extensa revisão bibliográfica foi realizada por Sasseron e Carvalho (2011) apontando que todas as definições convergem para um ensino de Ciências que almeja formar um sujeito crítico e capaz de entender o mundo a sua volta. As autoras encontraram pontos de convergência que permitiu a elaboração de três eixos que estruturam a Alfabetização Científica:

$\checkmark \quad$ O primeiro desses três eixos estruturantes refere-se à compreensão básica de termos, conhecimentos e conceitos científicos fundamentais. Por este eixo, os alunos entendem a construção dos conhecimentos científicos e conceitoschave que permitem compreender informações variadas presentes no cotidiano;

O segundo eixo preocupa-se com a compreensão da natureza das ciências e dos fatores éticos e políticos que circundam sua prática. Este eixo atribui à ciência um campo do conhecimento que está em constante transformação e que possui um caráter histórico o que possibilita uma reflexão por parte dos alunos sobre a produção científica;

O terceiro eixo estruturante da Alfabetização Científica compreende o entendimento das relações existentes entre ciência, tecnologia, sociedade e meio-ambiente. Este eixo possibilita os alunos compreender as aplicações e implicações das descobertas científicas na sociedade, sendo assim capazes de atuarem na construção de um planeta sustentável. 
Contemplar esses eixos nas aulas de Ciências aproxima o aluno da produção do conhecimento científico, permitindo a sua utilização nas mais distintas ocasiões, dentro e fora de sala, seja lendo um texto que aborda assuntos da ciência ou mesmo argumentando em situações cotidianas (SASSERON, 2008).

Sasseron e Carvalho (2008) apontam para a necessidade de ações em sala de aula que promovam a Alfabetização Científica dos alunos, destacando que a aprendizagem de Ciências depende de um envolvimento ativo e reflexivo dos alunos.

Diante do exposto, percebe-se que é imperiosa a execução de ações que promovam o processo de Alfabetização Científica em sala de aula e aproxime o aluno da Cultura Científica.

\section{2 - ENSINO DE CIÊNCIAS POR INVESTIGAÇÃO}

A Ciência caracteriza-se por um corpo de conhecimento composto por leis, teorias, conceitos e princípios que são produzidos a partir de uma metodologia investigativa. Esta metodologia envolve o desenvolvimento de habilidades técnicas, tais como a montagem e uso de equipamentos, habilidades de investigação, como elaborar hipóteses, fazer previsão, organizar informações, planejar experimentos, criar modelos e também habilidades de comunicação como a divulgação e apresentação dos dados.

Dentro da perspectiva da Alfabetização Científica em que o conhecimento científico deve ir além dos produtos da Ciência, o ensino de Ciências deve aproximar os estudantes dos modos de produção da Ciência, ou seja, muitas das características do trabalho dos cientistas devem estar presentes nas salas de aula.

Cabe salientar que o objetivo não é formar miniaturas de cientistas, mas sim envolver os estudantes em práticas que são peculiares à construção do conhecimento científico, possibilitando que estes aprendem a pensar científicamente (CAPECCHI; CARVALHO, 2006).

Nesse contexto está inserido o ensino por investigação. Uma abordagem de ensino que se opõe às propostas de ensino tradicional, prioritariamente de cunho expositivo, em que o professor é um mero transmissor de conhecimentos e os alunos são receptores. Na proposta investigativa, aspectos inerentes á produção do conhecimento científico são desenvolvidos em sala de aula (CARVALHO et al., 2013). 
A proposta de um ensino por investigação não é algo recente, já no início do século XX encontramos autores que indicavam que essa era uma estratégia a ser adotada no ensino. Contudo essa abordagem de ensino apresentou características e objetivos distintos, que estavam diretamente relacionados com o momento histórico, político e social vigente (ZÔMPERO; LABURU, 2011).

Trópia (2011) discorre sobre como a perspectiva do ensino por investigação se apresentou ao longo do tempo, e afirma que já no início do século XX Jown Dewey propunha a inserção da investigação no ensino; Os problemas sociais enfrentados no começo do século influenciaram Dewey, que considerava que o desenvolvimento de atividades investigativas nas escolas, baseadas no método científico seria capaz promover o desenvolvimento social.

Já nas décadas de 50 e 60 Trópia (2011) pontua que a investigação foi incluída em sala de aula com a intenção de promover o desenvolvimento científico, econômico e tecnológico. O lançamento do Sputinuk I pelos soviéticos em 1957 foi um evento que marcou a busca pelo desenvolvimento tecnocientífico pelos países. O objetivo era formar cientistas. Nesse sentido a busca pelo desenvolvimento tecnológico e econômico refletiu diretamente no ensino de Ciências. Os alunos deveriam fazer ciência. Para isso foram desenvolvidos kits de experimentação em que os alunos realizavam experimentos com etapas bem definidas, de observação, coleta de dados, análise de resultados. As atividades possuíam um caráter mecânico e comprobatório, o importante era a vivência do método científico. (KRASILCHIK,2000)

As escolas recebiam kits, que também podiam ser comprados pela população. Houve um grande investimento em infraestrutura com a construção e montagem de laboratórios nas escolas. Krasilchik (2000) deixa claro que a proposta investigativa realizada considerava a Ciência como uma ciência neutra e descontextualizada; o trabalho científico era visto como um cumprir etapas pré-determinadas.

A partir da década de 1980 até os dias atuais, as pesquisas em ensino de ciências trouxeram um novo enfoque para o ensino investigativo em sala de aula; Documentos como o Science For All Americans produzido nos Estados Unidos da America e o National Science Education Standards elaborado na Inglaterra orientava para o desenvolvimento de um ensino que capacitasse os estudantes a participarem das discussões envolvendo ciência e tecnologia que começaram a emergir na sociedade (BARROW, 2006). Sob esta nova óptica o ensino por investigação vai além do conhecimento do método científico, aspectos referentes à produção do conhecimento 
científico também são demandados para que os estudantes consigam avaliar e se posicionar diantes das questões científicas.

Zômpero e Laburú (2011) assinalam que existem diferentes entendimentos sobre a maneira que este ensino deva ocorrer em sala de aula.

Munford e Lima (2007) também discorrem sobre os diferentes entendimentos no que tange a execução das atividades investigativas. As autoras pontuam alguns aspectos que consideram haver um entendimento equivocado em relação á proposta investigativa. Quanto à proposição do problema, por exemplo, as autoras sinalizam que muitas pessoas acreditam que este deve partir do aluno, ficando a cargo do mesmo selecionar o objeto de estudo e elaborar todo o processo de planejamento da investigação; As autoras defendem que este grau de autonomia deve ser avaliado pelo professor e deve estar de acordo com a faixa etária dos estudantes e do nível de ensino em que os mesmos se encontram. Para as autoras à proposição do problema, também pode ser feita pelos professores, ficando a cargo destes avaliarem o grau de autonomia que dará aos estudantes, levando em conta a faixa etária dos estudantes e o nível de ensino em que os mesmos se encontram. Em consonância com as considerações de Munford e Lima (2007), o trabalho de Carvalho (2006) apresenta o que ela chama de níveis de participação dos alunos nas atividades investigativas. Os níveis vão de I a V e são denominados pela autora como graus de liberdade. A autonomia do aluno vai ficando cada vez maior conforme vai aumentanto o grau de liberdade.

Munford e Lima (2007) também pontua o fato de apenas as atividades experimentais serem consideradas de caráter investigativo. Segundo as autoras a proposta investigativa não se limita a atividade experimental; e também muitas vezes uma atividade experimental pode não ser investigativa.

Uma vez que este trabalho analisa uma atividade experimental, é coerente pontuarmos essas diferenças tal como fez Fernanda Bassoli (2014, p.583) em seu artigo

\footnotetext{
“As atividades investigativas se caracterizam pela resolução de um problema e pela oportunidade dos alunos refletirem. Já as atividades experimentais investigativas estão inseridos nesta perspectiva de ensino, contudo são imprescindívelmente experimentais".
} 
Apesar dos diferentes entendimentos em relação à maneira que as atividades investigativas devam ser executadas em sala de aula, é possível encontrar pontos de convergência que permite caracterizar tais atividades.

\footnotetext{
Apesar da polissemia associada ao termo atividades de investigação e da falta de consenso quanto às peculiares que as referidas atividades apresentam, admitimos que algumas características devem estar presentes nas atividades investigativas:o engajamento dos alunos para realizar as atividades; a emissão de hipóteses, nas quais é possível a identificação dos conhecimentos prévios dos mesmos; a busca por informações, tanto por meio dos experimentos, como na bibliografia que possa ser consultada pelos alunos para ajudá-los na resolução do problema proposto na atividade; a comunicação dos estudos feitos pelos alunos para os demais colegas de sala, refletindo, assim, um momento de grande importância na comunicação do conhecimento, tal como ocorre na Ciência, para que o aluno possa compreender, além do conteúdo, também a natureza do conhecimento científico que está sendo desenvolvido por meio desta metodologia de ensino." (ZÔMPERO E LABURÚ , 2011 p.79)
}

\section{3 - AS ATIVIDADES PRÁTICAS E O ENSINO DE CIÊNCIAS}

Um tema com grande destaque nas pesquisas em Ensino de Ciências bem como na comunidade escolar é a utilização das atividades práticas como estratégias de ensino.

No ideário dos professores tais atividades são consideradas imprescindíveis e tidas como a representação de uma boa aula de Ciências, como ilustra a pesquisa de Ramos e Rosa (2008), em que professores afirmam que os alunos aprendem mais quando realizam as atividades práticas, apesar de nunca terem realizado essas atividades com seus alunos; e o trabalho de Galliazzi, et al., (2001), onde participantes de um curso de formação para professores de química creditam grande importância às atividades experimentais sem nunca questioná-las.

Hodson (1994) alerta que muitos dos aspectos positivos sobre as atividades práticas carecem de uma reflexão da sua real função nos processos de ensino e aprendizagem e como consequência, a execução destas atividades são muitas vezes confusas e de baixo valor educacional. Segundo este mesmo autor essa reflexão deve iniciar-se já na utilização dos termos empregados para definir essa estratégia de ensino. 
Termos como atividades práticas, experimentos, atividades experimentais, são muitas vezes utilizados e entendidos como sinônimos, entretanto nem sempre se referem ao mesmo tipo de atividade.

Encontramos na literatura autores como Hodson (1994), Raboni (2002) Filho (2001) que consideram atividades práticas uma modalidade de ensino em que há a participação ativa dos alunos, podendo esta ser um trabalho de campo, observações, vídeos ou filmes em que os alunos realizam registros, confecções de pôsteres, análises de tabelas e gráficos, trabalhos laboratoriais, demonstrações, análise de histórias em quadrinhos.

Observamos que a definição de atividade prática apresentada por esses autores tem como cerne o envolvimento ativo dos estudantes na atividade. Existe, porém outros entendimentos, como o apresentado por Krasilchik (2004) para quem aulas práticas são aquelas que permitem aos alunos terem contato direto com os fenômenos, manipulando materiais e equipamentos para obtenção de dados. Já as demonstrações e simulações são entendidas como tipos de modalidades didáticas e não como aula prática. Para Hodson (1994) o que Krasilchik (2004) define como aula prática, é um tipo específico de atividade prática definida por ele como atividade experimental. Atividades em que na sua execução, ocorre a precisão de medidas e o controle de variáveis de forma similar na Ciência.

Assim como Hodson (1994), Raboni (2002), Filho (2001) entendemos que as atividades práticas englobam toda postura ativa do aluno na construção do conhecimento. E compartilhamos também da definição de atividades práticas experimentais proposta por Hodson (1994). Atividades caracterizadas por serem realizadas no laboratório ou mesmo numa sala de aula que apresente condições de segurança para a realização das mesmas, abrangendo a manipulação de materiais e o controle de variáveis.

O foco do nosso trabalho está nas atividades práticas experimentais, na maneira como tais atividades são organizadas e conduzidas e a relação destas com o processo de ensino aprendizagem.

Andrade e Massabni (2011) apontam que muitos professores não realizam atividades experimentais por falta de tempo, falta de equipamentos, insegurança para realizar este tipo de trabalho com os alunos. Neste mesmo trabalho os autores argumentam que a não execução de atividades é também um indicativo das concepções 
de ensino de Ciências que aquele professor possui; não considerando relevante para o aprendizado as atividades experimentais.

Segundo a literatura (AXT,1991; SILVA ; ZANON,2000; CARVALHO,2006) as atividades experimentais quando existem são ministradas de forma mecânica e superficial, os alunos cumprem etapas pré-determinadas, semelhante a execução de uma receita, com o simples objetivo de comprovar os estudos teóricos.

Nesse sentido as atividades experimentais praticadas em sala de aula conduzem para uma visão distorcida da produção do conhecimento científico e vai na contra mão da proposta realizada pelo Parâmetro Curricular Nacional para o Ensino de Ciências (1998) que orienta:

[...] "É muito importante que as atividades não se limitem a nomeações e manipulações de vidrarias e reagentes, fora do contexto experimental. É fundamental que as atividades práticas tenham garantido o espaço de reflexão, desenvolvimento e construção de idéias, ao lado de conhecimentos de procedimentos e atitudes". (BRASIL,1998 P.122)

As pesquisas em Ensino de Ciências tem divulgado que as atividades experimentais demandam outro enfoque, de maneira a assumir um caráter investigativo. Nessa perspectiva, as atividades práticas ofereceriam um desafio cognitivo aos alunos, que deveriam realizar conexões entre as atividades propostas e os conhecimentos conceituais relacionados. $\mathrm{O}$ professor exerceria o papel de mediador da aprendizagem.

Nesse sentido Gil Perez e Castro (1996) ressalvam que as características das atividades experimentais investigativas devem ser pontuadas e esclarecidas, caso contrário o termo atividades experimentais investigativas corre o risco de ser apenas um slogan, que não provocará nenhuma alteração nas práticas realizadas tradicionalmente. Os autores trazem então em seu trabalho aspectos que consideram importantes para a concretização de uma aula experimental investigativa. Não se trata de etapas a serem cumpridas de forma linear, e sim uma maneira de apresentar a riqueza do trabalho científico que pode ser contemplado em aulas experimentais investigativas: 1) Situação problemática aberta; 2) Favorecer a reflexão dos estudantes sobre o objeto de estudo; 3 ) Potencializar as ánalises qualitativas de forma a entender e solucionar os problemas; 4) Elaborar hipóteses; 5) Potencializar a elaboração de modelos e de desenhos experimentais pelos alunos; 6) Interpretar os resultados, 7) Relação do experimento com 
a sociedade; 8) Integração do conhecimento com outros campos do conhecimento; 9) Ressaltar a importância da comunicação e do debate científico; 10) Potencializar a dimensão coletiva do trabalho científico.

Carvalho et al., (2013) assim como Gil Perez e Castro (1996) apresentam características que consideram importantes para a efetivação de uma atividade experiemental investigativa. Conter um problema; Ser, sempre que possível, generativas, ou seja, devem desencadear debates, discussões, outras atividades experimentais ou não; Propiciar o desenvolvimento de argumentos, por meio de coordenação de enunciados teóricos e evidências, bem como considerar a multiplicidade de pontos de vista em disputa ou a serem coordenados; Motivar e mobilizar os estudantes, promover o engajamento destes com o tema em investigação. Desafios práticos e resultados inesperados podem auxiliar nessa direção; Propiciar a extensão dos resultados encontrados a todos os estudantes da turma.

A partir das proposições acima podemos inferir que as atividades experimentais investigativas vão além da manipulação de materiais, para, além disso, os alunos tem uma ação reflexiva os conceitos científicos e sobre a produção do conhecimento na Ciência. 


\section{CAPÍTULO 2 - METODOLOGIA}

O presente trabalho utilizou-se de uma abordagem qualitativa para a análise dos dados. A opção por tal abordagem deve-se ao fato das pesquisas qualitativas terem como premissas que, um fenômeno pode ser mais bem compreendido no contexto em que ocorre e do qual é parte, devendo, portanto ser analisado de forma integrada. Pela abordagem qualitativa a ação humana tem sempre um significado, que não pode ser apreendido somente do ponto de vista quantitativo e objetivo (GODOY, 1995). Vale ressalvar que a escolha por uma abordagem qualitativa não anula a importância das pesquisas quantitativas que por meio das análises estatísticas podem detalhar o comportamento do objeto. Contudo, neste trabalho, os dados analisados buscam mostrar ações dos alunos diante de um problema proposto pelo professor em uma aula experimental, por isso todos os elementos que envolvem essa situação precisam ser detalhados.

\section{$\underline{2.1 \text { - CONTEXTO E SUJEITOS DA PESQUISA }}$}

Os dados que compõem esta pesquisa procedem da gravação de áudio e vídeo de uma aula experimental investigativa aplicada aos alunos do $7^{\circ}$ ano de escola municipal do interior de São Paulo. A turma é composta por vinte e nove alunos, entre onze e treze anos. Para a realização da atividade os alunos foram dividos em cinco grupos com seis integrantes em média.

A atividade teve duração de 100 minutos divididos em duas aulas de 50 minutos cada, sendo que a primeira teve início às 7:50 h e terminou às 8:40 h e a segunda teve início às 11:30 h e terminou às 12:20 h.

As aulas foram gravadas com uma câmera de vídeo colocada no canto esquerdo da sala de modo a focar o maior número de alunos. Toda a gravação foi transcrita integralmente e procurou-se reproduzir de forma fidedigna todas as falas dos alunos e professores. As transcrições formam a única fonte de dados do trabalho, portanto, analisamos apenas a produção oral dos sujeitos da pesquisa.

As aulas foram planejadas e ministradas por três estudantes universitários, que integram o projeto de iniciação a docência PIBID (Programa Institucional de Bolsa de Iniciação á Docência). Este programa, presente em vários estados da federação, tem 
como objetivo valorizar a profissão docente, incentivando os estudantes universitários atuarem na educação básica. Especificamente, os estudantes integram o Subprojeto desenvolvido na Faculdade de Filosofia Ciências e Letras de Ribeirão Preto. O foco do projeto é o ensino de Ciências na perspectiva da Alfabetização Cientifica e busca analisar a importância do uso de elementos da cultura científica em sala de aula. Dentre as atividades desenvolvidas destacamos o estudo e a elaboração de sequências de atividades pautadas no ensino por investigação, que auxiliam os alunos a compreenderem não apenas conceitos e termos chaves da ciência, mas a natureza do fazer científico.

\section{2 - O CONTEÚDO ABORDADO NA AULA: PLANTAS REALIZAM O PROCESSO DE FOTOSSÍNTESE E DE RESPIRAÇÃO CELULAR}

A aula experimental investigativa, objeto de estudo desta pesquisa, faz parte de uma extensa sequência didática que aborda as características dos seres vivos. A aula analisada neste trabalho compõe uma sequência de atividades que abordam uma das características dos seres vivos, a necessidade de energia pelos seres vivos. Nesta atividade, o objetivo foi o de levar os alunos a reconhecerem que as plantas realizam os processos de fotossíntese e de respiração, para obtenção de energia.

Kawasaki e Bizzo (2000) apontam que, muitos estudantes apresentam concepções erradas sobre o processo de fotossíntese. Muitos consideram fotossíntese e respiração processos contrários e afirmam que as plantas realizam fotossíntese e os animais realizam respiração, quando, na verdade, ambos respiram e apenas os vegetais realizam o processo de fotossíntese.

Com o objetivo de que os alunos compreendessem os processos de fotossíntese e respiração celular, os professores propuseram a execução de um experimento.

No experimento é possível verificar de modo indireto e não quantitativo a produção de $\mathrm{CO}_{2}$ pelos vegetais. Em ambientes em que a produção fotossintética é menor que a de respiração este gás é liberado no ambiente, e em contato com a solução de vermelho de cresol (um indicador de $\mathrm{pH}$ ) produz ácido carbônico que altera a cor deste indicador. Já, quando a taxa de fotossíntese é maior que a taxa de respiração, o consumo de gás carbônico é maior do que aquele produzido pela respiração, e as plantas retiram esse gás do meio ambiente. (JUNQUEIRA, 2014) 
Para a atividade, foram simulados dois ambientes: um no qual a taxa de fotossíntese é maior do que a taxa de respiração e outro na qual a taxa de fotossíntese foi menor em relação à taxa de respiração. No tubo em que a taxa de respiração foi maior do que a taxa de fotossíntese houve a alteração da cor do indicador de $\mathrm{pH}$.

Contrapondo-se a uma abordagem tradicional, cujas atividades experimentais possuem um caráter comprobatório, nesta atividade há um espaço para discussão dos dados obtidos onde a maior parte da aula consiste justamente em discussões mediadas pelos professores sobre os dados obtidos na atividade. Dentro do contexto da Alfabetização Científica, é muito importante esse tipo de enfoque para a atividade investigativa, dado que o conhecimento científico é apresentado aos alunos como uma construção social.

\section{3 - A AULA EXPERIMENTAL}

Os professores iniciaram a aula questionando aos alunos sobre o processo de fotossíntese e registraram as respostas na lousa. Em seguida, os alunos foram divididos em grupos. Cada grupo tinha disponível um tubo de ensaio com uma pequena quantidade da solução indicadora do $\mathrm{pH}$ (vermelho de cresol), material até então desconhecido por eles. Os professores convidaram os alunos a soprarem, com o auxílio de um canudo, dentro dos tubos de ensaio, o que fez o líquido mudar de cor. Seguiu-se a adição de vinagre e soda cáustica em tubos diferentes, ambos contendo o vermelho de cresol. As duas substâncias mudaram de cor, sendo que a cor do indicador de ph do tubo que continha vinagre ficou semelhante à cor do indicador dos tubos que os alunos sopraram. A partir dessa constatação, os alunos questionaram o fato de tanto o tubo onde foi colocado vinagre bem como os tubos que eles assopraram apresentarem a mesma cor. Os professores explicaram a reação entre o gás carbônico liberado no processo de expiração e a água contendo vermelho de cresol formando o ácido carbônico. Como a substância resultante é ácida assim como o vinagre, a solução indicadora apresenta a mesma cor para ambos.

Explorando ainda mais as reações entre as substâncias e o indicador de pH, os professores exibiram gelo seco aos alunos. A estes, foi informado que o gelo seco é constituído por gás carbônico em estado sólido. Neste momento, um aluno se antecipou aos professores sugerindo que o gelo seco fosse misturado ao vermelho de cresol. Antes 
de realizar a mistura, os professores questionaram aos alunos o que aconteceria e neste momento várias hipóteses foram levantadas, dentre elas o fato de ficar amarelo por se tratar de gás carbônico. Os professores adicionaram gelo seco ao vermelho de cresol e este ficou amarelo, comprovando a hipótese levantada pelo aluno. Pontuamos que essa generalização realizada pelos alunos é um indicativo de que eles entenderam como funciona um indicador ácido-base indo além da mera memorização. Finalizando esta etapa da aula, os alunos escreveram como funciona o indicador ácido-base.

Logo após, foi realizada a montagem do experimento. Cada grupo recebeu uma estante de madeira contendo três tubos de ensaio com aproximadamente $5 \mathrm{ml}$ de vermelho de cresol cada. Os tubos foram organizados da seguinte maneira:

Tubo 1: Foram colocadas dentro do tubo folhas recentemente coletadas de uma árvore. As folhas foram dispostas de maneira que não houvesse contato delas com o vermelho de cresol. O tubo foi tampado com papel filme e em seguida embrulhado no papel alumínio.

Tubo 2: Foram colocadas folhas de maneira semelhante à do Tubo 1, porém o tubo não foi coberto com papel alumínio.

Tubo 3: O tubo continha apenas vermelho de cresol, utilizado como um controle negativo, com o objetivo de comprovar que as alterações que viessem a ocorrer nos demais tubos decorreriam da relação com o material biológico ali presente.

Todos os tubos foram acomodados em uma estante maior e colocados próximos a uma lâmpada incandescente. Os tubos foram deixados próximos à luz até o horário de início da segunda aula. Quando os alunos retornaram para a sala, a primeira ação foi retirar o papel alumínio do Tubo 1, quando foi constatado que as cor da solução indicadora estava diferente daquela contida nos demais tubos. Mediante esta constatação, os professores instigaram os alunos a explicar o motivo da alteração da cor.

O problema que os alunos tinham que resolver era: Por que o indicador apresenta uma coloração diferente nos frascos em que as plantas ficaram em contato com a luz dos frascos em que as plantas não ficaram em contato com a luz? Para explicar a mudança ocorrida na solução de vermelho de cresol, os alunos retomaram as etapas de conhecimento prévio, de contato com o material e, de maneira interativa com o professor e com os outros alunos, chegaram à conclusão do experimento. Dessa forma, para fazer a relação da mudança de cor do indicador com os fenômenos de fotossíntese e respiração, os alunos tiveram que retomar as atividades de constatação realizadas anteriormente. 


\section{4 - TRATAMENTO DOS DADOS}

A primeira fase do trabalho foi dedicada à transcrição integral da aula, seguindo os pressupostos de Preti (2003).

A partir da leitura atenta da transcrição, foram identificadas três grandes etapas, que se referem a tarefas específicas realizadas durante a aula.

\footnotetext{
$\checkmark \quad$ Levantamento de conhecimentos prévios;

$\checkmark \quad$ Manipulação do material e montagem do experimento: Fase A- Entrando em contato com os materiais. Fase B- Resolvendo problemas envolvendo a utilização do material;

$\checkmark \quad$ Interpretação e discussão dos resultados do experimento.
}

Na etapa de Levantamento de Conhecimentos Prévios, os professores dedicamse a levantar concepções prévias dos alunos sobre o tema a ser trabalhado. Mortimer (2006) ressalva, em seu trabalho, a importância dos conhecimentos que os alunos trazem consigo na construção dos novos conhecimentos. Fundamentado na teoria de equilibração proposta por Piaget (1977 apud MORTIMER, 2006), Mortimer defende que os novos conceitos são aprendidos por meio de uma reestruturação dos conhecimentos que os alunos já possuem. Segundo o autor os conhecimentos prévios entram em conflito com os conhecimentos a serem aprendidos e a resolução deste conflito se dá quando os estudantes, a partir dos conhecimentos que possuem, estabelecem questionamentos que o levam a uma mudança conceitual. $\mathrm{O}$ mesmo autor no trabalho com Carvalho (MORTIMER, E. F.; CARVALHO, A. M. P. 1996), pontua que os conhecimentos prévios não precisam ser sempre modificados, ele pode servir para ampliar os conceitos que os alunos já possuem.

A etapa de Manipulação dos Materiais e Montagem do Experimento consiste no manuseio de tubos de ensaio e da substância química denominada vermelho de cresol, um indicador ácido-base. Nesta etapa, os alunos compreendem como age um indicador ácido-base e realizam a montagem do experimento, com o auxílio dos professores.

A etapa de Interpretação e Discussão dos Resultados dos Experimentos é o momento em que os alunos buscam estabelecer consenso sobre os resultados 
observados e os conceitos envolvidos. Destacamos que esta fase é marcada pela interação dialógica entre alunos-alunos e aluno-professor.

Determinadas as três etapas da aula, selecionou-se, para cada uma, episódios de interesse para a análise.

A ideia de episódio é uma adaptação da definição de evento na tradição da etnografia interacional, e se trata de um segmento do discurso com fronteiras claras em termos de conteúdo temático, fase didática ou tarefas desenvolvidas (MORTIMER et al., 2007). As fronteiras de um episódio são delimitadas por pistas contextuais verbais e não verbais, incluindo gestos, movimentos corporais dos participantes e as formas como estes se posicionam no espaço físico e interagem entre si e com os recursos materiais utilizados (SILVA; MORTIMER, 2010). As pistas verbais podem ser: mudança de tema, tópico da aula ou fase da atividade. Os episódios contextualizam as ações e o discurso produzido em sala de aula, por isso sua identificação ajuda a compreender o fluxo de interações discursivas de uma aula, possibilitando uma análise mais panorâmica da situação investigada (SILVA, 2008). Uma vez definidos os episódios, determinou-se os turnos de fala. Essa organização está representada no Quadro 1.

\begin{tabular}{|c|c|c|c|}
\hline Etapa & Episódios & Fase & Turnos \\
\hline $\begin{array}{c}1 \text { - Levantamento de } \\
\text { Conhecimentos } \\
\text { Prévios }\end{array}$ & 1 & & $6-30$ \\
\hline \multirow{5}{*}{$\begin{array}{c}2 \text { - Manipulação de } \\
\text { Materiais e } \\
\text { Montagem do } \\
\text { Experimento }\end{array}$} & \multirow{5}{*}{5} & Fase A & 32 ao 42 \\
\hline & & Fase A & 59 ao 63 \\
\hline & & Fase A & 71 ao 83 \\
\hline & & Fase A & 96 aо 102 \\
\hline & & Fase B & 114 ao 159 \\
\hline \multirow{2}{*}{$\begin{array}{c}3 \text { - Interpretação e } \\
\text { Discussão dos } \\
\text { resultados do } \\
\text { Experimento }\end{array}$} & \multirow[b]{2}{*}{2} & & 162 ao196 \\
\hline & & & 246 aо 386 \\
\hline
\end{tabular}

Quadro 1 - Divisão Macroscópica da aula analisada

\section{5 - INDICADORES DE ALFABETIZAÇÃO CIENTÍFICA}

Os Indicadores de Alfabetização Científica foram elaborados por Sasseron e Carvalho (2008) e são entendidos como habilidades necessárias a serem desenvolvidas nos estudantes com o intuito de promover a alfabetização científica. As autoras listam 
três grupos de indicadores: O primeiro grupo está diretamente relacionado ao trabalho com os dados durante uma investigação. São as atividades de Seriar, Organizar e Classificar Informações. O segundo grupo está relacionado à estruturação do pensamento. Neste grupo está o uso do raciocínio lógico e proporcional. Por fim, o último grupo reúne os indicadores relacionados à busca do entendimento da situação analisada. Fazem parte deste grupo os seguintes indicadores da Alfabetização Científica: levantamento de hipótese, teste de hipótese, justificativa, previsão, explicação.

O quadro a seguir indica quais indicadores são utilizados nas analises, bem como uma breve descrição dos mesmos:

\begin{tabular}{|c|c|}
\hline Indicador & Descrição \\
\hline Seriação de Informações & $\begin{array}{l}\text { Está ligada ao estabelecimento de bases para a } \\
\text { ação investigativa. Não prevê, } \\
\text { necessariamente, uma ordem que deva ser } \\
\text { estabelecida para as informações: pode ser } \\
\text { uma lista ou uma relação dos dados } \\
\text { trabalhados ou com os quais se vá trabalhar. }\end{array}$ \\
\hline Organização de Informações & $\begin{array}{l}\text { Surge quando se procura preparar os dados } \\
\text { existentes sobre o problema investigado. Este } \\
\text { indicador pode ser encontrado durante o } \\
\text { arranjo das informações novas ou já elencadas } \\
\text { anteriormente e ocorre tanto no início da } \\
\text { proposição de um tema quanto na retomada de } \\
\text { uma questão, quando ideias são relembradas. }\end{array}$ \\
\hline Classificação de Informações & $\begin{array}{l}\text { Aparece quando se buscam estabelecer } \\
\text { características para os dados obtidos. Por } \\
\text { vezes, ao se classificar as informações, elas } \\
\text { podem ser apresentadas conforme uma } \\
\text { hierarquia, mas o aparecimento desta } \\
\text { hierarquia não é condição sine qua non para a } \\
\text { classificação de informações. Caracteriza-se } \\
\text { por ser um indicador voltado para a ordenação } \\
\text { dos elementos com os quais se trabalha. }\end{array}$ \\
\hline Raciocínio Lógico & Compreende o modo como as ideias são \\
\hline
\end{tabular}




\begin{tabular}{|c|c|}
\hline & $\begin{array}{l}\text { desenvolvidas e apresentadas. Relaciona-se, } \\
\text { pois, diretamente com a forma como o } \\
\text { pensamento é exposto. }\end{array}$ \\
\hline Raciocínio Proporcional & $\begin{array}{l}\text { Assim como o raciocínio lógico, é o que dá } \\
\text { conta de mostrar o modo que se estrutura o } \\
\text { pensamento, além de se referir também à } \\
\text { maneira como as variáveis têm relações entre } \\
\text { si, ilustrando a interdependência que pode } \\
\text { existir entre elas. }\end{array}$ \\
\hline Levantamento de Hipóteses & $\begin{array}{l}\text { Aponta instantes em que são alçadas } \\
\text { suposições acerca de certo tema. Esse } \\
\text { levantamento de hipóteses pode surgir tanto } \\
\text { como uma afirmação quanto sob a forma de } \\
\text { uma pergunta (atitude muito usada entre os } \\
\text { cientistas quando se defrontam com um } \\
\text { problema). }\end{array}$ \\
\hline Teste de Hipóteses & $\begin{array}{l}\text { Trata-se das etapas em que as suposições } \\
\text { anteriormente levantadas são colocadas à } \\
\text { prova. Pode ocorrer tanto diante da } \\
\text { manipulação direta de objetos quanto no nível } \\
\text { das ideias, quando o teste é feito por meio de } \\
\text { atividades de pensamento baseadas em } \\
\text { conhecimentos anteriores }\end{array}$ \\
\hline Justificativa & $\begin{array}{l}\text { Aparece quando, em uma afirmação qualquer } \\
\text { proferida, lança-se mão de uma garantia para } \\
\text { o que é proposto. Isso faz com que a } \\
\text { afirmação ganhe aval, tornando-a mais segura. }\end{array}$ \\
\hline Previsão & $\begin{array}{l}\text { Este indicador é explicitado quando se afirma } \\
\text { uma ação e/ou fenômeno que sucede } \\
\text { associado a certos acontecimentos. }\end{array}$ \\
\hline Explicação & $\begin{array}{l}\text { Surge quando se buscam relacionar } \\
\text { informações e hipóteses já levantadas. } \\
\text { Normalmente a explicação é acompanhada de } \\
\text { uma justificativa e de uma previsão, mas é } \\
\text { possível encontrar explicações que não } \\
\text { recebem essas garantias. Mostram-se, pois, }\end{array}$ \\
\hline
\end{tabular}


explicações ainda em fase de construção que certamente receberão maior autenticidade ao longo das discussões.

Quadro 2 - Indicadores de Alfabetização Científica propostos por Sasseron e Carvalho (2008)

A luz dos nossos dados, os indicadores de Alfabetização Científica propostos por Sasseron e Carvalho (2008), foram insuficientes para analisarmos a atividde. Dessa forma utilizamos também um dos Indicadores de Alfabetização Científica Procedimentais proposto por Penha, Carvalho e Vianna (2009). Os Indicadores de Alfabetização Científica Procedimentais foram criados com o intuito de ampliar aqueles propostos por Sasseron e Carvalho (2008) e estão relacionados às atitudes apresentadas pelos estudantes durante a atividade investigativa. No nosso trabalho, identificamos a presença do indicador procedimental "Aquisição de dados" que, segundo os mesmos autores, está relacionado ao delineamento metodológico para a aquisição de dados durante a investigação.

\begin{tabular}{|l|l|l|}
\hline $\begin{array}{l}\text { Indicadores } \\
\text { Procedimentais } \\
\text { (ou de }\end{array}$ & $\begin{array}{l}\text { Aquisição de } \\
\text { Dados }\end{array}$ & $\begin{array}{l}\text { Relacionado ao delineamento metodológico necessário para } \\
\text { aquisição dos dados da investigação }\end{array}$ \\
\cline { 2 - 3 } & $\begin{array}{l}\text { Identificação de } \\
\text { Variáveis }\end{array}$ & $\begin{array}{l}\text { Estão relacionados com a elaboração de estratégias, } \\
\text { estruturas e procedimentos com o objetivo de identificar, } \\
\text { reconhecer e separar as variáveis que estão relacionadas } \\
\text { com } \\
\text { a situação em estudo. }\end{array}$ \\
\cline { 2 - 3 } & $\begin{array}{l}\text { Análise das } \\
\text { Relações entre } \\
\text { Variáveis }\end{array}$ & $\begin{array}{l}\text { Desenvolvimento de estratégias que possam explicitar e/ou } \\
\text { estabelecer relações de dependência qualitativas e/ou } \\
\text { quantitativas entre as diferentes variáveis identificadas }\end{array}$ \\
\hline
\end{tabular}

Quadro 3: Indicadores de Alfabetização Científica Procedimentais proposto por Penha, Carvalho e Vianna (2009)

Além dos indicadores de Alfabetização Científica presentes na literatura, neste trabalho também propomos o acréscimo de um indicador de Alfabetização Científica, denominamos este novo indicador como Constatação.

Atribuimos a criação deste indicador as peculiaridades desta atividade experimental. Enquanto analisávamos nossa atividade, observamos que na etapa 
manipulação e montagem do experimento, os alunos estabeleciam um contato sensorial com o indicador de $\mathrm{pH}$ (vermelho de cresol) utilizado no experimento. E chegavam a consensos sobre como aquela substância atuava. Observamos também, que as conclusões obtidas nesta etapa eram retomadas na etapa seguinte, enquanto discutiam os resultados do experimento. Inicialmente classificamos estes turnos de fala como organização e classificação de informações, contudo de acordo com Sasseron e Carvalho (2008), estes indicadores ... "está ligado ao estabelecimento de bases para a ação investigativa... Surge quando se procura preparar os dados existentes sobre o problema investigado; e ... "Aparece quando se buscam estabelecer características para os dados obtidos". Como este momento é anterior a ação investigativa não poderíamos utilizá-los para classificar esses turnos, contudo considerávamos um momento importante da aula que também não podia ser negligenciado.

Nesse sentido nos debruçamos sobre a literatura para tentarmos compreender e classificar estes momentos específicos da aula. Encontramos o trabalho de uma pesquisadora mexicana chamada Maria Guadalupe Moreno Bayardo.

Moreno (2002) em seu trabalho com estudantes de pós graduação, ou seja, com futuros pesquisadores, aponta que estes, apesar do longo período de escolaridade, apresentam um déficit de habilidades necessárias para a pesquisa. Segundo a autora, a formação de pesquisadores demanda o desenvolvimento de habilidades, hábitos e atitudes. A partir dessa constatação, a autora, juntamente com pesquisadores que trabalham com a formação de pós-graduandos, elaborou um conjunto de habilidades que julgam necessárias para a formação destes estudantes. A autora afirma que tais habilidades deveriam ser desenvolvidas durante todo o processo de escolarização. $\mathrm{O}$ conjunto de habilidades é dividido em núcleos e cada núcleo é composto por determinadas habilidades. Os núcleos são: Núcleo A: Habilidades de percepção; Núcleo B: Habilidades instrumentais; Núcleo C: habilidades de pensamento; Núcleo D: Habilidades de construção conceitual; Núcleo E: habilidades de construção metodológica; Núcleo F: Habilidades de construção social do conhecimento; Núcleo G: Habilidades metacognitivas.

Dentro do Núcleo A- Habilidades de Percepção estão incluídas as habilidades: Sensibilidade aos fenômenos, intuição, amplitude de percepção e percepção seletiva. Segundo a autora o desenvolvimento de tais habilidades muitas vezes é negligenciado por serem consideradas inerentes ao ser humano, contrária a essa ideia a autora 
argumenta que as habilidades de percepção são a porta de entrada para o conhecimento uma vez que, perceber significa receber e extrair informações do meio.

A habilidade Amplitude de Percepção, presente no núcleo A, permite que os indivíduos observem os objetos e fenômenos focando sua atenção a certas características e propriedades, tratando de obter informações importantes a partir dos próprios objetos e fenômenos observados. O desenvolvimento desta habilidade se justifica, pois segundo a autora nem todos os indivíduos percebem as mesmas coisas da mesma maneira, embora se encontrem diante do mesmo fenômeno. As aprendizagens que cada ser humano possui os levam a construir padrões de percepção pelos quais realizam novas percepções.

$\mathrm{Na}$ atividade experimental investigativa analisada neste trabalho, verificamos na etapa de manipulação e montagem do experimento momentos em que os alunos realizam um contato sensorial com os materiais. Tal contato associado à mediação dos professores possibilitou aos estudantes desenvolverem habilidades que consideramos levar a ampliação da percepção, ou seja, momentos em que esse contato sensorial permitiu aos estudantes observarem e extraírem informações a partir deste contato; vale ressaltar que tais informações foram fundamentais na resolução do problema proposto posteriormente.

Dessa forma em todos os turnos de fala em que reconhecemos o desenvolvimento da habilidade que amplia a percepção dos alunos, decidimos considerá-la como um indicador de Alfabetização Científica; por entendermos que ele complementa os indicadores proposto por Sasseron e Carvalho (2008), contribuindo dessa forma para a efetivação do processo de Alfabetização Científica. A denominação para este indicador é "Constatação".

\begin{tabular}{|l|l|}
\hline Constatação & $\begin{array}{l}\text { Indicador que antecipa os trabalhos } \\
\text { com os dados. Momentos em que o } \\
\text { contato sensorial com o objeto permite } \\
\text { ao aluno extrair informações e ampliar } \\
\text { suas percepções. }\end{array}$ \\
\hline
\end{tabular}

Quadro 4: Definição do Indicador Constatação 


\section{CAPÍTULO 3- RESULTADOS}

Neste momento apresentaremos nossos dados. Apresentaremos a transcrição dos episódios selecionados para cada etapa da aula na forma de quadros compostos por quatro colunas. A primeira coluna informa o turno de fala, já a segunda identifica o participante, a terceira coluna traz a transcrição integral da fala deste participante e a última coluna mostra as classificações dos turnos de fala que fizemos baseados no referencial teórico.

\section{1 - ETAPA 1: LEVANTAMENTO DE CONHECIMENTOS PRÉVIOS}

\begin{tabular}{|l|l|l|l|}
\hline Turno & Participante & \multicolumn{1}{|c|}{ Fala do Participante } & Indicadores \\
\hline 5 & Pr I & $\begin{array}{l}\text { Hoje a aula é sobre fotossíntese. } \\
\text { Vocês sabem o que é } \\
\text { fotossíntese? } \\
\text { É... é quando a planta usa os } \\
\text { raios do sol pra se alimentar. }\end{array}$ & \\
\hline 6 & Al 1 & Ela produz seu próprio alimento & \\
\hline 7 & Al 3 & $\begin{array}{l}\text { Alguém mais quer falar alguma } \\
\text { coisa sobre fotossíntese? O que } \\
\text { que vocês lembram? Vocês já } \\
\text { viram em alguma aula isso } \\
\text { daqui? }\end{array}$ & \\
\hline 8 & Al s & Sim:: & \\
\hline 9 & Al 4 & Na aula de microscópio & \\
\hline 10 & Al s & (risos) & $\begin{array}{l}\text { Fotossíntese é o processo em } \\
\text { que a planta produz seu próprio } \\
\text { alimento. }\end{array}$ \\
\hline 11 & Al 5 & $\begin{array}{l}\text { A planta faz; animal faz } \\
\text { fotossíntese? }\end{array}$ & \\
\hline 12 & Al s & Não :: & \\
\hline 14 & & & \\
\hline
\end{tabular}

Continua 


\begin{tabular}{|c|c|c|c|}
\hline Turno & Participante & Fala do Participante & Indicadores \\
\hline 15 & $\operatorname{Pr} I$ & $\begin{array}{l}\text { Então ó . A planta faz } \\
\text { (Professor coloca na lousa } \\
\text { palavras-chaves que os Al s } \\
\text { falaram sobre fotossíntese) } \\
\text { Planta, que mais vocês falaram? }\end{array}$ & \\
\hline 16 & Pr II & $\begin{array}{l}\text { Ela falou alimento. Mas o que } \\
\text { mais tem na fotossíntese? }\end{array}$ & \\
\hline 17 & $\mathrm{Al} 6$ & $\begin{array}{l}\text { Que a partir da clorofila que tem } \\
\text { nas folhas ela absorve a luz do } \\
\text { sol. } \\
\text { (Professor continua colocando } \\
\text { na lousa palavras que possuem } \\
\text { relação com a fotossíntese) }\end{array}$ & \\
\hline 18 & Pr I & Que mais? & \\
\hline 19 & Al 5 & Oxigênio & \\
\hline 20 & Pr I & Oxigênio. Que mais? & \\
\hline 21 & Al 1 & Gás Carbônico, água. & \\
\hline 22 & Pr I & Isso. & \\
\hline 23 & $\mathrm{Al} 4$ & Terra. & \\
\hline 24 & Pr II & Terra? Será que tem terra? & \\
\hline 25 & Alguns Al s & Sim:: & \\
\hline 26 & $\mathrm{Al} 6$ & Glicose & \\
\hline 27 & Pr I & Glicose. Ó perfeito & \\
\hline 28 & Pr III & E o que é glicose? & \\
\hline 29 & Al 7 & Açucar! & \\
\hline 30 & Al 6 & É a comida da planta & \\
\hline
\end{tabular}

Quadro 5 - Os turnos que caracteriza a etapa de levantamento dos conhecimentos prévios 
Este episódio ocorreu no início da aula. Os professores promoveram um diálogo com os alunos com o intuito de identificar os entendimentos que os alunos já possuíam sobre o tema que seria abordado na aula.

Nestes turnos iniciais os professores realizaram várias perguntas aos alunos sobre o tema fotossíntese. Os professores estimularam os alunos a explicitarem o que sabiam sobre o processo de fotossíntese. Ao analisarmos este episódio não podemos apontar indicadores de Alfabetização Científica uma vez que se tratando dos momentos iniciais, a atividade experimental ainda não proporcionou o desenvolvimento destes indicadores.

\section{2 - ETAPA 2: MANIPULAÇ̃̃O DO MATERIAL E MONTAGEM DO}

\section{EXPERIMENTO}

Esta etapa, conforme já apontado anteriormente contém cinco episódios, que foram divididos em duas fases: Fase A- Entrando em contato com os materiais e Fase B- Resolvendo problemas utilizando conhecimentos sobre os materiais.

\section{Etapa 2: Episódio 1}

\section{Fase A: Entrando em contato com os materiais}

O episódio 1 desta etapa, inicia-se no turno 32 e termina no turno 42.

\begin{tabular}{|l|l|l|c|}
\hline Turno & Participante & \multicolumn{1}{|c|}{ Fala do Participante } & $\begin{array}{c}\text { Indicadores de } \\
\text { A.C }\end{array}$ \\
\hline 32 & Pr I & $\begin{array}{l}\text { Pessoal e aí. Aconteceu alguma } \\
\text { coisa? }\end{array}$ & Constatação \\
\hline 33 & Al s & Mudou de cor, ficou amarelo. & \\
\hline 34 & Pr I & Mudou de cor! Que cor que ficou? & Constatação \\
\hline 35 & Al s & Amarelo & Constatação \\
\hline 36 & Pr I & $\begin{array}{l}\text { Cada grupo levanta para todo } \\
\text { Fundo ver! Ficou da mesma cor? }\end{array}$ & Ficou igual? \\
\hline 37 & Al s & Ficou. & Constatação \\
\hline 38 & Pr I & Então que cor que era? & Vermelho. \\
\hline 39 & Al s & Ficou amarelo? & \\
\hline 40 & Pr I & &
\end{tabular}




\begin{tabular}{|l|l|l|l|}
\hline Turno & Participante & \multicolumn{1}{|c|}{ Fala do Participante } & \multicolumn{1}{c|}{$\begin{array}{c}\text { Indicadores de } \\
\text { A.C }\end{array}$} \\
\hline 41 & Al s & Sim:: & $\begin{array}{l}\text { Então... Esse líquido vermelho } \\
\text { chama vermelho de cresol. } \\
\text { (professor escreve na lousa). O } \\
\text { que que é esse vermelho de } \\
\text { cresol? Ele é uma substância que } \\
\text { a gente chama de indicador } \\
\text { ácido -base tá? O que que o } \\
\text { indicador ácido-base faz? É uma } \\
\text { substância colorida que quando a } \\
\text { gente taca o ácido ou uma base } \\
\text { ela vai mudar de cor. Ééé... } \\
\text { Limão é ácido? }\end{array}$ \\
\hline
\end{tabular}

Quadro 6 - Os turnos e os indicadores de Alfabetização Científica identificados no episódio 1 da etapa de manipulação do material e montagem do experimento, fase A.

Neste episódio, cada grupo recebeu um tubo de ensaio contendo uma solução de vermelho de cresol, com o auxílio de um canudo, um representante de cada grupo assoprou no tubo. Os professores perguntaram aos alunos o que aconteceu. Os alunos perceberam que houve uma mudança de cor na solução e verbalizou qual era essa alteração. Os professores para se certificarem de que todos os alunos compreenderam a alteração ocorrida na substância, perguntaram qual cor o indicador possuía inicialmente e qual a cor que a solução adquiriu.

Observamos que os alunos estabeleceram um contato sensorial com o componente químico, o qual permitiu aos mesmos extraírem informações que ainda não possuíam a respeito daquela substância. Entendemos que estabelecer esse contato sensorial foi imprescindível na resolução do problema proposto pela atividade posteriormente. Nesse sentido classificamos essas ações como "Constatação".

\section{Etapa2: Episódio 2}

\section{Fase A: Entrando em Contato com os materiais}


Este episódio compreende os turnos 59 até o 63 e ocorre após os professores demonstrarem que utilizando vinagre, que é um ácido, o indicador adquire a mesma cor de quando os alunos sopraram e que, misturando à solução uma base, a soda cáustica, este indicador adquire outra cor.

\begin{tabular}{|l|l|l|c|}
\hline \multicolumn{1}{|c|}{ Turno } & Participante & \multicolumn{1}{|c|}{ Fala do Participante } & Indicadores de A.C \\
\hline 59 & Pr I & $\begin{array}{l}\text { Então olha só! Era vermelho, a } \\
\text { cor dele mesmo, aí quando você } \\
\text { taca um ácido que cor que fica? }\end{array}$ & \\
\hline 60 & Al s & Amarelo- alaranjado & Constatação \\
\hline 61 & Pr I & E quando você taca uma base? & \\
\hline 62 & Al s & Roxo. & Constatação \\
\hline 63 & Pr I & Vamos anotar isso? & \\
\hline
\end{tabular}

Quadro 7 - Os turnos e os indicadores de Alfabetização Científica identificados no episódio 2 da etapa de manipulação do material e montagem do experimento, fase A.

Novamente nesta etapa da atividade observamos a presença do indicador Constatação. O contato físico com essa substância permitiu aos alunos extraírem informações referentes à alteração da cor da substância.

\section{Etapa 2: Episódio 3}

\section{Fase A: Entrando em Contato com os materiais}

Este episódio inicia-se no turno 71 e termina no turno 83. Ele inicia com o questionamento de uma aluna relacionando a atividade de soprar com o canudo no vermelho de cresol e o fato do indicador mudar de cor. Tal pergunta desencadeou uma discussão entre os estudantes no sentido de compreender a alteração de cor obsevada.

\begin{tabular}{|l|l|l|l|}
\hline Turno & Participante & Fala do Participante & $\begin{array}{c}\text { Indicadores de } \\
\text { A.C }\end{array}$ \\
\hline 71 & Al 6 & $\begin{array}{l}\text { E porque quando a gente soprou } \\
\text { mudou de cor? }\end{array}$ & \\
\hline 72 & Pr III & Boa pergunta! & \\
\hline
\end{tabular}




\begin{tabular}{|c|c|c|c|}
\hline Turno & Participante & Fala do Participante & $\begin{array}{c}\text { Indicadores de } \\
\text { A.C }\end{array}$ \\
\hline 73 & Pr I & $\begin{array}{l}\text { Ó podem anotar no caderno ( a } \\
\text { anotação que o professor fez na } \\
\text { lousa) Vermelho de cresol } \\
\text { indicador ácido - base, quando } \\
\text { coloca ácido fica amarelo, } \\
\text { quando coloca base fica roxo. }\end{array}$ & \\
\hline 74 & Pr III & $\begin{array}{l}\text { A pergunta dela é a seguinte: } \\
\text { Quando colocou o vinagre aqui } \\
\text { que é ácido ficou...? }\end{array}$ & \\
\hline 75 & Al s & Amarelo. & Constatação \\
\hline 76 & Pr III & $\begin{array}{l}\text { E porque quando ela soprou } \\
\text { ficou amarelo? Ela soprou um } \\
\text { bafo de vinagre (risos) }\end{array}$ & \\
\hline 77 & Al s & (risos), Não:: & \\
\hline 78 & Al 1 & Ela soprou gás carbônico. & $\begin{array}{l}\text { Organização de } \\
\text { informações }\end{array}$ \\
\hline 79 & Pr III & $\begin{array}{l}\text { Ela soprou gás carbônico. E o } \\
\text { que aconteceu quando ela soprou } \\
\text { gás carbônico? }\end{array}$ & \\
\hline 80 & Al 1 & Misturou. & \\
\hline 81 & Pr III & $\begin{array}{l}\text { Vamos lá, Quando ela soprou } \\
\text { soltou gás carbônico, o gás } \\
\text { carbônico junto com a água se } \\
\text { transforma num ácido, o ácido } \\
\text { carbônico. E o que acontece } \\
\text { quando o vermelho de cresol } \\
\text { tem contato com ácido? }\end{array}$ & \\
\hline 82 & $\mathrm{Al} \mathrm{s}$ & Fica laranja. & Constatação \\
\hline
\end{tabular}




\begin{tabular}{|l|l|l|l|}
\hline Turno & Participante & \multicolumn{1}{|c|}{ Fala do Participante } & $\begin{array}{c}\text { Indicadores de } \\
\text { A.C }\end{array}$ \\
\hline 83 & Pr III & $\begin{array}{l}\text { Então olha o que aconteceu. } \\
\text { Quando o professor1 misturou } \\
\text { vinagre no vermelho de cresol } \\
\text { ele fez uma reação química, } \\
\text { quando vocês sopraram vocês } \\
\text { fizeram duas reações. Primeiro o } \\
\text { gás carbônico em contato com a } \\
\text { água se transformou num ácido, } \\
\text { depois esse ácido modificou, } \\
\text { ocorreu duas reações. }\end{array}$ & \\
\hline
\end{tabular}

Quadro 8 - Os turnos e os indicadores de Alfabetização Científica identificados no episódio 3 da etapa de manipulação do material e montagem do experimento, fase A.

Observamos neste episódio a presença novamente do Indicador de Alfabetização Científica: Constatação. Para os alunos compreenderem a mudança de cor do indicador quando eles assopraram, os professores retomaram a mudança de cor observada e os alunos mais uma vez verbalizam essa alteração. Os professores explicaram o porquê de o indicador mudar de cor quando em contato com diferentes substâncias.

\section{Etapa 2: Episódio 4}

\section{Fase A: Entrando em Contato com os materiais}

O episódio a seguir compreende os turnos: 96,97,98,99,100,101,102. Nestes turnos os professores buscaram verificar se os alunos realmente compreenderam como age um indicador ácido-base. Nesse sentido, fizeram várias perguntas para se certificarem do entendimento por parte dos alunos e realizaram uma sistematização utilizando a lousa.

\begin{tabular}{|l|l|l|c|}
\hline \multicolumn{1}{|c|}{ Turno } & Participante & \multicolumn{1}{|c|}{ Fala do Participante } & Indicadores de A.C \\
\hline 96 & Pr I & $\begin{array}{l}\text { Entenderam que o indicador } \\
\text { ácido-base, a gente taca ácido. }\end{array}$ & \\
\hline 97 & Al 10 & Fica amarelo. & Constatação \\
\hline
\end{tabular}




\begin{tabular}{|c|c|c|}
\hline 98 & Pr I & $\begin{array}{l}\text { Isso! Assim, esse daqui, tem } \\
\text { vários indicadores que tem } \\
\text { várias cores, tá, aí quando a } \\
\text { gente taca a base fica roxo, tá. E } \\
\text { porque quando a gente soprou } \\
\text { ficou amarelo/laranja? O que } \\
\text { que é...? }\end{array}$ \\
\hline 99 & $\mathrm{Al} \mathrm{s}$ & Ácido. \\
\hline 100 & $\operatorname{Pr} I$ & $\begin{array}{l}\text { O que que a gente tava soprando } \\
\text { lá? } \\
\text { O gás carbônico, quando eu } \\
\text { escrevo } \\
\mathrm{CO}_{2} \text { vocês entendem? } \\
\text { ( professor escreve na lousa) }\end{array}$ \\
\hline 101 & $\mathrm{Al} \mathrm{s}$ & Sim:: \\
\hline 102 & Pr I & $\begin{array}{l}\text { Gás carbônico quando ele entra } \\
\text { em contato com a água ele forma } \\
\text { o ácido, que a gente chama de } \\
\text { ácido carbônico, tá. Vocês } \\
\text { podem anotar isso daí também. }\end{array}$ \\
\hline
\end{tabular}

Quadro 9 - Os turnos e os indicadores de Alfabetização Científica identificados no episódio 4 da etapa de manipulação do material e montagem do experimento, fase A.

Observamos a presença do Indicador de Alfabetização Científica: Constatação (Quadro 9). A partir dos questionamentos dos professores os alunos observaramm os tubos de ensaio e constataram as alterações de cor, ao responderem corretamente as questões dos professores, os alunos indicaram que compreenderam como atua um indicador ácido-base.

\section{Etapa 2: Episódio 5}

\section{Fase B: Resolvendo problemas utilizando os conhecimentos sobre os materiais}

O episódio a seguir é um episódio longo que vai do turno 114 ao 159. Neste episódio os professores procuraram verificar se os alunos conseguiriam transpor os conhecimentos adquiridos até o momento, em outra situação. Para isso, os professores 
elaboraram um problema para os alunos. Eles tinham que definir e explicar qual a cor que o gelo seco, composto de gás carbônico em estado sólido, iria adquirir ao entrar em contato com o vermelho de cresol.

\begin{tabular}{|c|c|c|c|}
\hline Turno & Participante & Fala do Participante & Indicadores de A.C \\
\hline 114 & $\operatorname{Pr} \mathrm{I}$ & Do que que é feito gelo seco: & \\
\hline 115 & Aluno? & Água & \\
\hline 116 & Aluno? & $\mathrm{Ar}$ & \\
\hline 117 & Al 1 & Nitrogênio & \\
\hline 118 & Pr I & É feito de um gás & \\
\hline 119 & Al s & Gás Carbônico? & \\
\hline 120 & Pr I & $\begin{array}{l}\text { Isso. Então essa pedrinha que } \\
\text { vocês estão vendo é gás } \\
\text { carbônico puro.tá? É um gás na } \\
\text { forma de gelo, sólido. }\end{array}$ & \\
\hline 121 & Pr III & $\begin{array}{l}\text { Vocês conhecem as } \\
\text { propriedades da matéria, né? } \\
\text { Sólido, líquido e gasoso,né? }\end{array}$ & \\
\hline 122 & $\mathrm{Al} \mathrm{s}$ & Sim:: & \\
\hline 123 & Pr III & $\begin{array}{l}\text { O gelo lá na geladeira de casa } \\
\text { ele está o que? }\end{array}$ & \\
\hline 124 & $\mathrm{Al} \mathrm{s}$ & Gelado/ Sólido & \\
\hline 125 & Pr III & $\begin{array}{l}\text { Gelado e sólido. Se tirar ele e } \\
\text { colocar pra fora da geladeira o } \\
\text { que que acontece? }\end{array}$ & \\
\hline 126 & $\mathrm{Al} \mathrm{s}$ & Derrete & \\
\hline 127 & Pr III & E como vai ficar? & \\
\hline 128 & $\mathrm{Al} \mathrm{s}$ & Líquido & \\
\hline 129 & Pr III & E se eu aquecer no fogo? & \\
\hline 130 & $\mathrm{Al} \mathrm{s}$ & Gasoso, ele evapora & \\
\hline 131 & Pr III & $\begin{array}{l}\text { Esse gelo seco ele não passa } \\
\text { para o estado líquido, ele vai } \\
\text { direto do sólido para o gasoso. }\end{array}$ & \\
\hline 132 & $\mathrm{Al} 4$ & Mas como faz? & \\
\hline
\end{tabular}




\begin{tabular}{|c|c|c|c|}
\hline Turno & Participante & Fala do Participante & Indicadores de A.C \\
\hline 133 & Pr I & $\begin{array}{l}\text { É uma máquina que faz o gelo } \\
\text { seco, não dá pra fazer em casa. } \\
\text { (professores passam o frasco } \\
\text { com gelo seco para os } \mathrm{Al} \mathrm{s} \text { ) }\end{array}$ & \\
\hline 134 & Pr I & $\begin{array}{l}\text { Isso daqui que o professor3 } \\
\text { falou, ele falou assim passa do } \\
\text { estado sólido... Calma todo } \\
\text { mundo vai botar a mão presta } \\
\text { atenção aqui). O que o } \\
\text { professor3 falou foi assim ele } \\
\text { não derrete e vira água, tá. Ele } \\
\text { vai passar do estado sólido pro } \\
\text { liquido, eu vou deixar essa } \\
\text { pedrinha aqui de gelo, aqui vcs } \\
\text { vão ver que ele vai sumir e não } \\
\text { vão formar água nenhuma. }\end{array}$ & \\
\hline 135 & Al 1 & $\begin{array}{l}\text { Professor uma pergunta. E se } \\
\text { agente jogar uma pedra nesse } \\
\text { negócio aí. (aponta para o } \\
\text { vermelho de cresol) }\end{array}$ & Aquisição de dados \\
\hline 136 & Pr I & $\begin{array}{l}\text { Boa! O que você acha que vai } \\
\text { acontecer? }\end{array}$ & \\
\hline \multirow[t]{2}{*}{137} & \multirow[t]{2}{*}{ Al 1} & \multirow[t]{2}{*}{ Vai evaporar, vai mudar de cor. } & Previsão \\
\hline & & & $\begin{array}{l}\text { Levantamento de } \\
\text { hipóteses }\end{array}$ \\
\hline 138 & Pr III & $\begin{array}{l}\text { Vai evaporar, vai mudar de cor, } \\
\text { que mais? }\end{array}$ & \\
\hline \multirow[t]{2}{*}{139} & \multirow[t]{2}{*}{ Al 9} & \multirow[t]{2}{*}{ Vai sair bolhas } & Previsão \\
\hline & & & $\begin{array}{l}\text { Levantamento de } \\
\text { hipóteses }\end{array}$ \\
\hline 140 & Pr III & $\begin{array}{l}\text { Qual cor vocês acham que vai } \\
\text { ficar? }\end{array}$ & \\
\hline \multirow[t]{2}{*}{141} & \multirow[t]{2}{*}{$\mathrm{Al} 4$} & \multirow[t]{2}{*}{ Vai ficar roxo } & Previsão \\
\hline & & & $\begin{array}{l}\text { Levantamento de } \\
\text { hipóteses }\end{array}$ \\
\hline \multirow[t]{2}{*}{142} & \multirow[t]{2}{*}{ Al 1} & \multirow[t]{2}{*}{ Vai ficar amarelo } & Previsão \\
\hline & & & $\begin{array}{l}\text { Levantamento de } \\
\text { hipóteses }\end{array}$ \\
\hline
\end{tabular}

Continua 


\begin{tabular}{|c|c|c|c|}
\hline Turno & Participante & Fala do Participante & Indicadores de A.C \\
\hline 143 & Pr III & $\begin{array}{l}\text { Um falou que vai ficar roxo o } \\
\text { outro falou que vai ficar } \\
\text { amarelo, alguém sabe explicar } \\
\text { porque da mudança de cor? }\end{array}$ & \\
\hline 144 & Al 3 & $\begin{array}{l}\text { Amarelo, Por causa do gás } \\
\text { carbônico }\end{array}$ & Explicação \\
\hline 145 & Pr I & $\begin{array}{l}\text { E o que aconteceu quando vocês } \\
\text { colocaram gás carbônico aqui ( } \\
\text { vermelho de cresol). }\end{array}$ & \\
\hline 146 & $\mathrm{Al} \mathrm{s}$ & Mudou de cor & $\begin{array}{l}\text { Organizando } \\
\text { informações }\end{array}$ \\
\hline 147 & Pr III & Que cor & \\
\hline 148 & $\mathrm{Al} \mathrm{s}$ & Laranja/ amarelo & $\begin{array}{l}\text { Organizando } \\
\text { informações }\end{array}$ \\
\hline 149 & Pr III & Que cor vai ficar ali & \\
\hline 150 & Al s & Laranja/amarelo & Previsão \\
\hline 151 & Pr III & Por quê? & \\
\hline 152 & Al s & Por causa do gás carbônico & Justificativa \\
\hline 153 & Pr III & $\begin{array}{l}\text { Ele vai ficar ácido em contato } \\
\text { com a água. }\end{array}$ & \\
\hline 154 & Pr I & $\begin{array}{l}\text { Vamos prestar atenção aqui. Nós } \\
\text { íamos colocar o gelo seco aqui } \\
\text { dentro(vermelho de cresol). }\end{array}$ & \\
\hline 155 & $\mathrm{Al} \mathrm{s}$ & $\begin{array}{l}\text { Nossa que legal. Mudando de } \\
\text { cor. }\end{array}$ & \\
\hline 156 & Pr I & Porque ficou amarelo? & \\
\hline 157 & Al 6 & $\begin{array}{l}\text { Por causa do gás carbônico, que } \\
\text { é um ácido }\end{array}$ & $\begin{array}{c}\text { Justificativa } \\
\text { Explicação }\end{array}$ \\
\hline 158 & Pr III & O gás carbônico não é um ácido & \\
\hline 159 & Al 6 & $\begin{array}{l}\text { Desculpa! Por causa do gás } \\
\text { carbônico que se junta com a } \\
\text { água e fica ácido }\end{array}$ & $\begin{array}{l}\text { Justificativa } \\
\text { Explicação }\end{array}$ \\
\hline
\end{tabular}

Quadro 10 - Os turnos e os indicadores de Alfabetização Científica identificados no episódio 5 da etapa de manipulação do material e montagem do experimento, fase B.

Inicialmente os professores realizaram uma etapa de levantamento de conhecimentos prévios. Os professores fizeram várias perguntas sobre os estados físicos da água e das mudanças verificadas na água. Os alunos responderam todas as perguntas sinalizando que conheciam bem este tema. Não classificamos estes turnos, pois a 
exemplo da etapa inicial, trata-se também de um momento de levantamento de conhecimentos prévios, onde alunos ainda não iniciaram o processo de investigação.

Em seguida os professores apresentaram aos alunos o gelo seco, e explicaram que esta substância estava no estado sólido, e que passa para o estado gasoso sem antes passar pelo líquido; isso porque essa pedra não é formada por água, mas sim por gás carbônico no estado sólido.

No turno 135 um aluno se antecipou aos professores e propôs que a pedra de gelo seco fosse colocada em contato com a solução de vermelho de cresol. Classificamos este turno como aquisição de informações, pois é o aluno que propõe uma metodologia para obter dados.

Os professores não responderam ao questionamento do aluno e estimularam a classe apresentar suas ideias.

Os alunos tinham um problema para resolver: $\mathrm{O}$ que acontece com gelo seco quando colocado numa solução de vermelho de cresol?

Nos turnos 137,139,141 e 142 verificamos a ocorrência dos indicadores levantamento de hipósteses e previsão. Estes turnos representam bem como o indicador Constatação favoreceu a ocorrência dos indicadores levantamento de hipóteses e de previsão. Uma vez realizado o processo de constatação, os alunos neste momento da aula conseguem realizar o levantamento de hipóteses e previsões.

Nos turnos 146 e 148 os alunos retomaram a atividade realizada anteriormente com o vermelho de cresol, e organizaram informações. Mais uma vez é perceptível a relação direta do indicador Constatação com a ocorrência de outros indicadores. Neste turno a relação se dá com o indicador organizando informações. Percebam que ao organizar as informações eles retomam os momentos de Constatação realizados anterirmente. Em seguida, os mesmos explicaram e justificaram os motivos da mudança da cor do indicador. 


\begin{tabular}{|c|c|c|}
\hline Etapa 2 & $\begin{array}{c}\text { Indicadores de } \\
\text { Alfabetização Científica }\end{array}$ & $\begin{array}{c}\text { Turnos de fala em que } \\
\text { determinado indicador } \\
\text { aparece }\end{array}$ \\
\hline $\begin{array}{c}\text { Entrando em Contato } \\
\text { com os materiais }\end{array}$ & Constatação & 9 \\
\hline \multirow{6}{*}{$\begin{array}{l}\text { Resolvendo problemas } \\
\text { utilizando } \\
\text { conhecimento sobre os } \\
\text { materiais }\end{array}$} & Organizando Informações & 3 \\
\hline & Aquisição de dados & 1 \\
\hline & Previsão & 5 \\
\hline & Levantamento de hipóteses & 4 \\
\hline & Justificativa & 3 \\
\hline & Explicação & 3 \\
\hline
\end{tabular}

Quadro 11 - Quantidade de turnos em que cada indicador aparece na etapa 2

\section{3 - ETAPA 3: INTERPRETACÃO E DISCUSSÃO DOS RESULTADOS DO}

\section{EXPERIMENTO}

Esta etapa é composta por dois episódios, ela acontece depois que os alunos montaram o experimento,

\section{Etapa 3: Episódio 1}

Neste episódio que compreende os turnos 162 até o 196, os professores retomaram a montagem do experimento realizado, e também indagaram os alunos sobre os possíveis resultados do experimento.

\begin{tabular}{|l|l|l|c|}
\hline Turno & Participante & \multicolumn{1}{|c|}{ Fala do Participante } & Indicadores de A.C \\
\hline 162 & Al 5 & $\begin{array}{l}\text { Primeiro tinha vermelho de } \\
\text { cresol nos potinhos, aí em um } \\
\text { deles a gente só tampou com } \\
\text { papel filme, no outro a gente } \\
\text { colocou uma folha e também } \\
\text { tampou com esse papel filme e } \\
\text { no terceiro a gente colocou a } \\
\text { folha e colocou papel alumínio }\end{array}$ & \\
& & Organizando \\
& & \\
\hline
\end{tabular}




\begin{tabular}{|l|l|l|l|}
\hline 163 & Pr I & $\begin{array}{l}\text { Tá, e o que a gente fez depois } \\
\text { disso daí, que a gente montou? } \\
\text { Oh, de onde que o Pr II tá } \\
\text { tirando esses tubinhos? }\end{array}$ & \\
\hline 164 & Al 6 & Dá luz & $\begin{array}{l}\text { Organizando } \\
\text { Informações }\end{array}$ \\
\hline 165 & Pr I & $\begin{array}{l}\text { Então, gente montou isso daí ,e } \\
\text { colocou na luz, né. Vocês } \\
\text { lembram o que é esse liquido } \\
\text { vermelho, que é o vermelho de } \\
\text { cresol faz? }\end{array}$ & \\
\hline 166 & Al s & Sim & \\
\hline 167 & Pr I & E o que que ele faz & \\
\hline
\end{tabular}

\begin{tabular}{|c|c|c|c|}
\hline 168 & Al 6 & Ele é um indicador ácido-base & $\begin{array}{l}\text { Organizando } \\
\text { Informações }\end{array}$ \\
\hline 169 & Pr I & $\begin{array}{l}\text { Isso, indica ácido-base. Ele pode } \\
\text { mudar de cor. Ó o que vocês } \\
\text { acham? Vocês tão vendo se } \\
\text { aconteceu alguma coisa aí? } \\
\text { ( aponta para os tubos que estão } \\
\text { na mesa dos Al s) }\end{array}$ & \\
\hline 170 & Al s & Não & \\
\hline 171 & Pr I & $\begin{array}{l}\text { Antes de abrir! O que vocês } \\
\text { acham que aconteceu com o que } \\
\text { estava fechado? }\end{array}$ & \\
\hline 172 & Al 7 & Mudou de cor! & Previsão \\
\hline 173 & Pr I & Mudou de cor & \\
\hline 174 & Pr I & $\begin{array}{l}\text { Quem que acha que mudou de } \\
\text { cor levanta a mão } \\
\text { ( A maioria dos Al s levantam as } \\
\text { mãos) }\end{array}$ & \\
\hline
\end{tabular}




\begin{tabular}{|c|c|c|c|}
\hline 175 & Pr I & $\begin{array}{l}\text { Quem acha que não mudou de } \\
\text { cor levanta a mão. } \\
\text { ( poucos Al s levantam as mão) }\end{array}$ & \\
\hline 176 & Pr I & $\begin{array}{l}\text { Quem acha que não mudou de } \\
\text { cor, por que não mudou de cor? }\end{array}$ & \\
\hline 177 & $\mathrm{Al} 7$ & Porque não entrou luz. & $\begin{array}{c}\text { Levantamento de } \\
\text { hipóteses }\end{array}$ \\
\hline 178 & Pr I & $\begin{array}{l}\text { Porque não entrou luz. Que } \\
\text { mais? } \\
\text { Ó, eu to perguntando desde } \\
\text { daqui especificamente } \\
\text { (PROFESSOR MOSTRA } \\
\text { OBJETO PARA OS AL S), } \\
\text { esquecem os outros,. Tem gente } \\
\text { que acha mudou de cor, tem } \\
\text { gente que acha que não mudou } \\
\text { de cor. Aí ó, você achou que não } \\
\text { mudou de cor porque não entrou } \\
\text { luz. Alguém tem mais alguma } \\
\text { hipótese? }\end{array}$ & \\
\hline 179 & $\mathrm{Al} 4$ & $\begin{array}{l}\text { Eu tenho professor, daqueles } \\
\text { negocinhos que vocês tavam } \\
\text { escrevendo na lousa, ia ficar } \\
\text { laranja por causa do... do ácido }\end{array}$ & $\begin{array}{l}\text { Levantamento de } \\
\text { hipóteses }\end{array}$ \\
\hline 180 & Pr I & Mas tem ácido aqui dentro? & \\
\hline 181 & $\mathrm{Al} 4$ & Depende da planta & \\
\hline 182 & Pr I & $\begin{array}{l}\text { É a mesma planta que aquela lá } \\
\text { (professor aponta para o tubo } \\
\text { que está descoberto) Tem ácido } \\
\text { aqui dentro? }\end{array}$ & \\
\hline 183 & Pr II & $\begin{array}{l}\text { Se tivesse ácido nessa planta, teria } \\
\text { naquela né? É a mesma. }\end{array}$ & \\
\hline
\end{tabular}




\begin{tabular}{|c|c|c|c|}
\hline 184 & Pr I & $\begin{array}{l}\text { Então ó! Tem duas opções mudou } \\
\text { de cor e não mudou de cor, aqui } \\
\text { não mudou de cor ficou vermelho, } \\
\text { agora tem um monte de gente que } \\
\text { falou que mudou de cor. Porque } \\
\text { mudou de cor? }\end{array}$ & \\
\hline 185 & Al 11 & Por causa da planta & $\begin{array}{l}\text { Levantamento de } \\
\text { hipóteses }\end{array}$ \\
\hline 186 & Al 5 & Porque a planta não tinha luz & $\begin{array}{l}\text { Levantamento de } \\
\text { hipóteses }\end{array}$ \\
\hline 187 & Aluno? & Falta de oxigênio & $\begin{array}{c}\text { Levantamento de } \\
\text { hipóteses }\end{array}$ \\
\hline 188 & Pr I & Falta de oxigênio. & \\
\hline 189 & $\mathrm{Al} 11$ & $\begin{array}{l}\text { Gás Carbônico. A planta liberou } \\
\text { gás carbônico, aí ela fechada não } \\
\text { entrou luz, aí eu acho que mudou } \\
\text { de cor. }\end{array}$ & $\begin{array}{l}\text { Levantamento de } \\
\text { hipóteses }\end{array}$ \\
\hline 190 & $\mathrm{Al} 6$ & $\begin{array}{l}\text { E porque a planta libera gás } \\
\text { carbônico? É ao contrário ela } \\
\text { libera oxigênio e absorve o gás } \\
\text { carbônico. }\end{array}$ & \\
\hline 191 & Pr I & $\begin{array}{l}\text { Tava tudo dessa cor (mostrando o } \\
\text { tubo de ensaio controle). Vamos } \\
\text { abrir o papel agora, pra gente ver } \\
\text { O que aconteceu. }\end{array}$ & \\
\hline 192 & $\mathrm{Al} \mathrm{s}$ & Nossa! Ficou amarelo/ laranja & Constatação \\
\hline 193 & $\mathrm{Al} 3$ & $\begin{array}{l}\text { Eu acho que mudou de cor porque } \\
\text { ela aqueceu a planta e ela soltou } \\
\text { algum tipo de liquido acido aí } \\
\text { mudou a cor }\end{array}$ & Explicação \\
\hline 194 & Pr I & $\begin{array}{l}\text { É uma hipótese. Alguém tem } \\
\text { mais alguma hipótese? } \\
\text { Ó vocês só vão. Ó, pensa assim, } \\
\text { ou mudou de cor ou não mudou } \\
\text { de cor. Mudou de cor. Vocês } \\
\text { tem alguma hipótese porque } \\
\text { mudou de cor? }\end{array}$ & \\
\hline 195 & Al 11 & Por causa do gás carbônico & Justificativa \\
\hline 196 & Al 1 & A planta criou ácido & $\begin{array}{l}\text { Levantamento de } \\
\text { hipóteses }\end{array}$ \\
\hline 197 & Pr I & Porque a planta criou ácido, por & \\
\hline
\end{tabular}




\begin{tabular}{|c|c|c|c|}
\hline & & causa do gás carbônico. & \\
\hline 198 & Al 12 & $\begin{array}{l}\text { Professor, é porque aqui tá } \\
\text { mostrando que a planta ela } \\
\text { murchou e ela na solta oxigênio? } \\
\text { E aqui dentro ta fechado. Por } \\
\text { isso que ela murchou. }\end{array}$ & $\begin{array}{l}\text { Levantamento de } \\
\text { hipóteses }\end{array}$ \\
\hline 199 & Pr I & Tá vamos lá & \\
\hline 200 & Pr I & $\begin{array}{l}\text { A planta, é só uma parte da } \\
\text { planta essa folhas. Posso fazer } \\
\text { isso sem destacar da arvore, } \\
\text { deixar ela fora da arvore, ela não } \\
\text { vai murchar também? Porque ela } \\
\text { desidrata, ela perde água }\end{array}$ & \\
\hline 201 & Pr I & $\begin{array}{l}\text { É que depende. Depende de } \\
\text { como a gente amarrou aí, } \\
\text { depende se ficou mais tempo ou } \\
\text { não da luz, porque tem uma } \\
\text { lâmpada amarela, ela é } \\
\text { incandescente, ela é quente, tá? } \\
\text { Então se você botar perto do } \\
\text { negócio quente, vai poder } \\
\text { desidratar mais ou menos. } \\
\text { Mas vocês acham que foi o calor } \\
\text { que fez isso? Que mudou de cor? }\end{array}$ & \\
\hline 202 & Al s & Não & \\
\hline 203 & Pr I & $\begin{array}{l}\text { Assim, porque a gente pode falar } \\
\text { que não foi o calor? }\end{array}$ & \\
\hline 204 & Al 13 & Porque ele tava fechado & Justificativa \\
\hline 205 & Pr I & $\begin{array}{l}\text { Ó, olha só comparando com os } \\
\text { outros tubinhos, a gente } \\
\text { consegue justificar que não foi o } \\
\text { calor? }\end{array}$ & \\
\hline 206 & Pr II & $\begin{array}{l}\text { Todas receberam luz? Então se } \\
\text { fosse o calor }\end{array}$ & \\
\hline 207 & Al 6 & Todas iam mudar & $\begin{array}{c}\text { Previsão } \\
\text { Raciocínio Lógico }\end{array}$ \\
\hline 208 & Pr I & Todas mudariam & \\
\hline
\end{tabular}




\begin{tabular}{|c|c|c|c|}
\hline Turno & Participante & Fala do Participante & Indicadores de A.C \\
\hline 209 & Al 14 & $\begin{array}{l}\text { Professor, olha o que a gente } \\
\text { acabou de ver, que esta ficou } \\
\text { muito mais clara, essa ficou um } \\
\text { pouco menos clara e essa ficou } \\
\text { mais vermelha }\end{array}$ & Constatação \\
\hline 210 & Pr I & $\begin{array}{l}\text { Legal, ó... das duas que tem } \\
\text { plantinhas, uma ficou bem clara, } \\
\text { amarela, laranja e a outra ficou } \\
\text { mais ou menos vermelho claro. }\end{array}$ & \\
\hline \multirow[t]{3}{*}{211} & \multirow[t]{3}{*}{ Al 9} & \multirow{3}{*}{$\begin{array}{l}\text { Eu acho que essa daqui que } \\
\text { ficou amarela por causa da luz, } \\
\text { porque era a única que tava } \\
\text { tampada. E a outra se tava } \\
\text { tampada também ia ficar desse } \\
\text { jeito. }\end{array}$} & $\begin{array}{l}\text { Levantamento de } \\
\text { hipóteses }\end{array}$ \\
\hline & & & Previsão \\
\hline & & & Raciocínio lógico \\
\hline 212 & $\operatorname{Pr} I$ & $\begin{array}{l}\text { Tá bom, vamos lá. Vamo } \\
\text { pensar, ó. (professor pega tubos } \\
\text { de ensaio e mostra para Al s). } \\
\text { Este daqui não tinha planta, } \\
\text { ficou do jeito que estava, este } \\
\text { daqui tinha planta e tomou luz, } \\
\text { ficou um poquinho laranjado, } \\
\text { mas ficou vermelhinho e essa } \\
\text { daqui tinha planta e não tomou } \\
\text { luz, ficou meio amarelo, ta? Que } \\
\text { que vc falou? } \\
\text { (professor aponta para aluno) }\end{array}$ & \\
\hline
\end{tabular}




\begin{tabular}{|c|c|c|c|}
\hline Turno & Participante & Fala do Participante & Indicadores de A.C \\
\hline 213 & $\mathrm{Al} 9$ & $\begin{array}{l}\text { Eu achei que a que não tomou } \\
\text { luz, que a que essa fez diferença, } \\
\text { da luz. Porque as outras tomou } \\
\text { luz }\end{array}$ & Justificativa \\
\hline 214 & Pr I & $\begin{array}{l}\text { Então quer dizer que o fato de } \\
\text { não tomar luz que deixa } \\
\text { amarela? }\end{array}$ & \\
\hline 215 & Al 6 & $\begin{array}{l}\text { Será que a falta de luz fez com } \\
\text { que a plantinha murchasse e que } \\
\text { ela soltasse algum tipo de acido? }\end{array}$ & $\begin{array}{l}\text { Levantamento de } \\
\text { hipóteses }\end{array}$ \\
\hline & & & Explicação \\
\hline 216 & Pr I & $\begin{array}{l}\text { A falta de luz fez a plantinha } \\
\text { murchar e liberar algum ácido? } \\
\text { Mas ó.. eu tinha falado sobre } \\
\text { desidratação, a planta murcha } \\
\text { quando ta desidradata. O que } \\
\text { podia ter desidratado ali elas? }\end{array}$ & \\
\hline 217 & $\mathrm{Al} \mathrm{s}$ & Calor & $\begin{array}{c}\text { Levantamento de } \\
\text { hipóteses }\end{array}$ \\
\hline 218 & Pr I & $\begin{array}{l}\text { Calor ajuda desidratar? Este } \\
\text { daqui tava submetido ao calor } \\
\text { também (professor mostra um } \\
\text { dos tubos de ensaio) }\end{array}$ & \\
\hline 219 & Al 1 & $\begin{array}{l}\text { Será que é por causa da } \\
\text { imunidade aí a planta ficou la } \\
\text { que soltou algum gás e fez esse } \\
\text { efeito? }\end{array}$ & $\begin{array}{l}\text { Levantamento de } \\
\text { hipóteses }\end{array}$ \\
\hline 220 & Pr II & E e qual gás é esse & \\
\hline 221 & Al 1 & O oxigênio & $\begin{array}{c}\text { Levantamento de } \\
\text { hipóteses }\end{array}$ \\
\hline
\end{tabular}




\begin{tabular}{|c|c|c|c|}
\hline Turno & Participante & Fala do Participante & Indicadores de A.C \\
\hline 222 & Pr II & $\begin{array}{l}\text { O oxigênio. Pra ela soltar, você } \\
\text { fala tampada né? Pra ela soltar o } \\
\text { oxigênio, o que ela tem que ta } \\
\text { fazendo? } \\
\text { Heim? O que vocês acham? A } \\
\text { planta liberou um gás, vamos } \\
\text { continuar aqui, a planta liberou } \\
\text { um gás, a tampada, e que é } \\
\text { oxigênio que ela liberou né? Foi } \\
\text { isso que ele falou, e ela pra } \\
\text { liberar o oxigênio ela tem que ta } \\
\text { fazendo o que? }\end{array}$ & \\
\hline 223 & $\mathrm{Al} 6$ & Ela tem que ganhar luz & $\begin{array}{l}\text { Organizando } \\
\text { informações }\end{array}$ \\
\hline 224 & Al 1 & $\begin{array}{l}\text { Ela precisa de coiso de... gás } \\
\text { carbônico }\end{array}$ & $\begin{array}{l}\text { Organizando } \\
\text { Informações }\end{array}$ \\
\hline 225 & Pr II & $\begin{array}{l}\text { Então tá... então agora continua. } \\
\text { Tem o oxigênio. Tem outros } \\
\text { gases? }\end{array}$ & \\
\hline 226 & Pr II & $\begin{array}{l}\text { Vocês acham que a planta } \\
\text { tampada liberou gás carbônico } \\
\text { ou oxigênio? }\end{array}$ & \\
\hline 227 & $\mathrm{Al} \mathrm{s}$ & Oxigênio & \\
\hline 228 & Pr II & E como ela libera o oxigênio? & \\
\hline 229 & $\mathrm{Al} 5$ & Fazendo a fotossíntese & $\begin{array}{l}\text { Organizando } \\
\text { Informações }\end{array}$ \\
\hline 230 & Pr II & E como ela faz fotossíntese? & \\
\hline 231 & $\mathrm{Al} 5$ & Quando tem luz & $\begin{array}{l}\text { Organizando } \\
\text { informações }\end{array}$ \\
\hline 232 & Pr II & $\begin{array}{l}\text { E quando não tem luz. Ela faz } \\
\text { fotossíntese? }\end{array}$ & \\
\hline 233 & $\mathrm{Al} \mathrm{s}$ & Não & \\
\hline 234 & Pr II & $\begin{array}{l}\text { Então ta, a que estava sem } \\
\text { tampar nós podemos dizer que } \\
\text { ela estava fazendo fotossíntese? }\end{array}$ & \\
\hline
\end{tabular}

Quadro 12 - Os turnos e os indicadores de Alfabetização Científica identificados no episódio 1 da etapa de interpretação e discussão dos resultados do experimento. 
Neste episódio (Quadro 12) verificamos a presença de vários indicadores de Alfabetização Científica. Logo no início do episódio, os alunos retomaram as atividades realizadas anteriormente. Neste momento verificamos a presença do indicador “Organizando Informações”. Em seguida, o professor questionou o que poderia ter ocorrido com os tubos de ensaio. Os alunos levantaram hipóteses e tentaram explicá-las. Contudo, vale ressaltar que as hipóteses levantadas tentavam relacionar o experimento com a etapa anterior, ou seja, o trabalho com o indicador ácido-base.

No turno 191 quando é retirado o papel alumínio do tubo de ensaio e eles realmente verificaram que havia mudado de cor e adquirido a colaração amarelada, eles continuaram levantando hipóteses para explicar essa alteração. As hipóteses levantadas apontaram para a presença do gás carbônico, no tubo de ensaio. Nesse sentido, os alunos procuraram dar explicações e justificativas na tentativa de justificar a presença do gás carbônico no tubo. No entanto, as hipóteses e explicações levantadas não faziam a relação correta entre a mudança de cor e a presença do gás carbônico no tubo. Dessa forma, os professores continuaram discutindo com o intuito de rebater as hipóteses e explicações dadas até o momento.

\section{Etapa 3: Episódio 2}

Este episódio é bem extenso e começa no Turno 246 e termina no Turno 386. Muitos destes turnos não apresentaram Indicadores de Alfabetização Científica, porém consideramos que influenciaram diretamente na ocorrência de indicadores em outros turnos, em função disso, optamos por mantê-los no episódio.

\begin{tabular}{|l|l|l|l|}
\hline Turno & Participante & \multicolumn{1}{|c|}{ Fala do Participante } & Indicadores de A.C \\
\hline 246 & Pr I & $\begin{array}{l}\text { A planta respira? Quando ela } \\
\text { respira? De dia, de noite, toda } \\
\text { hora? }\end{array}$ & \\
& $\begin{array}{l}\text { Ó pensam na gente. A gente } \\
\text { respira, quando? }\end{array}$ & \\
\hline 247 & Al s & Toda hora & \\
\hline 248 & Pr I & Até dormindo? & \\
\hline 249 & Al s & Sim & \\
\hline
\end{tabular}




\begin{tabular}{|c|c|c|c|}
\hline 250 & Pr I & E a planta? & \\
\hline 251 & $\mathrm{Al} \mathrm{s}$ & Também & \\
\hline 252 & Pr I & $\begin{array}{l}\text { Oh, a gente ta adicionando uma } \\
\text { informação nova pra vocês } \\
\text { criarem novas hipóteses. } \\
\text { Vamos pensar só em gases. A } \\
\text { fotossíntese, quais são os gases } \\
\text { pra fazer a fotossíntese? Quais } \\
\text { gases precisam? }\end{array}$ & \\
\hline 253 & $\mathrm{Al} \mathrm{s}$ & Gás carbônico & $\begin{array}{l}\text { Seriação de } \\
\text { informações }\end{array}$ \\
\hline 254 & Pr I & E assim, que gás é produzido? & \\
\hline 255 & $\mathrm{Al} 9$ & Oxigênio & $\begin{array}{l}\text { Seriação de } \\
\text { informações }\end{array}$ \\
\hline 256 & Pr I & $\begin{array}{l}\text { Pra fotossíntese precisa de gás } \\
\text { carbônico pra produzir o } \\
\text { oxigênio, não é? Pra respiração } \\
\text { você precisa do oxigênio e } \\
\text { produz o gás carbônico. } \\
\text { E aí? Com essas novas } \\
\text { informações vocês conseguem } \\
\text { bolar novas hipóteses? }\end{array}$ & \\
\hline 257 & Pr I & Pode falar, são hipóteses. & \\
\hline 258 & $\mathrm{Al} 6$ & $\begin{array}{l}\text { Eu tenho uma dúvida. No caso } \\
\text { da planta, ela respira a todo } \\
\text { momento, certo? Mas ela, por } \\
\text { exemplo, aconteceu alguma } \\
\text { coisa que aí inverteu aí ela } \\
\text { absorve o oxigênio e libera o gás } \\
\text { carbônico que juntou com a água } \\
\text { e virou acido carbônico? }\end{array}$ & $\begin{array}{l}\text { Levantamento de } \\
\text { hipóteses }\end{array}$ \\
\hline
\end{tabular}




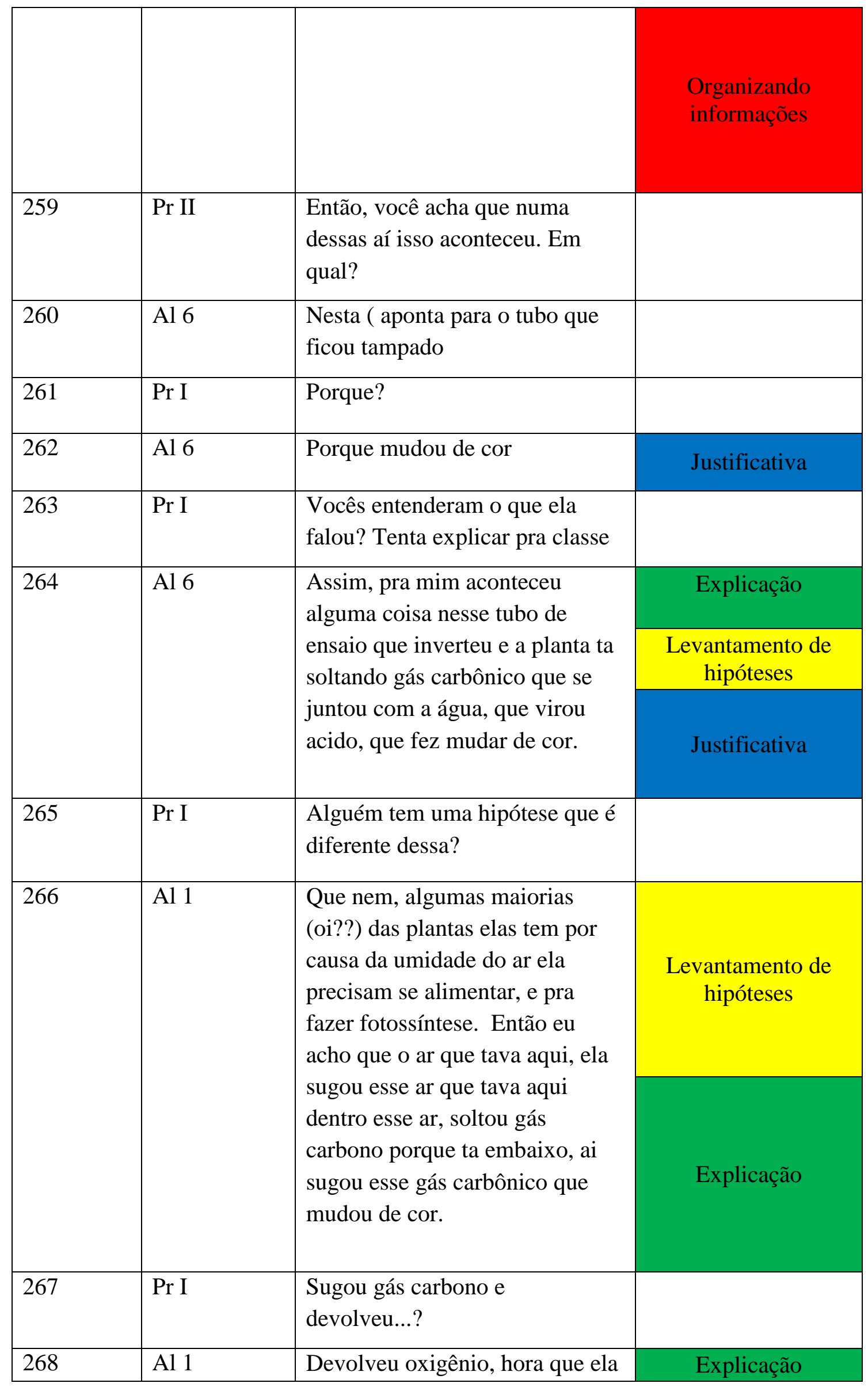




\begin{tabular}{|c|c|c|c|}
\hline & & $\begin{array}{l}\text { sugou o gás } \\
\text { carbono...(inaudível) }\end{array}$ & \\
\hline 269 & Pr I & $\begin{array}{l}\text { Tá, você ta falando que em } \\
\text { algum desses vidrinhos } \\
\text { aconteceu isso. Qual vidrinho } \\
\text { você ta falando? }\end{array}$ & \\
\hline 270 & Al 1 & Tampado & \\
\hline 271 & Pr I & $\begin{array}{l}\text { Alguém tem mais alguma } \\
\text { hipótese? }\end{array}$ & \\
\hline 272 & Pr II & $\begin{array}{l}\text { Em cima do que ela falou ali, } \\
\text { alguém concorda? Discorda? }\end{array}$ & \\
\hline 273 & Pr III & $\begin{array}{l}\text { Pessoal, vamos tentar fazer uma } \\
\text { associação. } \\
\text { O que fizeram, lembram do } \\
\text { experimento que a gente fez com } \\
\text { o canudinho? }\end{array}$ & \\
\hline 274 & $\mathrm{Al} \mathrm{s}$ & Sim & \\
\hline 275 & Pr III & $\begin{array}{l}\text { Aí a cor ficou parecida com } \\
\text { qual? }\end{array}$ & \\
\hline 276 & $\mathrm{Al} \mathrm{s}$ & Com o tampado & $\begin{array}{l}\text { Organizando } \\
\text { informações }\end{array}$ \\
\hline 277 & Pr III & O que tem de parecido? & \\
\hline 278 & $\mathrm{Al} \mathrm{s}$ & $\mathrm{O}$ ar que soltou, o gás carbônico & $\begin{array}{l}\text { Organizando } \\
\text { informacões }\end{array}$ \\
\hline 279 & Pr II & $\begin{array}{l}\text { Quem acha que é? Outra coisa? } \\
\text { Vocês lembram o que a gente } \\
\text { estudou sobre o indicador ácido } \\
\text {-base }\end{array}$ & \\
\hline 280 & Al 1 & $\begin{array}{l}\text { Vocês jogaram gás carbônico ali } \\
\text { dentro e fecharam o tubinho. }\end{array}$ & $\begin{array}{c}\text { Levantamento de } \\
\text { hipóteses }\end{array}$ \\
\hline 281 & Pr II & $\begin{array}{l}\text { Nós não fechamos junto? } \\
\text { Fechamos aqui com vocês. }\end{array}$ & \\
\hline 282 & Pr I & $\begin{array}{l}\text { Tá até gravado ali. A gente não } \\
\text { mexeu mais ali. Não } \\
\text { manipulamos isso. }\end{array}$ & \\
\hline 283 & Pr II & $\begin{array}{l}\text { Lembra lá do experimento que } \\
\text { sopramos, o canudinho. Quando }\end{array}$ & \\
\hline
\end{tabular}




\begin{tabular}{|c|c|c|c|}
\hline & & $\begin{array}{l}\text { vocês sopraram, vocês liberam o } \\
\text { que? }\end{array}$ & \\
\hline 284 & $\mathrm{Al} \mathrm{s}$ & Gás carbônico & $\begin{array}{l}\text { Organizando } \\
\text { Informações }\end{array}$ \\
\hline 285 & Pr III & $\begin{array}{l}\text { Aí o gás carbono entrou em } \\
\text { contato com a água, fez uma } \\
\text { reação química que fez o acido. } \\
\text { Aí mudou pra que cor? }\end{array}$ & \\
\hline 286 & $\mathrm{Al} \mathrm{s}$ & Laranja & $\begin{array}{l}\text { Organizando } \\
\text { informações }\end{array}$ \\
\hline 287 & Pr III & $\begin{array}{l}\text { Então nós temos o vidro } \\
\text { tampado que tá laranja né? }\end{array}$ & \\
\hline 288 & Pr III & $\begin{array}{l}\text { Tentem pensar só na situação. O } \\
\text { que tem que ser parecido com o } \\
\text { outro pra ficar igual. }\end{array}$ & \\
\hline 289 & Pr II & $\begin{array}{l}\text { Pra ele ficar laranja ele tem que } \\
\text { ficar o que? Pensa assim }\end{array}$ & \\
\hline 290 & Al 6 & Ele tem que ter ácido & $\begin{array}{l}\text { Organizando } \\
\text { informações }\end{array}$ \\
\hline 291 & Pr III & $\begin{array}{l}\text { Aí a gente produziu o ácido } \\
\text { com o gás carbono que a gente } \\
\text { liberou soprando na água. Não } \\
\text { foi? }\end{array}$ & \\
\hline 292 & Al 1 & $\begin{array}{l}\text { Eu acho que ela ( a planta) jogou } \\
\text { isso na água. }\end{array}$ & $\begin{array}{l}\text { Levantamento de } \\
\text { hipóteses }\end{array}$ \\
\hline 293 & Pr II & $\begin{array}{l}\text { Jogou? Como ela joga isso na } \\
\text { água? }\end{array}$ & \\
\hline 294 & Aluno? & liberou o ácido & $\begin{array}{l}\text { Levantamento de } \\
\text { hipóteses }\end{array}$ \\
\hline 295 & Pr II & E como você forma o ácido? & \\
\hline 296 & $\mathrm{Al} 4$ & Soprando na água & \\
\hline 297 & Pr II & $\begin{array}{l}\text { Soprando na água. Como que a } \\
\text { planta então liberaria isso? }\end{array}$ & \\
\hline 298 & Al 13 & $\begin{array}{l}\text { Aqui dentro do tubinho tinha o } \\
\text { ar? }\end{array}$ & \\
\hline
\end{tabular}




\begin{tabular}{|c|c|c|c|}
\hline Turno & Participante & Fala do Participante & Indicadores de A.C \\
\hline 299 & Pr II & $\begin{array}{l}\text { Isso! o ar que você tampou, que } \\
\text { ficou aí dentro }\end{array}$ & \\
\hline 300 & Al 13 & $\begin{array}{l}\text { Tinha o ar dentro do vidro. Aí a } \\
\text { planta respirou esse ar }\end{array}$ & Explicação \\
\hline 301 & Pr II & Tá continua & \\
\hline 302 & Al 13 & $\begin{array}{l}\text { Aí ela respirou, transformou em } \\
\text { gás carbono e soltou }\end{array}$ & Explicação \\
\hline 303 & Al 12 & $\begin{array}{l}\text { Tipo, ela pegou o ar que tava } \\
\text { dentro do vidrinho. Daí se fosse } \\
\text { isso quando a gente pegasse a } \\
\text { planta e colocasse ele já ficava, } \\
\text { porque demorou um pouquinho } \\
\text { pra gente pegar e fechar com o } \\
\text { papel alumínio, senão já teria } \\
\text { ficado já laranja }\end{array}$ & Explicação \\
\hline 304 & Pr II & $\begin{array}{l}\text { Você acha que esse tempinho } \\
\text { daria pra mudar? }\end{array}$ & \\
\hline 305 & Al 12 & Sim & \\
\hline 306 & Pr II & $\begin{array}{l}\text { E alguém? Tem mais alguma } \\
\text { opinião? }\end{array}$ & \\
\hline 307 & Al 15 & $\begin{array}{l}\text { eu acho que é por causa da } \\
\text { lâmpada ainda }\end{array}$ & $\begin{array}{l}\text { Levantamento de } \\
\text { hipóteses }\end{array}$ \\
\hline 308 & Al 1 & $\begin{array}{l}\text { eu acho que a planta respirou } \\
\text { primeiro }\end{array}$ & $\begin{array}{l}\text { Levantamento de } \\
\text { hipóteses }\end{array}$ \\
\hline
\end{tabular}




\begin{tabular}{|c|c|c|c|}
\hline Turno & Participante & Fala do Participante & Indicadores de A.C \\
\hline 309 & Pr III & $\begin{array}{l}\text { : Vamos só pegar um pouquinho } \\
\text { de cada coisa interessante. Por } \\
\text { exemplo: falaram que a luz tem } \\
\text { influência, se tá aberto ou tá } \\
\text { fechado tem influência, outra } \\
\text { questão que colocaram aqui pra } \\
\text { gente é que soltou o gás carbônico } \\
\text { e o gás carbônico em contato com } \\
\text { a água vira o ácido carbônico e o } \\
\text { ácido mudou a cor, não foi? E } \\
\text { agora mudou a cor também. } \\
\text { Mudou a cor pq? Ele disse } \\
\text { (apontando para o aluno) que } \\
\text { tinha oxigênio ali dentro, a planta } \\
\text { respirou ou seja, puxou o oxigênio } \\
\text { e soltou o quê? O gás carbônico. } \\
\text { E misturando gás carbônico com } \\
\text { água vai acontecer o quê? }\end{array}$ & \\
\hline 310 & Al 3 & Virou ácido, ficou amarelo & Explicação \\
\hline 311 & Pr III & $\begin{array}{l}\text { beleza! Agora eu vou perguntar: } \\
\text { porque que aqui não? Porque esse } \\
\text { que a gente não tampou não } \\
\text { ficou? }\end{array}$ & \\
\hline 312 & Al 1 & Porque esquentou & $\begin{array}{l}\text { Levantamento de } \\
\text { hipóteses }\end{array}$ \\
\hline 313 & Pr III & Se tem luz acontece o quê? & \\
\hline 314 & Al s & A fotossíntese & $\begin{array}{l}\text { Organizando } \\
\text { informações }\end{array}$ \\
\hline 315 & Pr III & Se não tem luz? & \\
\hline 316 & Als & Não acontece nada & \\
\hline 317 & Pr III & $\begin{array}{l}\text { Então quer dizer que aqui não } \\
\text { tem fotossíntese? ( professor } \\
\text { mostra o tubo que foi coberto com } \\
\text { papel alumínio). }\end{array}$ & \\
\hline 318 & Als & Não & $\begin{array}{l}\text { Organizando } \\
\text { Informações }\end{array}$ \\
\hline 319 & Pr III & Aqui tem só o que? & \\
\hline 320 & Al 6 & Respiração & $\begin{array}{l}\text { Organizando } \\
\text { Informações }\end{array}$ \\
\hline 321 & Pr III & A respiração pessoal & \\
\hline
\end{tabular}




\begin{tabular}{|c|c|c|c|}
\hline Turno & Participante & Fala do Participante & Indicadores de A.C \\
\hline 322 & Pr III & $\begin{array}{l}\text { E aqui? (professor levanta o } \\
\text { tubo de ensaio que ficou sem o } \\
\text { papel alumínio) }\end{array}$ & \\
\hline 323 & $\mathrm{Al} \mathrm{s}$ & A fotossíntese & $\begin{array}{l}\text { Organizando } \\
\text { Informações }\end{array}$ \\
\hline 324 & Pr III & $\begin{array}{l}\text { Só a fotossíntese aqui? Quando } \\
\text { ele faz fotossíntese ele para de } \\
\text { respirar? }\end{array}$ & \\
\hline 325 & $\mathrm{Al} \mathrm{s}$ & Não & $\begin{array}{l}\text { Organizando } \\
\text { Informações }\end{array}$ \\
\hline 326 & Pr III & Então teve o que aqui? Inaudível & \\
\hline 327 & Pr III & $\begin{array}{l}\text { Os dois. Então eu pergunto. Se } \\
\text { teve os dois porque não mudou } \\
\text { tanto de cor? O que acontece na } \\
\text { fotossíntese? }\end{array}$ & \\
\hline 328 & Pr I & Pensam só nos gases aqui & \\
\hline 329 & Pr I & $\begin{array}{l}\text { Ó A planta respira a todo } \\
\text { momento? }\end{array}$ & \\
\hline 330 & $\mathrm{Al} \mathrm{s}$ & Sim & \\
\hline 331 & Pr I & $\begin{array}{l}\text { Vamos explicar isso mais } \\
\text { detalhadamente: }\end{array}$ & \\
\hline 332 & Pr I & $\begin{array}{l}\text { Na fotossíntese o que que mais } \\
\text { tem aqui de reagente? ( } \\
\text { professor na lousa), além de } \mathrm{co}_{2} \\
\text { o que que precisa pra fazer a } \\
\text { fotossíntese? }\end{array}$ & \\
\hline 333 & Al 1 & Luz & $\begin{array}{l}\text { Seriação de } \\
\text { Informações }\end{array}$ \\
\hline 334 & $\mathrm{Al} 6$ & Água & $\begin{array}{l}\text { Seriação de } \\
\text { Informações }\end{array}$ \\
\hline 335 & Al 8 & Clorofila & $\begin{array}{l}\text { Seriação de } \\
\text { Informações }\end{array}$ \\
\hline 336 & Pr I & $\begin{array}{l}\text { E os produtos? Clorofila é } \\
\text { importante também! Produz } \\
\text { oxigênio e o que? }\end{array}$ & \\
\hline 337 & $\mathrm{Al} 3$ & Glicose & $\begin{array}{l}\text { Seriação de } \\
\text { Informações }\end{array}$ \\
\hline
\end{tabular}




\begin{tabular}{|c|c|c|c|}
\hline Turno & Participante & Fala do Participante & Indicadores de A.C \\
\hline 338 & Pr I & $\begin{array}{l}\text { A glicose! Vocês lembram que a } \\
\text { glicose é o açúcar que ela } \\
\text { produz? }\end{array}$ & \\
\hline 340 & $\mathrm{Al} \mathrm{s}$ & Sim & \\
\hline 341 & Pr I & $\begin{array}{l}\text { Tá! Ó! Vamos analisar a } \\
\text { fotossíntese. A fotossíntese ela } \\
\text { permite a planta a fazer o quê? }\end{array}$ & \\
\hline 342 & Al 3 & $\mathrm{O}$ alimento & $\begin{array}{l}\text { Organizando } \\
\text { Informações }\end{array}$ \\
\hline 343 & Pr I & $\begin{array}{l}\text { Vocês falaram assim fazer seu } \\
\text { próprio alimento, produzir o } \\
\text { próprio alimento, o alimento } \\
\text { não é a glicose? }\end{array}$ & \\
\hline 344 & Pr I & $\begin{array}{l}\text { Vocês acham que esse alimento } \\
\text { tem energia? }\end{array}$ & \\
\hline 345 & Al 3 & Sim & \\
\hline 346 & Pr I & $\begin{array}{l}\text { Tem né! Porque que a gente } \\
\text { come? }\end{array}$ & \\
\hline 347 & Al 6 & Pra ter energia & $\begin{array}{l}\text { Organizando } \\
\text { Informações }\end{array}$ \\
\hline 348 & Pr I & $\begin{array}{l}\text { Pra ter energia, pra ter } \\
\text { nutrientes, principalmente } \\
\text { energia. Então esse aqui sendo o } \\
\text { alimento da planta esse alimento } \\
\text { tem energia. Mas de onde vem } \\
\text { essa energia? }\end{array}$ & \\
\hline 349 & $\mathrm{Al} 12$ & $\begin{array}{l}\text { Professor, mas professor essa } \\
\text { folha como ela não está mais na } \\
\text { árvore supõe que ela esteja } \\
\text { morta. }\end{array}$ & \\
\hline 350 & Pr I & Humm! & \\
\hline 351 & Al 12 & Ela não está morta? & \\
\hline 352 & Pr I & $\begin{array}{l}\text { A folha quando a gente arrança } \\
\text { da árvore ela ainda tem } \\
\text { capacidade de fazer fotossíntese }\end{array}$ & \\
\hline
\end{tabular}




\begin{tabular}{|c|c|c|c|}
\hline Turno & Participante & Fala do Participante & Indicadores de A.C \\
\hline 353 & $\operatorname{Pr}$ II & $\begin{array}{l}\text { Durante um tempo. Depois ela } \\
\text { murcha e acaba morrendo }\end{array}$ & \\
\hline 354 & Pr I & $\begin{array}{l}\text { A tendência é ela morrer daqui a } \\
\text { pouquinho! Mas pó enquanto tá } \\
\text { tudo funcionando. }\end{array}$ & \\
\hline \multirow[t]{2}{*}{355} & \multirow[t]{2}{*}{ Al 6} & \multirow{2}{*}{$\begin{array}{l}\text { Bom! Na minha hipótese é que } \\
\text { nessa( aluna aponta para o tubo } \\
\text { de ensaio) como ela recebeu a } \\
\text { luz ela fez a fotossíntese normal } \\
\text { e ela não liberou } \mathrm{Co}_{2} \text { então não } \\
\text { fez a mistura que deu no ácido. } \\
\text { Já nessa ( aluna aponta para o } \\
\text { outro tubo de ensaio), ela só } \\
\text { respirou porque ela não tinha luz } \\
\text { ela só respirou o que liberou o } \\
\text { gás carbônico que com a junção } \\
\text { da água virou ácido. }\end{array}$} & $\begin{array}{l}\text { Levantamento de } \\
\text { hipóteses }\end{array}$ \\
\hline & & & Justificativa \\
\hline 356 & Pr III & $\begin{array}{l}\text { Mas a de cá ( apontando para o } \\
\text { tubo de ensaio que estava sem } \\
\text { papel alumínio) vc acha que } \\
\text { nunca libera gás carbônico? }\end{array}$ & \\
\hline 357 & Al 6 & $\begin{array}{l}\text { Essa ... liberou porque ela } \\
\text { respirou também. }\end{array}$ & Explicação \\
\hline 358 & Pr III & $\begin{array}{l}\text { E o que que ela fez com esse gás } \\
\text { Carbônico? }\end{array}$ & \\
\hline 359 & Pr III & $\begin{array}{l}\text { Pensem! O que que ela fez com } \\
\text { esse gás carbônico }\end{array}$ & \\
\hline 360 & Al 6 & A fotossíntese & Explicação \\
\hline 361 & Pr III & $\begin{array}{l}\text { Precisa do gás carbônico pra } \\
\text { fazer a fotossíntese? }\end{array}$ & \\
\hline 362 & Al 6 & Sim & \\
\hline 363 & Pr II & Você percebeu? & \\
\hline 364 & $\mathrm{Al} 6$ & $\begin{array}{l}\text { Ah entendi! Ela respirou e } \\
\text { também fez a fotossíntese }\end{array}$ & Explicação \\
\hline
\end{tabular}




\begin{tabular}{|c|c|c|c|}
\hline Turno & Participante & Fala do Participante & Indicadores de A.C \\
\hline 365 & Pr III & Então explica pro pessoal! & \\
\hline 366 & $\mathrm{Al} 6$ & $\begin{array}{l}\text { Tá. Nessa aqui ( aponta para os } \\
\text { tubos) }\end{array}$ & \\
\hline 367 & Pr II & $\begin{array}{l}\text { Pode levantar (aluna levanta a } \\
\text { estante com os tubos de ensaio) }\end{array}$ & \\
\hline 368 & Pr II & Só os tubinhos & \\
\hline 369 & Al 6 & $\begin{array}{l}\text { As duas plantas respiram, por } \\
\text { isso essa tá mais clara. Mas essa } \\
\text { recebeu luz, então ela teve como } \\
\text { fazer a fotossíntese, ao contrário } \\
\text { dessa. }\end{array}$ & Explicação \\
\hline 370 & Pr III & $\begin{array}{l}\text { E o que acontece na } \\
\text { fotossíntese? Alguém mais pode } \\
\text { explica? }\end{array}$ & \\
\hline 371 & Al 3 & Ela liberou o oxigênio & Explicação \\
\hline 372 & Pr II & E usou o que? A luz... & \\
\hline 373 & Al 3 & O gás Carbônico & Explicação \\
\hline 374 & Pr III & $\begin{array}{l}\text { Se ela usou o gás carbônico } \\
\text { sobrou gás carbônico pra fazer o } \\
\text { ácido carbônico? }\end{array}$ & \\
\hline 375 & Al 3 & $\begin{array}{l}\text { Não!já quando ela respira ela } \\
\text { consome o oxigênio e libera o } \\
\text { gás carbônico. }\end{array}$ & Explicação \\
\hline
\end{tabular}




\begin{tabular}{|c|c|c|c|}
\hline Turno & Participante & Fala do Participante & Indicadores de A.C \\
\hline 376 & Al 3 & $\begin{array}{l}\text { Assim ela tá certa! (aponta para } \\
\text { outra aluna) quando ela faz } \\
\text { fotossíntese ela vai usar o gás } \\
\text { carbônico e liberar o oxigênio, já } \\
\text { quando ela só respira ela vai usar } \\
\text { o oxigênio e liberar o gás } \\
\text { carbônico, aí estando em contato } \\
\text { com a água mudou a cor. }\end{array}$ & Justificativa \\
\hline 377 & Pr III & $\begin{array}{l}\text { Mas porque a diferença na cor? } \\
\text { Porque um ficou com cor e outro } \\
\text { ficou mais claro. }\end{array}$ & \\
\hline 378 & Al 3 & $\begin{array}{l}\text { É porque essa ( pegou os tubos) } \\
\text { fez a fotossíntese e respirou e } \\
\text { essa só respirou. }\end{array}$ & Explicação \\
\hline 379 & Pr III & $\begin{array}{l}\text { Se não fez a fotossíntese, não } \\
\text { usou o que? }\end{array}$ & \\
\hline 380 & Al 3 & O gás carbônico & Explicação \\
\hline 381 & Pr III & Entenderam? & \\
\hline 382 & $\mathrm{Al} \mathrm{s}$ & Sim & \\
\hline 383 & Pr I & $\begin{array}{l}\text { Agora nós vamos escrever o que } \\
\text { fizemos no caderno. }\end{array}$ & \\
\hline
\end{tabular}

Quadro 13 - Os turnos e os indicadores de Alfabetização Científica identificados no episódio 2 da etapa de interpretação e discussão dos resultados do experimento.

Neste longo episódio verificamos a presença de Indicadores de Alfabetização Científica em vários turnos (Quadro 13). Os alunos estavam comprometidos em resolver o problema proposto pelos professores. Nesse sentido estebeleceram um diálodo em sala que permitiu a classificação desses turnos de fala nos seguintes indicadores de Alfabetização Científica: organizar informações, seriar informações, fazer previsões, constatações, levantarem hipóteses, para no final conseguir justificar e explicar a alteração da cor. 


\begin{tabular}{|l|c|}
\hline \multicolumn{1}{|c|}{$\begin{array}{c}\text { Indicadores de Alfabetização } \\
\text { Científica }\end{array}$} & $\begin{array}{c}\text { Turnos de fala em que determinado } \\
\text { indicador aparece }\end{array}$ \\
\hline Organização de informação & 20 \\
\hline Constatação & 2 \\
\hline Seriação de informação & 6 \\
\hline Previsão & 4 \\
\hline Levantamento de Hipóteses & 23 \\
\hline Justificativa & 9 \\
\hline Explicação & 22 \\
\hline Raciocínio lógico & 2 \\
\hline
\end{tabular}

Quadro 14 - Quantidade de turnos em que cada indicador aparece na etapa 3 


\section{CAPÍTULO 4 - ANÁLISES E DISCUSSÕES}

Analisando os episódios apresentados no capítulo anterior, constatou-se a presença de Indicadores de Alfabetização Científica na etapa "Manipulação e Montagem do Experimento - Fase A e B" e na etapa "Interpretação e Discussão dos Resultados da Atividade Experimental”. A partir da observação de um gráfico comparativo, percebemos que a frequência de indicadores em cada etapa foi diferente (Tabela 1 e Gráfico 1).

\begin{tabular}{|c|c|c|c|c|c|c|c|c|}
\hline \multirow{2}{*}{ Indicadores } & \multicolumn{2}{|c|}{ Etapa 1} & \multicolumn{2}{|c|}{ Etapa 2 Fase $\mathbf{A}$} & \multicolumn{2}{|c|}{ Etapa 2} & \multicolumn{2}{|l|}{ Etapa 3} \\
\hline & № absoluto & Frequência & $\begin{array}{l}\text { № } \\
\text { absoluto }\end{array}$ & Frequência & $\begin{array}{l}\text { № } \\
\text { absoluto }\end{array}$ & Frequência & $\begin{array}{l}\text { № } \\
\text { Absoluto }\end{array}$ & Frequência \\
\hline Constatação & 0 & 0 & 9 & 90 & & & 2 & 2,272727273 \\
\hline Seriação de Informações & 0 & 0 & 0 & 0 & & & 6 & 6,818181818 \\
\hline Organização de informações & 0 & 0 & 1 & 10 & 2 & 11,11111111 & 20 & 22,72727273 \\
\hline Raciocínio Lógico & 0 & 0 & 0 & 0 & & & 2 & 2,272727273 \\
\hline Levantamento de hipóteses & 0 & 0 & 0 & 0 & 4 & 22,22222222 & 23 & 26,13636364 \\
\hline Justificativas & 0 & 0 & 0 & 0 & 3 & 16,66666667 & 9 & 10,22727273 \\
\hline Explicação & 0 & 0 & 0 & 0 & 3 & 16,66666667 & 22 & 25 \\
\hline Aquisição de dados & 0 & 0 & 0 & 0 & 1 & 5,555555556 & & 0 \\
\hline Previsão & 0 & 0 & 0 & 0 & 5 & 27,77777778 & 4 & 4,545454545 \\
\hline Total & 0 & 0 & 10 & 100 & 37 & 100 & 88 & 100 \\
\hline
\end{tabular}

Tabela 1 - Frequência em que os indicadores de Alfabetização Científica ocorrem em cada uma das etapas da aula 


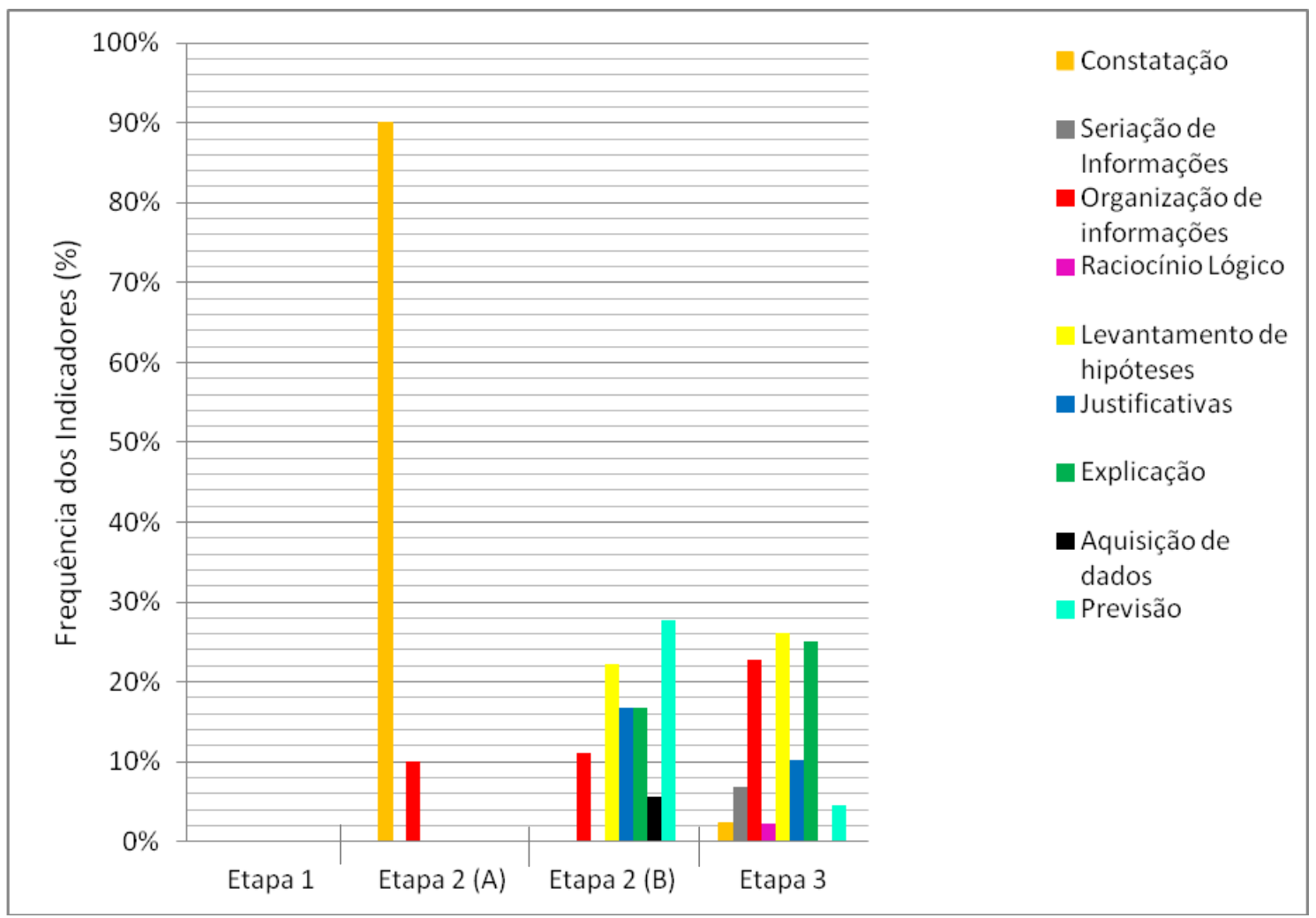

Gráfico 1 - Comparação entre a frequência de Indicadores presentes em cada etapa

A atividade prática experimental analisada apresentou três etapas distintas. A etapa 1 é uma etapa caracterizada pelo levantamento de conhecimentos prévios. A etapa 2 é uma etapa de contato com o material utilizado no experimento e a etapa 3 é destinada a interpretação dos resultados experimentais.

Etapa 1- Levantamentos de Conhecimentos Prévios: não foi identificado Indicadores de Alfabetização Científica. Considerando que os indicadores são habilidades próprias do fazer científico, desenvolvido pelos alunos durante uma atividade, neste momento inicial, a atividade experimental ainda não oportunizou aos alunos desenvolverem tais habilidades, portanto nesta etapa não foi definido nenhum indicador de Alfabetização Científica.

O objetivo nesta etapa da atividade era que os alunos expressassem suas concepções sobre o assunto que seria abordado na atividade.

Estudos apontam que os novos conhecimentos são arranjados a partir dos conhecimentos já existentes. ( PIAGET, 1977; VIGOTSKI, 2002). 
Mortimer (2000) pontua que a partir dos conhecimentos prévios, outros conhecimentos podem ser integrados, resultando num acervo denominado por este autor como perfil conceitual.

O levantamento de conhecimentos prévios também é apontado por Carvalho, et al.; (2013.p.9), como parte constitutiva das sequências didáticas investigativas.

Nesse contexto teórico é que propomos as sequências de ensino investigativas (SEIS), isto é, sequência de atividades (aulas) abrangendo um tópico do programa escolar em que cada atividade é planejada, do ponto de vista do material e das interações didáticas, visando proporcionar aos alunos: condições de trazer seus conhecimentos prévios para iniciar os novos, terem ideias próprias e poder discuti-las com seus colegas e com o professor passando do conhecimento espontâneo ao científico e adquirindo condições de entenderem conhecimentos já estruturados por gerações anteriores. (grifo nosso)

Observando o gráfico verificamos que na etapa 2- Manipulação do material e montagem do experimento, ocorreram o Indicador de Alfabetização CientíficaConstatação na fase A ( Entrando em contato com os materiais) e os Indicadores Aquisição de Informações, Levantamento de Hipóteses, Justificativa, Explicação, Previsão, na fase B ( Resolvendo problemas utilizando conhecimentos sobre o material).

O Indicador Constatação apresentou-se com uma frequência de $90 \%$ na fase $\mathrm{A}$ da etapa 2. Este indicador esteve relacionado a momentos em que o contato sensorial com o material possibilitou aos estudantes receberem e extraírem informações do meio. Nesta atividade os estudantes estabeleceram um contato sensorial com uma substância química, um indicador ácido-base utilizado na montagem do experimento.

Muitos experimentos propostos para o ensino fundamental utilizam substâncias que demandam um conhecimento da área química, os quais os estudantes nesta faixa etária ainda não tiveram contato. A título de exemplificação, além do experimento proposto nesta atividade, temos os experimentos relacionados à área de fisiologia, como aqueles que trabalham com digestão na boca, estômago e intestino. Nestes experimentos, é comum os professores considerarem a presença dessas substâncias como coadjuvantes no experimento, já que o foco está no experimento biológico. Nesse sentido, é comum os professores apenas citarem a utilização dessas substâncias químicas, não realizando nenhum trabalho específico com tais elementos. É possível que os alunos não consigam interpretar os resultados do experimento biológico proposto 
pelo professor por não entenderem como funciona o componente químico utilizado no experimento.

Neste sentido, temos que essa fase nas atividades experimentais não deve ser negligenciada, uma vez que essa etapa propicia o desenvolvimento de habilidades peculiares do fazer científico, como o indicador Constatação, apresentado em nosso trabalho e também por viabilizar a compreensão do experimento biológico, como veremos adiante quando analisarmos a frequência dos indicadores presentes na etapa 3 .

Já na etapa 2- fase B, encontramos exclusivamente a presença do indicador “Aquisição de dados", este indicador aparece quando os alunos estão envolvidos com o reconhecimento dos materiais e com a montagem do experimento. É neste momento da atividade que os alunos propõem metodologias para buscar dados para a situação investigada. Consideramos que atividades experimentais investigativas que tenham um cuidado com essa etapa da atividade favoreçam o desenvolvimento desta habilidade pelos alunos. Ainda na etapa 2, fase B, observamos uma alta frequência do indicador previsão.

O trabalho realizado com o componente químico na fase A, possibilitou que os alunos realizassem várias previsões sobre o comportamento deste indicador, enquanto solucionava o problema proposto na fase B.

$\mathrm{Na}$ etapa 3 é possível verificar que as habilidades definidas por Sasseron e Carvalho (2008) como aquelas relacionadas ao entendimento da situação analisada são muito frequentes. É o caso das habilidades Levantamento de Hipóteses e Explicação.

Outro aspecto relevante que os nossos dados apontam é o fato das habilidades desenvolvidas pelos alunos na terceira etapa da aula, está vinculada com o desenvolvimento da etapa anterior.

O turno 346 representa esse vínculo entre a etapa 2 e a etapa 3.

\begin{tabular}{|l|l|l|}
\hline 376 & Al 3 & $\begin{array}{l}\text { Assim ela tá certa! (aponta para } \\
\text { outra aluna) quando ela faz } \\
\text { fotossíntese ela vai usar o gás } \\
\text { carbônico e liberar o oxigênio, já } \\
\text { quando ela só respira ela vai usar } \\
\text { o oxigênio e liberar o gás } \\
\text { carbônico, aí estando em contato } \\
\text { com a água mudou a cor. }\end{array}$ \\
\hline
\end{tabular}


Este turno presente na etapa 3 (Interpretação e Resolução do Problema), o aluno utiliza os conceitos aprendidos na etapa 2 para formular sua explicação. $\mathrm{O}$ aluno ao realizar sua explicação para o problema proposto utiliza na frase ... liberar o gás carbônico, aí estando em contato com a água mudou a cor.

O turno demonstra que o aluno compreende que as plantas estão realizando o processo de respiração e que neste processo é liberado o gás carbônico e que a junção deste gás com a solução é o que provoca a mudança de cor do indicador.

O mesmo é visto no turno 355.

\begin{tabular}{|l|l|l|c|}
\hline 355 & Al 6 & $\begin{array}{l}\text { Bom! Na minha hipótese é que } \\
\text { nessa( aluna aponta para o tubo } \\
\text { de ensaio) como ela recebeu a } \\
\text { luz ela fez a fotossíntese normal } \\
\text { e ela não liberou co } \text { então não }_{2} \\
\text { fez a mistura que deu no ácido. } \\
\text { Já nessa ( aluna aponta para o } \\
\text { outro tubo de ensaio), ela só } \\
\text { respirou porque ela não tinha luz } \\
\text { ela só respirou o que liberou o } \\
\text { gás carbônico que com a junção } \\
\text { da água virou ácido. }\end{array}$ & \multicolumn{1}{|c|}{$\begin{array}{c}\text { Explicação } \\
\text { hipóteses }\end{array}$} \\
\cline { 2 - 4 } & & Justificativa \\
\hline
\end{tabular}

Neste turno em que o aluno desenvolveu habilidades como levantamento de hipóteses, explicação e justificativa. Observamos novamente uma retomada da etapa anterior.

... e ela não liberou $\mathrm{co}_{2}$ então não fez a mistura que deu no ácido. Já nessa ( aluna aponta para o outro tubo de ensaio), ela só respirou porque ela não tinha luz ela só respirou o que liberou o gás carbônico que com a junção da água virou ácido.

Semelhante ao que foi observado no turno 376 o aluno mais uma vez retoma o que foi discutido e analisado na etapa anterior para formular sua explicação.

Podemos inferir que o aluno entende que a alteração da cor do indicador de $\mathrm{pH}$ está relacionado ao processo de respiração do vegetal, que liberando $\mathrm{co}_{2}$, esse gás formase um ácido quando junta-se com a solução e altera a cor do indicador.

Dessa forma temos que o desenvolvimento das habilidades, explicação, levantamento de hipóteses, justificativa presentes na etapa 3, de resolução do problema, está diretamente relacionado com execução da etapa 2. 
O Indicador Organização de informações também aparece com bastante frequência nesta etapa, a presença deste indicador indica que a todo o momento os alunos retomam as informações vista na etapa 1 (Levantamento de Conhecimentos Prévios) e na etapa 2 (Manipulação de Materiais e Montagem do Experimento). Como verificado nos seguintes turnos:

\begin{tabular}{|l|l|l|l|}
\hline 341 & Pr I & $\begin{array}{l}\text { Tá! Ó! Vamos analisar a } \\
\text { fotossíntese. A fotossíntese ela } \\
\text { permite a planta a fazer o quê? }\end{array}$ & \\
\hline 342 & Al 3 & O alimento & $\begin{array}{l}\text { Organizando } \\
\text { Informações }\end{array}$ \\
\hline
\end{tabular}

\begin{tabular}{|l|l|l|l|}
\hline 289 & Pr II & $\begin{array}{l}\text { Pra ele ficar laranja ele tem que } \\
\text { ficar o que? Pensa assim }\end{array}$ & \\
\hline 290 & Al 6 & Ele tem que ter ácido & $\begin{array}{l}\text { Organizando } \\
\text { informações }\end{array}$ \\
\hline
\end{tabular}

No turno 342 os alunos retomam as discussões que realizaram no inicio da aula, na etapa de Levantamento de Conhecimentos Prévios. A reorganização destas informações são fundamentais na estruturação dos novos conhecimentos.

Já no turno 290 os aluno organizam informações obtidas na etapa 2.

Consideramos que a alta frequência do indicador organização de informação nesta etapa da atividade experimetal seja um indicativo que as etapas da atividade experimental investigativa são concatenadas. E que a resolução do problema está diretamente associada à execução das etapas anteriores.

O gráfico também indica a presença do indicador constatação na etapa 3. A presença deste turno é muito representativa, pois os alunos desenvolvem de forma autônoma a habilidade Constatação. O contato sensorial com os tubos de ensaio, oportuniza o aluno a extrair informações de forma simular ao que foi realizado na etapa 2, contudo neta etapa a ação parte do aluno. 


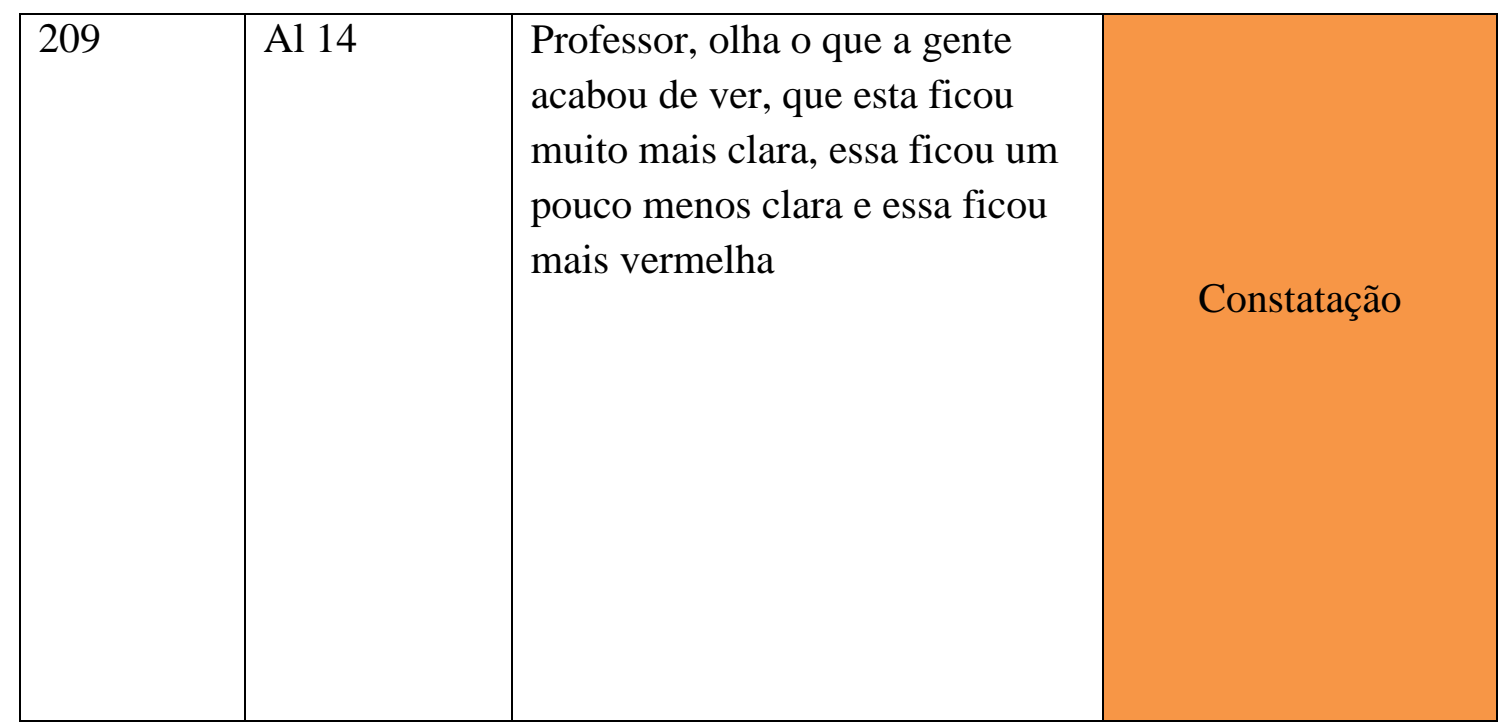

A partir de nossas análises inferimos que as três estapas estão concatenadas e desenvolvem habilidades requeridas na promoção da Alfabetização Científica.

Nossos dados apontam também que a Alfabetização Científica pode ser favorecida em situações em que o nível de autonomia do aluno não é tão grande. Se fossemos classificar essa atividade de acordo com os níveis de liberdade proposto por Carvalho (2006), ela se enquadraria no nível 2. Neste nível a elaboração da atividade é realizada pelo professor e ainda assim, é possível como constatado pela atividade, observar aspectos que são próprios da cultura cientíca. Nesse sentido esta atividade vai de encontro com as colocações Munford e Lima (2007) que afirmam ser um equívoco acreditar que a atividade experimental investigativa deve ficar totalmente sob responsabilidade do aluno. Concordamos com as autoras supracitas principalmente quando nos referimos às atividades experimentais desenvolvidas no ensino fundamental, quando a faixa etária dos alunos é menor. 


\section{CONSIDERAÇÕES}

Retomando nossa pergunta de pesquisa "Como são as aulas experimentais, no contexto do ensino por investigação, que promovem a Alfabetização Científica?”, apresentamos algumas considerações.

A atividade analisada neste trabalho viabilizou o desenvolvimento de habilidades próprias do fazer científico, favorecendo, portanto o processo de Alfabetização Científica.

Nesse sentido nossos dados indicam que a ocorrência de tais indicadores está relacionada à maneira como a atividade foi planejada pelos professores.

Observamos que o planejamento da atividade apresentou um momento para o levantamento de conhecimentos prévios, outro destinado ao reconhecimento, entendimento e manuseio de todas as substâncias utilizadas na atividade experimental, e ainda, uma etapa em que foi possível os alunos analisarem e discutirem os dados experimentais. Muitas das atividades experimentais executadas negligenciam uma ou mais destas etapas. Verificamos que a execução de todas estas etapas oportunizou a resolução do problema pelos alunos.

Pontuamos que, o trabalho com as substâncias utilizadas nos experimentos na maioria das vezes é considerada coadjuvante na atividade. Verificamos, porém que o trabalho realizado com a subtância química nesta atividade foi imprescindível na resolução do problema proposto pelos professores. Outro aspecto relevante é o fato deste contato ter possibilitado o desenvolvimento de uma habilidade específica, indicando que esta etapa, além de ser importante para a resolução do problema, contribuiu para o desenvolvimento de habilidades específicas.

A condução de todas estas etapas se caracterizou por não considerar os alunos como meros receptores de informações. Diferente de uma abordagem tradicional, na qual aos alunos caberia apenas à ação manipulativa, na atividade em questão, ações reflexivas prevaleceram em relação às ações mecânicas. A condução desta aula experimental investigativa priorizou o processo de reflexão dos alunos sobre o objeto de estudo e forneceu condições para os alunos expressarem seus pontos de vista, envolvendo-os de forma mais efetiva no processo de aprendizagem. 
Dessa forma concluímos que a atividade experimental no contexto investigativo, apresenta peculiaridades quanto ao planejamento e execução, para que possa, de fato, viabilizar o processo de Alfabetização Científica.

Um fator relevante a ser apontado é o fato de a aula experimental ter sido elaborada por professores em formação. Possibilitar que estes professores entrem em contato com a cultura científica e reconheçam a importância no processo de ensino de ciências é fundamental para a efetivação do processo de Alfabetização Científica. 


\section{REFERÊNCIAS}

ANDRADE, M. L. F.; MASSABNI, V. G. O desenvolvimento de atividades práticas na escola: umdesafio para os professores de ciências. Ciência \& Educação, Bauru, v. 17, n. 4, p. 835-854, 2011.Disponível em: <http://dx.doi.org/10.1590/S151673132011000400005>. Acesso em: 06 ago. 2012.

AULER, D.; DELIZOCOV, D. Alfabetização científico-técnológicas para quê? Ensaio: Pesuisa em Educação em Ciências. 3:105-115.2001.

AXT, R. O papel da experimentação no ensino de Ciências. In: MOREIRA, M. A.; AXT, R. Tópicos em ensino de Ciências. Porto Alegre: Sagra, 1991.

BARROW, L. H. A Brief History of Inquiry: From Dewey to Standards. Journal of Science TeacherEducation, v. 17, n. 3, p. 265-278, 2006.

BASSOLI, F. Atividades práticas e o ensino-aprendizagem de ciência(s): mitos, tendências e distorções. Ciência \& Educação., Bauru, v. 20, n. 3, p. 579-593, 2014.

BRASIL. Ministério da Educação. Secretaria de Educação Fundamental. Parâmetros Curriculares Nacionais: Ciências $\left(3^{\circ}\right.$ e $4^{\circ}$ ciclos do ensino fundamental). Brasília: MEC, 1998.

CACHAPUZ, A.; GIL-PÉREZ, D.; CARVAlHO, A. M. P; VIlChES, A. A Necessária Renovação do Ensino de Ciências. São Paulo: Cortez, 2005.

CAPECCHI, M. C. M.; CARVALHO, A. M. P. Atividades de laboratório como instrumentos para a abordagem de aspectos da cultura científica em sala de aula. Proposições, v. 17, n. 1, p. 137-353, 2006. Disponível em: < http://moodle.stoa.usp.br/file.php/1197/Capecchi_e_Carvalho_2006.pdf $>$. Acesso em: 19 de Fevereiro de 2015.

CARVALHO, A. M. P. Las practices experimentales en el proceso de enculturación cientifica . In: GATICA, M Q; ADÚRIZ-BRAVO, A (Ed). Enseñar ciencias en el Nuevo milenio: retos e propuestas. Santiago: Universidade católica de Chile.2006.

- Habilidades de professores para promover a enculturação científica.

Contexto \& Educação, v.22, n.77, p.25-49, 2007. Disponível em: <https://www.revistas.unijui.edu.br/index.php/contextoeducacao/article/view/1084/839

$>$. Acesso em: 5 de Janeiro de 2015.

Construindo argumentação na sala de aula: a presença do ciclo argumentativo, os indicadores de alfabetização científica e o padrão de toulmin. Ciência 
e Educação, Bauru, v. 17, n.1, p. 97-114, 2011. Disponível em: < http://www.scielo.br/pdf/ciedu/v17n1/07.pdf>. Acesso em: 13 de novembro de 2014.

.(Org) Ensino de Ciências por Investigação: condições para a

implementação em sala de aula. São Paulo: Cengage Learning, 2013.

CARVALHO, A. M. P., TINOCO, S. C. O Ensino de Ciências como "enculturação". In: Catani, D. B.; Vicentini, P. P. (Orgs). Formação e Autoformação: Saberres e Práticas nas Experiências dos Professores. São Paulo: Escrituras, 2006.

FILHO, B. B. Atividades Práticas na 8a Série do Ensino Fundamental: luz numa abordagem regionalizada. Dissertação (Mestrado em Educação) - Faculdade de Educação, Universidade de Campinas (UNICAMP), Campinas, 2001.

GALIAZZI, M. C.; ROCHA, J. M. B.; SCHMITZ, L. C.; SOUZA, M. L.; GIESTA, S.; GONÇALVES, F. P. Objetivos das atividades experimentais no Ensino Médio: a pesquisa coletiva como modo de formação de professores de Ciências. Ciência \& Educação, v.7, n.2, p. 249-263, 2001. Disponível em: < http://www.scielo.br/pdf/ciedu/v7n2/08.pdf>. Acesso em: 10 de novembro de 2014.

GIL PEREZ, D. VALDES CASTRO, P. La orientación de las practices de laboratorio como invetigagación: un ejemplo ilustrativo. Enseñanza de las ciencias, 14 (2), 1996.

GODOY, A. S. Introdução á pesquisa qualitativa e suas possibilidades. Revista de Administração de Empresas, v.35, n.2, p. 57-63, 1995. Disponível em: < http://www.scielo.br/pdf/rae/v35n2/a08v35n2.pdf >. Acesso em: 20 de novembro de 2014.

HODSON, D. Hacia un enfoque más crítico del trabajo de la laboratorio. Enseñanza de las Ciencias, v.12, n.3, p. 299-313, 1994.

JIMÉNEZ-ALEIXANDRE, M. P. La Catástrofe del Prestige: Racionalidad Crítica versus Racionalidad Instrumental. Cultura y Educación, v.16, n.3, p. 305-319, 2004.

JUNQUEIRA, N. E. G. Ensino de Fisiologia Vegetal. 1. Ed. Novas Edições Acadêmicas, 2014.

KAWASAKI, C. S.; BIZZO, N. M. V. Fotossíntese, um tema para o ensino de ciências? Química Nova na Escola, São Paulo, n.12, p. 24-29, 2000. Disponível em: < http://qnesc.sbq.org.br/online/qnesc12/v12a06.pdf>. Acesso em: 15 de novembro de 2014.

KRASILCHIK, M. Prática de ensino de biologia. 4. ed. São Paulo: Edusp, 2004. 197 p.

KRASILCHIK, M. Reformas e Realidade: o caso do ensino de Ciencias. São Paulo em Perspectiva,v.14,n.1,p.85-93,2000. 
MAMEDE, M.; ZIMMERMANN, E. Letramento Científico e CTS na formação de Professores para o ensino de ciências. Enseñanza de las ciencias, 2005. Número Extra. Disponível em: <http://ddd.uab.cat/pub/edlc/edlc_a2005nEXTRA/edlc_a2005nEXTRAp320letcie.pdf>. Acesso em: 19 de fevereiro de 2015.

MORENO B., M. G. (2002). Formación para la investigación centrada en el desarrollo de habilidades. Guadalajara: Universidad de Guadalajara.

MORTIMER, E. F. Linguagem e formação de conceitos no ensino de ciências. Belo Horizonte: UFMG, 2002. Reimpresso em 2006.

MORTIMER, E. F.; CARVALHO, A. M. P. Referenciais teóricos para análise do processo de ensino deCiências. Cadernos de Pesquisa, São Paulo, n. 96, p. 5-14,1996.

MORTIMER, E. F.; MASSICAME, T.; TIBERGHIEN, A.; BUTY, C. Uma metodologia para caracterizar os gêneros de discurso como tipos de estratégias enunciativas nas aulasde ciências. In: NARDI, R. A pesquisa em ensino de ciência no Brasil: alguns recortes. São Paulo: Escrituras, p.53-94, 2007.

MUNFORD, D.; LIMA, M. E. C. C. Ensinar ciências por investigação: em que estamos de acordo?Ensaio: pesquisa em educação em ciências, Belo Horizonte, v. 9, n. 1, p. 72-89, 2007. Disponível em: < http://www.portal.fae.ufmg.br/seer/index.php/ensaio/article/view/122/172>. Acesso em: 06 ago. 2014.

PENHA, S. P.; CARVALHO, A. M. P.; VIANNA, D. M.; A utilização de atividades investigativas em uma proposta de enculturação científica: Novos indicadores para análise do processo. In: Encontro Nacional de Pesquisa em Educação em Ciências, VII, 2009, Atas, Universidade Federal de Santa Catarina (Florianópolis), 2009, p. 1-12.

PIAGET, J. Psicologia da inteligência. Rio de Janeiro: Zahar, 1977.

PRAIA, J. F.; CACHAPUZ, A.; GIL-PÉREZ, D. A hipótese e a experiência científica em educação em ciências: contributos para uma reorientação epistemológica. Ciência \& Educação, v.8, n.2, p. 253-262, 2002. Disponível em: < http://www.scielo.br/pdf/ciedu/v8n2/09.pdf>. Acesso em: 8 de dezembro de 2014.

PRETI, D. Sociolinguística Os níveis de fala: Um estudo Sociolinguístico do Diálogo na Literatura Brasileira. São Paulo: Edusp, 2003.

RABONI, P. C. A. Atividades Práticas de Ciências aturais na Formação de Professores Para as Séries Iniciais. Tese (Doutorado em Educação) - Faculdade de Educação, Universidade de Campinas, (UNICAMP), Campinas, 2002. 
RAMOS, L. B. C.; ROSA, P. R. S. O ensino de ciências: fatores intrínsecos e extrínsecos que limitam a realização de atividades experimentais pelo professor dos anos iniciais do ensino fundamental. Investigações em Ensino de Ciências, v. 13, n.3, p.299-331, 2008. Disponível em: < http://www.if.ufrgs.br/ienci/artigos/Artigo_ID197/v13_n3_a2008.pdf>. Acesso em: 15 de dezembro de 2014.

SASSERON, L. H.; CARVALHO, A. M. P. Almejando a alfabetização científica no ensinofundamental: a proposição e a procura de indicadores do processo. Investigações em Ensino de Ciências, Porto Alegre, v. 13, n. 3, p. 333-352, 2008. Disponível em: < http://www.if.ufrgs.br/ienci/artigos/Artigo_ID199/v13_n3_a2008.pdf >. Acesso em: 3 de novembro de 2014.

SILVA, A.C.T. Estratégias enunciativas em salas de aula de química: contrastando professores de estilos diferentes. 2008. 367f. Tese de Doutorado-Universidade Federal de Minas Gerais, Belo Horizonte, 2008.

SILVA, A.C.T; MORTIMER, E.F. Caracterizando estratégias enunciativas em uma sala de aula de química: aspectos teóricos e metodológicos em direção à configuração de um gênero do discurso. Investigações em Ensino de Ciências. v.15,n.1, p. 121-153. 2010.

SILVA, L. H. A.; ZANON, L. B. A experimentação no ensino de ciências. In: SCHNETZLER, R.P.; ARAGÃO, R. M. R. Ensino de Ciências: fundamentos e abordagens. Piracicaba: CAPES/UNIMEP, p.120-153, 2000.

TRÓPIA, G. B. A. Percursos históricos de ensinar ciências através de atividades investigativas.Ensaio: pesquisa em educação em ciências, Belo Horizonte, v. 13, n. 1, p. 121-138, 2011. Disponível em: <http://www.portal.fae.ufmg.br/seer/index.php/ensaio/article/viewArticle/245>. Acesso em: 09 ago. 2014.

VYGOTSKY, L. S. Formação social da mente. Trad.: J. C. Neto, L. S. M. Barreto, S. C. Afeche. $6^{\circ}$ ed. São paulo: Martins Fontes, 2002.

ZÔMPERO, A. F.; LABURU, C. E. Atividades investigativas no ensino de ciências: aspectos históricos e diferentes abordagens. Ensaio: pesquisa em educação em ciências, Belo Horizonte, v. 13, n. 3, p. 67-80, 2011. Disponível em: <http://www.portal.fae.ufmg.br/seer/index.php/ensaio/article/view/309/715>. Acesso em: 
ANEXOS

\section{$\underline{\text { Transcricão da Aula Experimental }}$}

\begin{tabular}{|c|c|c|}
\hline Turno & Participante & Fala do Participante \\
\hline 1 & $\operatorname{Pr} I$ & $\begin{array}{l}\text { Pessoal, pessoal presta atenção aqui um pouquinho! } \\
\text { Ó vocês tiveram umas aulas com microscópio, lupa, foi } \\
\text { legal né ? : Hoje infelizmente não tem nem microscópio } \\
\text { nem lupa, mas a gente trouxe uma coisa muito legal pra } \\
\text { mostrar pra vocês. } \\
\text { É perguntaram pra mim se isso aqui era sangue; Não, } \\
\text { não é sangue, daqui a pouquinho nós vamos ver o que } \\
\text { que é isso. }\end{array}$ \\
\hline 2 & Al 1 & É vinagre \\
\hline 3 & Pr I & Não é vinagre, é porque vocês viram vinagre aqui. \\
\hline 4 & $\mathrm{Al} 2$ & É sangue de baleia! \\
\hline 5 & $\operatorname{Pr} I$ & $\begin{array}{l}\text { Hoje a aula é sobre fotossíntese. Vocês sabem o que é } \\
\text { fotossíntese? }\end{array}$ \\
\hline 6 & Al 1 & $\begin{array}{l}\text { É... é quando a planta usa os raios do sol pra se } \\
\text { alimentar }\end{array}$ \\
\hline 7 & $\mathrm{Al} 3$ & Ela produz seu próprio alimento \\
\hline 8 & Pr I & $\begin{array}{l}\text { Alguém mais quer falar alguma coisa sobre } \\
\text { fotossíntese? O que que vocês lembram? } \\
\text { Vocês já viram em alguma aula isso daqui? }\end{array}$ \\
\hline 9 & $\mathrm{Al} \mathrm{s}$ & Sim:: \\
\hline 10 & $\mathrm{Al} 4$ & $\mathrm{Na}$ aula de microscópio \\
\hline 11 & $\mathrm{Al} \mathrm{s}$ & (risos) \\
\hline
\end{tabular}




\begin{tabular}{|c|c|l|}
\hline 12 & Al 5 & $\begin{array}{l}\text { Fotossíntese é o processo em que a planta faz seu } \\
\text { próprio alimento. }\end{array}$ \\
\hline 13 & Pr I & A planta faz; animal faz fotossíntese? \\
\hline 14 & Al s & Não :: \\
\hline & Então ó . A planta faz \\
(Professor coloca na lousa palavras-chaves que os Al s \\
falaram sobre fotossíntese) \\
Planta, que mais vocês falaram?
\end{tabular}




\begin{tabular}{|c|c|c|}
\hline 26 & $\mathrm{Al} 6$ & Glicose \\
\hline 27 & $\operatorname{Pr} I$ & Glicose. Ó perfeito \\
\hline 28 & Pr III & E o que é glicose? \\
\hline 29 & Al 7 & Açucar! \\
\hline 30 & Al 6 & É a comida da planta \\
\hline 31 & Pr I & $\begin{array}{l}\text { Hoje nós vamos fazer um experimento de fotossíntese, } \\
\text { tá? E o que, que esse liquido vermelho tem a ver com } \\
\text { experimento? A gente vai usar ele pra detectar alguma } \\
\text { coisa no experimento. Tá? ( Os Al s estavam sentados } \\
\text { em grupos e em cada grupo tinha uma estante com um } \\
\text { tubo de ensaio contendo vermelho de cresol)( nesse } \\
\text { momento os professores distribuem canudinhos para os } \\
\text { Al s) ó alguém do grupo vai ter que soprar esse líquido } \\
\text { que tá aqui. Só que cuidado porque se vocês colocarem } \\
\text { aqui e soprar (professor mostra o tubo de ensaio) com } \\
\text { muita força, vai voltar na cara de vocês. } \\
\text { Então começa soprar desde aqui de cima, vai descendo } \\
\text { devagarzinho até chegar no líquido. Faz vamo ver o que } \\
\text { vai acontecer? Ó aquele que for soprar segura em cima, } \\
\text { deixa o liquido visível pra todo mundo, tá ! tem que } \\
\text { ficar vendo o líquido. Não tomem isso. } \\
\text { (Al s assopram) }\end{array}$ \\
\hline 32 & Pr I & Pessoal e aí. Aconteceu alguma coisa? \\
\hline 33 & $\mathrm{Al} \mathrm{s}$ & Mudou de cor, ficou amarelo \\
\hline 34 & Pr I & Mudou de cor! Que cor que ficou? \\
\hline 35 & $\mathrm{Al} \mathrm{s}$ & Amarelo \\
\hline
\end{tabular}




\begin{tabular}{|c|c|c|}
\hline 36 & $\operatorname{Pr} I$ & $\begin{array}{l}\text { Cada grupo levanta para todo mundo ver! Ficou da } \\
\text { mesma cor? Ficou igual? }\end{array}$ \\
\hline 37 & $\mathrm{Al} \mathrm{s}$ & Ficou \\
\hline 38 & $\operatorname{Pr} I$ & Então que cor que era? \\
\hline 39 & $\mathrm{Al} \mathrm{s}$ & Vermelho \\
\hline 40 & Pr I & Ficou amarelo? \\
\hline 41 & $\mathrm{Al} \mathrm{s}$ & Sim:: \\
\hline 42 & Pr I & $\begin{array}{l}\text { Então... Esse líquido vermelho chama vermelho de } \\
\text { cresol. (professor escreve na lousa) }\end{array}$ \\
\hline 43 & Pr I & $\begin{array}{l}\text { O que que é esse vermelho de cresol? Ele é uma } \\
\text { substância que a gente chama de indicador ácido -base } \\
\text { tá? O que que o indicador ácido-base faz? É uma } \\
\text { substancia colorida que quando a gente taca o ácido ou } \\
\text { uma base ela vai mudar de cor. Ééé... Limão é ácido? }\end{array}$ \\
\hline 44 & $\mathrm{Al} \mathrm{s}$ & Sim:: \\
\hline 45 & $\operatorname{Pr} I$ & Vinagre é ácido? \\
\hline 46 & $\mathrm{Al} \mathrm{s}$ & Sim:: \\
\hline 47 & $\operatorname{Pr} I$ & $\begin{array}{l}\text { Então ó, vinagre (professor mostra o frasco de vinagre) } \\
\text { eu vou tacar aqui (no tubo de ensaio que contém } \\
\text { vermelho de cresol) no indicador ácido - base. Igual eu } \\
\text { falei. Quando a gente taca um ácido no indicador ácido } \\
\text {-base vai mudar de cor. (professor coloca vinagre no } \\
\text { frasco com vermelho de cresol) }\end{array}$ \\
\hline 48 & $\mathrm{Al} \mathrm{s}$ & Nossa::. Que legal? \\
\hline
\end{tabular}




\begin{tabular}{|c|c|c|}
\hline 49 & Pr I & Ficou igual o que vocês sopraram? \\
\hline 50 & $\mathrm{Al} \mathrm{s}$ & Sim \\
\hline 51 & Pr I & Ó vinagre é um ácido. Uma base é... \\
\hline 52 & $\mathrm{Al} 4$ & O que que é isso que você tem na mão? \\
\hline 53 & Pr I & $\begin{array}{l}\text { Isso aqui é uma base é soda caustica, você sabe o que é? } \\
\text { Geralmente seus pais podem usar pra desentupir pia. }\end{array}$ \\
\hline 54 & $\mathrm{Al} 2$ & Fazer sabão \\
\hline 55 & Pr I & Fazer sabão. \\
\hline 56 & $\mathrm{Al} 8$ & Como é que chama professor? \\
\hline 57 & Pr I & $\begin{array}{l}\text { Soda Cáustica. A soda cáustica ela é uma base tá? É um } \\
\text { grupo de substâncias que a gente chama de base em } \\
\text { química. Quando a gente taca uma base no vermelho de } \\
\text { cresol ele muda de cor também. (professor coloca soda } \\
\text { cáustica no vermelho de cresol) }\end{array}$ \\
\hline 58 & $\mathrm{Al} \mathrm{s}$ & Nossa! Que bonito \\
\hline 59 & Pr I & $\begin{array}{l}\text { Então olha só! Era vermelho, a cor dele mesmo, aí } \\
\text { quando você taca um ácido que cor que fica? }\end{array}$ \\
\hline 60 & $\mathrm{Al} \mathrm{s}$ & Amarelo- alaranjado \\
\hline 61 & Pr I & E quando você taca uma base? \\
\hline 62 & $\mathrm{Al} \mathrm{s}$ & Roxo \\
\hline 63 & Pr I & Vamos anotar isso? \\
\hline 64 & $\mathrm{Al} 4$ & Professor, essa aula tá da hora viu. \\
\hline
\end{tabular}




\begin{tabular}{|c|c|c|}
\hline 65 & Al 1 & Professor, como é que faz a substancia? \\
\hline 66 & Pr I & O vermelho de cresol, a gente... \\
\hline 67 & $\mathrm{Al} 2$ & $\begin{array}{l}\text { Professor aquilo que você pois pra ficar roxo não é } \\
\text { soda? }\end{array}$ \\
\hline 68 & $\operatorname{Pr} I$ & É sim \\
\hline 69 & $\mathrm{Al} 2$ & Te falei menina chata \\
\hline 70 & $\operatorname{Pr} I$ & $\begin{array}{l}\text { Vermelho de cresol a gente compra pronto. Ele vem em } \\
\text { pozinho aí a gente mistura na água e fica assim. Tá? } \\
\text { Esse aqui a gente pegou na USP. }\end{array}$ \\
\hline 71 & $\mathrm{Al} 6$ & E porque quando a gente soprou mudou de cor? \\
\hline 72 & Pr III & Boa pergunta! \\
\hline 73 & $\operatorname{Pr} I$ & $\begin{array}{l}\text { Ó podem anotar no caderno ( a anotação que o professor } \\
\text { fez na lousa) Vermelho de cresol indicador ácido - base, } \\
\text { quando coloca ácido fica amarelo, quando coloca base } \\
\text { fica roxo. }\end{array}$ \\
\hline 74 & Pr III & $\begin{array}{l}\text { A pergunta dela é a seguinte: Quando colocou o vinagre } \\
\text { aqui que é ácido ficou...? }\end{array}$ \\
\hline 75 & $\mathrm{Al} \mathrm{s}$ & Amarelo. \\
\hline 76 & Pr III & $\begin{array}{l}\text { E porque quando ela soprou ficou amarelo? Ela soprou } \\
\text { um bafo de vinagre (risos) }\end{array}$ \\
\hline 77 & $\mathrm{Al} \mathrm{s}$ & (risos), Não:: \\
\hline 78 & Al 1 & Ela soprou gás carbônico \\
\hline
\end{tabular}




\begin{tabular}{|c|c|c|}
\hline 79 & Pr III & $\begin{array}{l}\text { Ela soprou gás carbônico. E o que aconteceu quando ela } \\
\text { soprou gás carbônico? }\end{array}$ \\
\hline 80 & Al 1 & Misturou? \\
\hline 81 & Pr III & $\begin{array}{l}\text { Vamos lá, Quando ela soprou soltou gás carbônico, o } \\
\text { gás carbônico junto com a água se transforma num } \\
\text { ácido, o ácido carbônico. E o que acontece quando o } \\
\text { vermelho de cresol tem contato com ácido? }\end{array}$ \\
\hline 82 & Al s & Fica laranja. \\
\hline 83 & Pr III & $\begin{array}{l}\text { Então olha o que aconteceu. Quando o professor1 } \\
\text { misturou vinagre no vermelho de cresol ele fez uma } \\
\text { reação química, quando vocês sopraram vocês fizeram } \\
\text { duas reações. Primeiro o gás carbônico em contato com } \\
\text { a água se transformou num ácido, depois esse ácido } \\
\text { modificou, ocorreu duas reações. }\end{array}$ \\
\hline 84 & Al 5 & Professor do que que o ácido é feito? \\
\hline 85 & Pr I & $\begin{array}{l}\text { Ela perguntou assim: do que que o ácido é feito? Na } \\
\text { verdade é assim, é uma classe de substâncias químicas } \\
\text { né, que tem umas propriedades em comum, né, assim } \\
\text { até tem um sabor em comum, o vinagre, o limão não } \\
\text { tem um sabor azedinho. Tem ácido que corroem coisas, } \\
\text { mas assim a gente não vai entrar em muitos detalhes } \\
\text { aqui porque isso é química de colegial. Mas hoje o que } \\
\text { que a gente precisa saber, existe substâncias como o } \\
\text { vermelho de cresol e não é só ele, existe várias } \\
\text { substâncias que tem essa propriedade. Que propriedade } \\
\text { é essa? De indicador ácido-base. São substâncias que } \\
\text { mudam a cor dependendo do que a gente taca. Se a } \\
\text { gente taca ácido fica uma cor, se a gente taca base fica } \\
\text { outra cor. É extrato de repolho roxo tem essa } \\
\text { propriedade também, se vocês quiserem pegar repolho } \\
\text { fazer, cozinhar ele na água né extrair aquele roxinho do } \\
\text { repolho roxo, e aí você tacar limão ou vinagre ele vai }\end{array}$ \\
\hline
\end{tabular}




\begin{tabular}{|c|c|c|}
\hline & & mudar de cor também. \\
\hline 86 & Pr II & $\begin{array}{l}\text { Pede pra mãe cozinhar o repolho roxo pra vocês, tem } \\
\text { que sair aquele roxo na água e aí vocês vão fazer a } \\
\text { mesma coisa, coloca em um vidro e coloca limão vai } \\
\text { mudar de cor. }\end{array}$ \\
\hline 87 & Pr I & Funciona do mesmo jeito. Viu! \\
\hline 88 & Al 9 & Eu queria saber que vinagre e sal é um ácido, não é. \\
\hline 89 & Pr III & Vinagre e limão. \\
\hline 90 & Al 9 & $\begin{array}{l}\text { Limão? Ah, porque eu fiz uma experiência que pegou o } \\
\text { vinagre, sal e uma moeda e aí a moeda mudou de cor. }\end{array}$ \\
\hline 91 & Pr III & $\begin{array}{l}\text { Nesse caso é um outro tipo de reação química. É uma } \\
\text { reação química de oxidação. É uma outra coisa, é um } \\
\text { outro tipo de reação química. Vou tentar explicar de } \\
\text { forma bem simples. Vocês vão ver mais pra frente. }\end{array}$ \\
\hline 92 & Pr III & $\begin{array}{l}\text { Aconteceu uma reação química que a gente chama de } \\
\text { oxidação, o oxigênio que estava ali começou a se } \\
\text { desgrudar e mudou a cor da moeda, isso de uma maneira } \\
\text { bem simplificado. } \\
\text { Dá pra você ter uma ideia da diferença: }\end{array}$ \\
\hline 93 & Al 9 & Dá sim \\
\hline 94 & Pr I & $\begin{array}{l}\text { Ó isso aqui vocês entenderam? ( professor aponta pra } \\
\text { lousa). }\end{array}$ \\
\hline 95 & $\mathrm{Al} \mathrm{s}$ & Sim:: \\
\hline
\end{tabular}




\begin{tabular}{|c|c|c|}
\hline 96 & Pr I & $\begin{array}{l}\text { Entenderam que o indicador ácido-base, agente taca } \\
\text { ácido. }\end{array}$ \\
\hline 97 & Al 10 & Fica amarelo. \\
\hline 98 & Pr I & $\begin{array}{l}\text { Isso! Assim ,esse daqui, tem vários indicadores que tem } \\
\text { várias cores, tá, aí quando a gente taca a base fica roxo, } \\
\text { tá. E porque quando a gente soprou ficou } \\
\text { amarelo/laranja? Ó quando fica amarelo/laranja o que eu } \\
\text { é...? }\end{array}$ \\
\hline 99 & $\mathrm{Al} \mathrm{s}$ & Ácido \\
\hline 100 & $\operatorname{Pr} I$ & O que que a gente tava soprando lá? \\
\hline 101 & Pr I & $\begin{array}{l}\text { O gás carbônico, quando eu escrevo } \\
\mathrm{CO}_{2} \text { vocês entendem? ( professor escreve na lousa) }\end{array}$ \\
\hline 102 & $\mathrm{Al} \mathrm{s}$ & Sim:: \\
\hline 103 & $\operatorname{Pr} I$ & $\begin{array}{l}\text { Gás carbônico quando ele entra em contato com a água } \\
\text { ele forma o ácido, que a gente chama de ácido } \\
\text { carbônico, tá. Vocês podem anotar isso daí também. }\end{array}$ \\
\hline 104 & $\operatorname{Pr} I$ & $\begin{array}{l}\text { Não é que a gente fica soprando o ácido, a gente sopra o } \\
\text { co2 e com a água fica ácido. }\end{array}$ \\
\hline 105 & $\operatorname{Pr} I$ & Pessoal vocês já viram gelo seco? \\
\hline 106 & $\mathrm{Al} \mathrm{s}$ & $\begin{array}{l}\text { Não! } \\
\text { (alguns Al s) Já! }\end{array}$ \\
\hline 107 & $\mathrm{Al} 8$ & Já ouvi falar, mas não vi. \\
\hline
\end{tabular}




\begin{tabular}{|c|c|c|}
\hline 108 & $\operatorname{Pr} I$ & Alguém já viu gelo seco? Levantem a mão \\
\hline 109 & $\mathrm{Al} 6$ & É aquele que tem em bebidas? \\
\hline 110 & $\operatorname{Pr} I$ & É as vezes põem em bebidas \\
\hline 111 & $\mathrm{Al} 4$ & se por a mão nele corta né professor \\
\hline 112 & Pr I & $\begin{array}{l}\text { Queima, é muito gelado, não posso nem ficar segurando } \\
\text { muito tempo porque é muito gelado. Você falou quando } \\
\text { coloca na bebida. (professor coloca num Becker). }\end{array}$ \\
\hline 113 & $\mathrm{Al} \mathrm{s}$ & Que legal sai fumaça. \\
\hline 114 & $\operatorname{Pr} I$ & Do que que é feito gelo seco: \\
\hline 115 & Aluno? & Água \\
\hline 116 & Aluno? & $\mathrm{Ar}$ \\
\hline 117 & Al 1 & Nitrogênio \\
\hline 118 & $\operatorname{Pr} I$ & É feito de um gás \\
\hline 119 & $\mathrm{Al} \mathrm{s}$ & Gás Carbônico? \\
\hline 120 & $\operatorname{Pr} I$ & $\begin{array}{l}\text { Isso. Então essa pedrinha que vocês estão vendo é gás } \\
\text { carbônico puro.tá? É um gás na forma de gelo sólido. }\end{array}$ \\
\hline 121 & Pr III & $\begin{array}{l}\text { Vocês conhecem as propriedades da matéria, né? } \\
\text { Sólido, líquido e gasoso,né? }\end{array}$ \\
\hline 122 & $\mathrm{Al} \mathrm{s}$ & Simm \\
\hline 123 & Pr III & O gelo lá na geladeira de casa ele está o que? \\
\hline 124 & $\mathrm{Al} \mathrm{s}$ & Gelado/ Sólido \\
\hline 125 & Pr III & $\begin{array}{l}\text { Gelado e sólido. Se tirar ele e colocar pra fora da } \\
\text { geladeira o que que acontece? }\end{array}$ \\
\hline
\end{tabular}




\begin{tabular}{|c|c|c|}
\hline 126 & $\mathrm{Al} \mathrm{s}$ & Derrete \\
\hline 127 & Pr III & E como vai ficar? \\
\hline 128 & $\mathrm{Al} \mathrm{s}$ & Líquido \\
\hline 129 & Pr III & E se eu aquecer no fogo? \\
\hline 130 & $\mathrm{Al} \mathrm{s}$ & gasoso, ele evapora \\
\hline 131 & Pr III & $\begin{array}{l}\text { Esse gelo seco ele não passa para o estado líquido, ele } \\
\text { vai direto do sólido para o gasoso. }\end{array}$ \\
\hline 132 & $\mathrm{Al} 4$ & Mas como faz? \\
\hline 133 & Pr I & $\begin{array}{l}\text { É uma máquina que faz o gelo seco, não dá pra fazer em } \\
\text { casa. } \\
\text { (professores passam o frasco com gelo seco para os Al } \\
\text { s) }\end{array}$ \\
\hline 134 & Pr I & $\begin{array}{l}\text { Isso daqui que o professor3 falou, ele falou assim passa } \\
\text { do estado sólido... Calma todo mundo vai botar a mão } \\
\text { presta atenção aqui). O que o professor } 3 \text { falou foi assim } \\
\text { ele não derrete e vira água, tá. Ele vai passar do estado } \\
\text { sólido pro líquido, eu vou deixar essa pedrinha aqui de } \\
\text { gelo, aqui vocês vão ver que ele vai sumir e não vão } \\
\text { formar água nenhuma. }\end{array}$ \\
\hline 135 & Al 1 & $\begin{array}{l}\text { Professor uma pergunta. E se agente jogar uma pedra } \\
\text { nesse negócio aí. (aponta para o vermelho de cresol) }\end{array}$ \\
\hline 136 & Pr I & Boa! O que você acha que vai acontecer? \\
\hline 137 & Al 1 & Vai evaporar, vai mudar de cor. \\
\hline 138 & Pr III & Vai evaporar, vai mudar de cor, que mais? \\
\hline
\end{tabular}




\begin{tabular}{|c|c|c|}
\hline 139 & Al 9 & Vai sair bolhas \\
\hline 140 & Pr III & Qual cor vocês acham que vai ficar? \\
\hline 141 & $\mathrm{Al} 4$ & Vai ficar roxo \\
\hline 142 & Al 1 & Vai ficar amarelo \\
\hline 143 & Pr III & $\begin{array}{l}\text { Um falou que vai ficar roxo o outro falou que vai ficar } \\
\text { amarelo, alguém sabe explicar porque da mudança de } \\
\text { cor? }\end{array}$ \\
\hline 144 & $\mathrm{Al} 3$ & Amarelo, Por causa do gás carbônico \\
\hline 145 & Pr I & $\begin{array}{l}\text { E o que aconteceu quando vocês colocaram gás } \\
\text { carbônico aqui ( vermelho de cresol). }\end{array}$ \\
\hline 146 & $\mathrm{Al} \mathrm{s}$ & Mudou de cor \\
\hline 147 & Pr III & Que cor \\
\hline 148 & $\mathrm{Al} \mathrm{s}$ & Laranja/ amarelo \\
\hline 149 & Pr III & Que cor vai ficar ali \\
\hline 150 & $\mathrm{Al} \mathrm{s}$ & Laranja/amarelo \\
\hline 151 & Pr III & Por quê? \\
\hline 152 & $\mathrm{Al} \mathrm{s}$ & Por causa do gás carbônico \\
\hline 153 & Pr III & Ele vai ficar ácido em contato com a água. \\
\hline 154 & Pr I & $\begin{array}{l}\text { Vamos prestar atenção aqui. Nós íamos colocar o gelo } \\
\text { seco aqui dentro(vermelho de cresol). }\end{array}$ \\
\hline 155 & $\mathrm{Al} \mathrm{s}$ & Nossa que legal. Mudando de cor. \\
\hline
\end{tabular}




\begin{tabular}{|c|c|c|}
\hline 156 & $\operatorname{Pr} I$ & Porque ficou amarelo? \\
\hline 157 & $\mathrm{Al} 6$ & Por causa do gás carbônico, queé um ácido \\
\hline 158 & Pr III & O gás carbônico não é um ácido \\
\hline 159 & $\mathrm{Al} 6$ & $\begin{array}{l}\text { Desculpa! Por causa do gás carbônico que se junta com } \\
\text { a água e fica ácido }\end{array}$ \\
\hline 160 & Pr III & Isso mesmo \\
\hline & & $\begin{array}{l}\text { Professores distribuem } 3 \text { tubos de ensaio por mesa, cada } \\
\text { tubo continha um pouco de vermelho de cresol. Em um } \\
\text { dos tubos foi colocado uma folha e tampado com papel } \\
\text { filme na abertura, no outro tubo foi feito o mesmo } \\
\text { procedimento só que cobrimos todo o tubo com papel } \\
\text { alumínio, e no terceiro tubo apenas tamparam a abertura } \\
\text { com papel filme.) } \\
\text { ( Os Al s desenharam no caderno o que acabaram de } \\
\text { fazer) Todos os tubos foram colocados perto de uma luz } \\
\text {, que estava dentro da mesma sala) }\end{array}$ \\
\hline 161 & Pr I & $\begin{array}{l}\text { Pessoal, vamos } \\
\text { Vocês lembram o que a gente fez? Pra montar os } \\
\text { tubinhos? Como s gente montou? }\end{array}$ \\
\hline 162 & Al 5 & $\begin{array}{l}\text { Primeiro tinha vermelho de cresol nos potinhos, aí em } \\
\text { um deles a gente só tampou com papel filme, no outro a } \\
\text { gente colocou uma folha e também tampou com esse } \\
\text { papel filme e no terceiro a gente colocou a folha e } \\
\text { colocou papel alumínio }\end{array}$ \\
\hline 163 & Pr I & $\begin{array}{l}\text { Tá, e o que a gente fez depois disso daí, que a gente } \\
\text { montou? Oh, de onde que o PrII tá tirando esses } \\
\text { tubinhos? }\end{array}$ \\
\hline 164 & Al 6 & Dá luz \\
\hline 165 & Pr I & $\begin{array}{l}\text { Então, gente montou isso daí ,e colocou na luz, né. } \\
\text { Vocês lembram o que é esse liquido vermelho, que é o } \\
\text { vermelho de cresol faz? }\end{array}$ \\
\hline 166 & $\mathrm{Al} \mathrm{s}$ & Sim \\
\hline 167 & Pr I & E o que que ele faz \\
\hline 168 & $\mathrm{Al} 6$ & Ele é um indicador ácido-base \\
\hline
\end{tabular}




\begin{tabular}{|c|c|c|}
\hline 169 & Pr I & $\begin{array}{l}\text { Isso, indica ácido-base. Ele pode mudar de cor. Ó o que } \\
\text { vocês acham? Voces tão vendo se aconteceu alguma } \\
\text { coisa aí? ( aponta paraos tubos que estão na mesa dos Al } \\
\text { s) }\end{array}$ \\
\hline 170 & $\mathrm{Al} \mathrm{s}$ & Não \\
\hline 171 & $\operatorname{Pr} I$ & $\begin{array}{l}\text { Antes de abrir! O que vocês acham que aconteceu com o } \\
\text { que estava fechado? }\end{array}$ \\
\hline 172 & $\mathrm{Al} 7$ & Mudou de cor? \\
\hline 173 & Pr I & Mudou de cor \\
\hline 174 & Pr I & $\begin{array}{l}\text { Quem que acha que mudou de cor levanta a mão } \\
\text { ( A maioria dos Al s levantam as mãos) }\end{array}$ \\
\hline 175 & Pr I & $\begin{array}{l}\text { Quem acha que não mudou de cor levanta a mão. ( } \\
\text { poucos Al s levantam as mão) }\end{array}$ \\
\hline 176 & Pr I & $\begin{array}{l}\text { Quem acha que não mudou de cor, por que não mudou } \\
\text { de cor? }\end{array}$ \\
\hline 177 & $\mathrm{Al} 7$ & Porque não entrou luz? \\
\hline 178 & Pr I & $\begin{array}{l}\text { Porque não entrou luz. Que mais? } \\
\text { Ó, eu to perguntando desde daqui especificamente } \\
\text { (PROFESSOR MOSTRA OBJETO PARA OS AL S), } \\
\text { esquecem os outros,. Tem gente que acha mudou de cor, } \\
\text { tem gente que acha que não mudou de cor. Aí ó, você } \\
\text { achou que não mudou de cor porque não entrou luz. } \\
\text { Alguém tem mais alguma hipótese? }\end{array}$ \\
\hline 179 & $\mathrm{Al} 4$ & $\begin{array}{l}\text { Eu tenho professor, daqueles negocinhos que vocês } \\
\text { tavam escrevendo na lousa, ia ficar laranja por causa } \\
\text { do... do ácido }\end{array}$ \\
\hline 180 & Pr I & Mas tem ácido aqui dentro? \\
\hline 181 & $\mathrm{Al} 4$ & Depende da planta \\
\hline 182 & Pr I & $\begin{array}{l}\text { É a mesma planta que aquela lá (professor aponta para o } \\
\text { tubo que está descoberto) Tem ácido aqui dentro? }\end{array}$ \\
\hline 183 & Pr II & $\begin{array}{l}\text { Se tivesse acido nessa planta, teria naquela né? É a } \\
\text { mesma. }\end{array}$ \\
\hline 184 & Pr I & $\begin{array}{l}\text { Então ó! Tem duas opções mudou de cor e não mudou } \\
\text { de cor, aqui não mudou de cor ficou vermelho, agora } \\
\text { tem um monte de gente que falou que mudou de cor. } \\
\text { Porque mudou de cor? }\end{array}$ \\
\hline 185 & Al 11 & Por causa da planta \\
\hline 186 & $\mathrm{Al} 5$ & Porque a planta não tinha luz \\
\hline 187 & Aluno? & Falta de oxigênio \\
\hline
\end{tabular}




\begin{tabular}{|c|c|c|}
\hline 188 & Pr I & Falta de oxigênio. \\
\hline 189 & Al 11 & $\begin{array}{l}\text { Gás Carbônico. A planta liberou gás carbônico, aí ela } \\
\text { fechada não entrou luz, aí eu acho que mudou de cor. }\end{array}$ \\
\hline 190 & Al 6 & $\begin{array}{l}\text { E porque planta libera gás carbônico? É ao contrário ela } \\
\text { libera oxigênio e absorve o gás carbônico. }\end{array}$ \\
\hline 191 & Pr I & $\begin{array}{l}\text { Tava tudo dessa cor (mostrando o tubo de ensaio } \\
\text { controle). Vamos abrir o papel agora, pra gente ver } \\
\text { O que aconteceu. }\end{array}$ \\
\hline 192 & Al s & Nossa! Ficou amarelo/ laranja \\
\hline 193 & Al 3 & $\begin{array}{l}\text { Eu acho que mudou de cor porque ela aqueceu a planta } \\
\text { e ela soltou algum tipo de liquido acido aí mudou a cor }\end{array}$ \\
\hline 194 & Pr I & $\begin{array}{l}\text { É uma hipótese. Alguém tem mais alguma hipótese? } \\
\text { Ó você só vão. Ó, pensa assim, ou mudou de cor ou não } \\
\text { mudou de cor. Mudou de cor. Vocês tem alguma } \\
\text { hipótese porque mudou de cor? }\end{array}$ \\
\hline 195 & Al 11 & Por causa do gás carbônico \\
\hline 196 & $\mathrm{Al} 1$ & A planta criou ácido \\
\hline 197 & $\operatorname{Pr} I$ & $\begin{array}{l}\text { Porque a planta criou ácido, por causa do gás } \\
\text { carbônico. }\end{array}$ \\
\hline 198 & Al 12 & $\begin{array}{l}\text { Professor, é porque aqui ta mostrando que a planta ela } \\
\text { murchou e ela na solta oxigênio? E aqui dentro ta } \\
\text { fechado. Por isso que ela murchou. }\end{array}$ \\
\hline 199 & Pr I & Tá vamos lá \\
\hline 200 & Pr I & $\begin{array}{l}\text { A planta, é só uma parte da planta essa folhas. Posso } \\
\text { fazer isso sem destacar da arvore, deixar ela fora da } \\
\text { arvore, ela não vai murchar também? Porque ela } \\
\text { desidrata, ela perde água }\end{array}$ \\
\hline 201 & Pr I & $\begin{array}{l}\text { É que depende. Depende de como a gente amarrou aí, } \\
\text { depende se ficou mais tempo ou não da luz, porque tem } \\
\text { uma lâmpada amarela, ela é incandescente, ela é quente, } \\
\text { ta? Então se você botar perto do negocio quente, vai } \\
\text { poder desidratar mais ou menos. } \\
\text { Mas vocês acham que foi o calor que fez isso? Que } \\
\text { mudou de cor? }\end{array}$ \\
\hline 202 & $\mathrm{Al} \mathrm{s}$ & Não \\
\hline 203 & Pr I & Assim, porque a gente pode falar que não foi o calor? \\
\hline 204 & Al 13 & Porque ele tava fechado \\
\hline 205 & $\operatorname{Pr} I$ & $\begin{array}{l}\text { Ó, olha só comparando com os outros tubinhos, a gente } \\
\text { consegue justificar que não foi o calor? }\end{array}$ \\
\hline 206 & Pr II & Todas receberam luz? Então se fosse o calor \\
\hline
\end{tabular}




\begin{tabular}{|c|c|c|}
\hline 207 & $\mathrm{Al} 6$ & Todas iam mudar \\
\hline 208 & Pr I & Todas mudariam \\
\hline 209 & Al 14 & $\begin{array}{l}\text { Professor, olha o que a gente acabou de ver, que esta } \\
\text { ficou muito mais clara, essa ficou um pouco menos clara } \\
\text { e essa ficou mais vermelha }\end{array}$ \\
\hline 210 & Pr I & $\begin{array}{l}\text { Legal, ó... das duas que tem plantinhas, uma ficou bem } \\
\text { clara, amarela, laranja e a outra ficou mais ou menos } \\
\text { vermelho claro. }\end{array}$ \\
\hline 211 & Al 9 & $\begin{array}{l}\text { Eu acho que essa daqui que ficou amarela por causa da } \\
\text { luz, porque era a única que tava tampada. E a outra se } \\
\text { tava tampada também ia ficar desse jeito. }\end{array}$ \\
\hline 212 & Pr I & $\begin{array}{l}\text { Tá bom, vamos lá. Vão pensar, ó. (professor pega } \\
\text { tubos de ensaio e mostra para Al s). Este daqui não tinha } \\
\text { planta, ficou do jeito que estava, este daqui tinha planta } \\
\text { e tomou luz, ficou um poquinho laranjado, mas ficou } \\
\text { vermelhinho e essa daqui tinha planta e não tomou luz, } \\
\text { ficou meio amarelo, ta? Que que você falou? (professor } \\
\text { aponta para aluno) }\end{array}$ \\
\hline 213 & $\mathrm{Al} 9$ & $\begin{array}{l}\text { Eu achei que a que não tomou luz, que a que essa fez } \\
\text { diferença, da luz. Porque as outras tomou luz }\end{array}$ \\
\hline 214 & Pr I & $\begin{array}{l}\text { Então quer dizer que o fato de não tomar luz que deixa } \\
\text { amarela? }\end{array}$ \\
\hline 215 & $\mathrm{Al} 6$ & $\begin{array}{l}\text { Será que a falta de luz fez com que a plantinha } \\
\text { murchasse e que ela soltasse algum tipo de acido? }\end{array}$ \\
\hline 216 & Pr I & $\begin{array}{l}\text { A falta de luz fez a plantinha murchar e liberar algum } \\
\text { ácido? } \\
\text { Mas ó.. eu tinha falado sobre desidratação, a planta } \\
\text { murcha quando ta desidradata. O que podia ter } \\
\text { desidratado ali elas? }\end{array}$ \\
\hline 217 & Al s & Calor \\
\hline 218 & Pr I & $\begin{array}{l}\text { Calor ajuda desidratar? Este daqui tava submetido ao } \\
\text { calor também (professor mostra um dos tubos de ensaio) }\end{array}$ \\
\hline 219 & Al 1 & $\begin{array}{l}\text { Será que é por causa da imunidade aí a planta ficou la } \\
\text { que soltou algum gás e fez esse efeito? }\end{array}$ \\
\hline 220 & PrII & E e qual gás é esse \\
\hline 221 & Al 1 & O oxigênio \\
\hline 222 & PrII & $\begin{array}{l}\text { O oxigênio. Pra ela soltar, você fala tampada né? Pra } \\
\text { ela soltar o oxigênio, o que ela tem que ta fazendo? } \\
\text { Heim? O que vocês acham? A planta liberou um gás, }\end{array}$ \\
\hline
\end{tabular}




\begin{tabular}{|c|c|c|}
\hline & & $\begin{array}{l}\text { vamos continuar aqui, a planta liberou um gás, a } \\
\text { tampada, e que é oxigênio que ela liberou né? Foi isso } \\
\text { que ele falou, e ela pra liberar o oxigênio ela tem que ta } \\
\text { fazendo o que? }\end{array}$ \\
\hline 223 & $\mathrm{Al} 6$ & Ela tem que ganhas luz \\
\hline 224 & Al 1 & Ela precisa de coiso de... gás carbônico \\
\hline 225 & PrII & $\begin{array}{l}\text { Então tá... então agora continua. Tem o oxigênio. Tem } \\
\text { outros gases? }\end{array}$ \\
\hline 226 & PrII & $\begin{array}{l}\text { Vocês acham que a planta tampada liberou gás } \\
\text { carbônico ou oxigênio? }\end{array}$ \\
\hline 227 & $\mathrm{Al} \mathrm{s}$ & Oxigênio \\
\hline 228 & $\operatorname{Pr} 2$ & E como ela libera o oxigênio? \\
\hline 229 & Al 5 & Fazendo a fotossíntese \\
\hline 230 & Pr II & E como ela faz fotossíntese? \\
\hline 231 & Al 5 & Quando tem luz \\
\hline 232 & Pr II & E quando não tem luz. Ela faz fotossíntese? \\
\hline 233 & $\mathrm{Al} \mathrm{s}$ & Não \\
\hline 234 & Pr II & $\begin{array}{l}\text { Então ta, a que estava sem tampar nós podemos dizer } \\
\text { que ela estava fazendo fotossíntese? }\end{array}$ \\
\hline 235 & $\mathrm{Al} \mathrm{s}$ & Sim \\
\hline 236 & Pr II & Agora vamos continuar. Vamos por a tampada. \\
\hline 237 & $\operatorname{Pr} I$ & A gente respira? \\
\hline 238 & $\mathrm{Al} \mathrm{s}$ & Sim:: \\
\hline 239 & Pr I & $\begin{array}{l}\text { Oh, respirei, o que eu to colocando no pulmão? } \\
\text { (professor inspira profundamente) }\end{array}$ \\
\hline 240 & $\mathrm{Al} \mathrm{s}$ & Oxigênio \\
\hline 241 & Pr I & Respirei. O que eu to liberando? \\
\hline 242 & $\mathrm{Al} \mathrm{s}$ & Gás carbônico \\
\hline 243 & Pr I & Gás carbônico (professor vai a lousa) \\
\hline 244 & $\operatorname{Pr} I$ & $\begin{array}{l}\text { Se eu escrever assim vocês entendem? (professor } \\
\text { escreve os gases envolvidos na respiração) }\end{array}$ \\
\hline 245 & $\mathrm{Al} \mathrm{s}$ & Sim \\
\hline
\end{tabular}




\begin{tabular}{|c|c|c|}
\hline 246 & $\operatorname{Pr} I$ & $\begin{array}{l}\text { A planta respira, quando ela respira? De dia, de noite, } \\
\text { toda hora? } \\
\text { Ó pensam na gente. A gente respira, quando? }\end{array}$ \\
\hline 247 & $\mathrm{Al} \mathrm{s}$ & Toda hora \\
\hline 248 & $\operatorname{Pr} I$ & Até dormindo? \\
\hline 249 & $\mathrm{Al} \mathrm{s}$ & Sim \\
\hline 250 & Pr I & E a planta? \\
\hline 251 & $\mathrm{Al} \mathrm{s}$ & Também \\
\hline 252 & Pr I & $\begin{array}{l}\text { Oh, a gente ta adicionando uma informação nova pra } \\
\text { vocês criarem novas hipóteses. } \\
\text { Vamos pensar só em gases. A fotossíntese, quais são os } \\
\text { gases pra fazer a fotossíntese? Quais gases precisam? }\end{array}$ \\
\hline 253 & $\mathrm{Al} \mathrm{s}$ & Gás carbônico \\
\hline 254 & Pr I & E assim, que gás é produzido? \\
\hline 255 & $\mathrm{Al} 9$ & Oxigênio \\
\hline 256 & Pr I & $\begin{array}{l}\text { Pra fotossíntese precisa de gás carbônico pra produzir o } \\
\text { oxigênio, não é? Pra respiração você precisa do } \\
\text { oxigênio e produz o gás carbônico. } \\
\text { E aí? Com essas novas informações vocês conseguem } \\
\text { bolar novas hipóteses? }\end{array}$ \\
\hline 257 & $\operatorname{Pr} I$ & Pode falar, são hipóteses. \\
\hline 258 & $\mathrm{Al} 6$ & $\begin{array}{l}\text { Eu tenho uma dúvida. No caso da planta, ela respira a } \\
\text { todo momento, certo? Mas ela, por exemplo, aconteceu } \\
\text { alguma coisa que aí inverteu aí ela absorve o oxigênio e } \\
\text { libera o gás carbônico que juntou com a água e virou } \\
\text { acido carbônico? }\end{array}$ \\
\hline 259 & Pr II & $\begin{array}{l}\text { Então, você acha que numa dessas aí isso aconteceu. Em } \\
\text { qual? }\end{array}$ \\
\hline 260 & $\mathrm{Al} 6$ & Nesta ( aponta para o tubo que ficou tampado \\
\hline 261 & Pr I & Porque? \\
\hline 262 & Al 6 & Porque mudou de cor \\
\hline 263 & $\operatorname{Pr} I$ & $\begin{array}{l}\text { Vocês entenderam o que ela falou? Tenta explicar pra } \\
\text { classe }\end{array}$ \\
\hline 264 & $\mathrm{Al} 6$ & $\begin{array}{l}\text { Assim, pra mim aconteceu alguma coisa nesse tubo de } \\
\text { ensaio que inverteu e a planta ta soltando gás carbônico } \\
\text { que se juntou com a água, que virou acido, que fez } \\
\text { mudar de cor. }\end{array}$ \\
\hline 265 & Pr I & Alguém tem uma hipótese que é diferente dessa? \\
\hline
\end{tabular}




\begin{tabular}{|c|c|c|}
\hline & & \\
\hline 266 & Al 1 & $\begin{array}{l}\text { Que nem, algumas maiorias (oi??) das plantas elas tem } \\
\text { por causa da umidade do ar ela precisam se alimentar, e } \\
\text { pra fazer fotossíntese. Então eu acho que o ar que tava } \\
\text { aqui, ela sugou esse ar que tava aqui dentro esse ar, } \\
\text { soltou gás carbono porque ta embaixo, ai sugou esse gás } \\
\text { carbônico que mudou de cor. }\end{array}$ \\
\hline 267 & Pr I & Sugou gás carbono e devolveu...? \\
\hline 268 & Al 1 & $\begin{array}{l}\text { Devolveu oxigênio, hora que ela sugou o gás carbono... } \\
\text { (inaudível) }\end{array}$ \\
\hline 269 & Pr I & $\begin{array}{l}\text { Ta você ta falando que em algum desses vidrinhos } \\
\text { aconteceu isso. Qual vidrinho você ta falando? }\end{array}$ \\
\hline 270 & Al 1 & Tampado \\
\hline 271 & Pr I & Alguém tem mais alguma hipótese? \\
\hline 272 & Pr II & $\begin{array}{l}\text { Em cima do que ela falou ali, alguém concorda? } \\
\text { Discorda? }\end{array}$ \\
\hline 273 & Pr III & $\begin{array}{l}\text { Pessoal, vamos tentar fazer uma associação. } \\
\text { O que fizeram, lembram do experimento que a gente fez } \\
\text { com o canudinho? }\end{array}$ \\
\hline 274 & $\mathrm{Al} \mathrm{s}$ & Sim \\
\hline 275 & Pr III & Aí a cor ficou parecida com qual? \\
\hline 276 & $\mathrm{Al} \mathrm{s}$ & Com o tampado \\
\hline 277 & Pr III & O que tem de parecido? \\
\hline 278 & $\mathrm{Al} \mathrm{s}$ & $\mathrm{O}$ ar que soltou, o gás carbônico \\
\hline 279 & $\operatorname{Pr} 2$ & $\begin{array}{l}\text { Quem acha que é? Outra coisa? } \\
\text { Vocês lembram o que a gente estou sobre o indicador } \\
\text { ácido -base }\end{array}$ \\
\hline 280 & Al 1 & $\begin{array}{l}\text { Vocês jogaram gás carbônico ali dentro e fecharam o } \\
\text { tubinho }\end{array}$ \\
\hline 281 & Pr II & Nós não fechamos junto? Fechamos aqui com vocês. \\
\hline 282 & $\operatorname{Pr} I$ & $\begin{array}{l}\text { Ta até gravado ali. A gente não mexeu mais ali. Não } \\
\text { manipulamos isso. }\end{array}$ \\
\hline 283 & Pr II & $\begin{array}{l}\text { Lembra lá do experimento que sopramos, o canudinho. } \\
\text { Quando vocês sopraram, você liberam o que? }\end{array}$ \\
\hline
\end{tabular}




\begin{tabular}{|c|c|c|}
\hline 284 & $\mathrm{Al} \mathrm{s}$ & Gás carbônico \\
\hline 285 & Pr III & $\begin{array}{l}\text { AÍ o gás carbono entrou em contato com a água, fez } \\
\text { uma reação química que fez o acido. Aí mudou pra que } \\
\text { cor? }\end{array}$ \\
\hline 286 & $\mathrm{Al} \mathrm{s}$ & Laranja \\
\hline 287 & Pr III & Então nós temos o vidro tampado que tá laranja né? \\
\hline 288 & Pr III & $\begin{array}{l}\text { Tentem pensar só na situação. O que tem que ser } \\
\text { parecido com o outro pra ficar igual. }\end{array}$ \\
\hline 289 & Pr II & $\begin{array}{l}\text { Pra ele ficar laranja ele tem que ficar o que? Pensa } \\
\text { assim }\end{array}$ \\
\hline 290 & Al 6 & Ele tem que ter ácido \\
\hline 291 & Pr III & $\begin{array}{l}\text { Aí a gente produziu o acido com o gás carbono que a } \\
\text { gente liberou soprando na água. Não foi? }\end{array}$ \\
\hline 292 & Al 1 & Eu acho que ela (a planta) jogou isso na água. \\
\hline 293 & Pr II & Jogou? Como ela joga isso na água? \\
\hline 294 & Aluno? & Liberou o acido \\
\hline 295 & Pr II & E como você forma o acido? \\
\hline 296 & $\mathrm{Al} 4$ & Soprando na água \\
\hline 297 & Pr II & $\begin{array}{l}\text { Soprando na água. Como que a planta então liberaria } \\
\text { isso? }\end{array}$ \\
\hline 298 & Al 13 & Aqui dentro do tubinho tinha o ar? \\
\hline 299 & Pr II & Isso! o ar que você tampou, que ficou aí dentro \\
\hline 300 & Al 13 & Tinha o ar dentro do vidro. Aí a planta respirou esse ar \\
\hline 301 & Pr II & Tá continua \\
\hline 302 & Al 13 & Aí ela respirou, transformou em gás carbono e soltou \\
\hline 303 & Al 12 & $\begin{array}{l}\text { Tipo, ela pegou o ar que tava dentro do vidrinho. Daí se } \\
\text { fosse isso quando a gente pegasse a planta e colocasse } \\
\text { ele já ficava, porque demorou um pouquinho pra gente } \\
\text { pegar e fechar com o papel alumínio, senão já teria } \\
\text { ficado já laranja }\end{array}$ \\
\hline
\end{tabular}




\begin{tabular}{|c|c|c|}
\hline 304 & Pr II & Você acha que esse tempinho daria pra mudar? \\
\hline 305 & Al 12 & Sim \\
\hline 306 & Pr II & E alguém? Tem mais alguma opinião? \\
\hline 307 & Al 15 & Eu acho que é por causa da lâmpada ainda \\
\hline 308 & Al I & Eu acho que a planta respirou primeiro. \\
\hline 309 & Pr III & $\begin{array}{l}\text { Vamos só pegar um pouquinho de cada coisa } \\
\text { interessante. Por exemplo: falaram que a luz tem } \\
\text { influência, se tá aberto ou tá fechado tem influência, } \\
\text { outra questão que colocaram aqui pra gente é que soltou } \\
\text { o gás carbônico e o gás carbônico em contato com a } \\
\text { água vira o ácido carbônico e o ácido mudou a cor, não } \\
\text { foi? E agora mudou a cor também. Mudou a cor porque? } \\
\text { Ele disse (apontando para o aluno) que tinha oxigênio } \\
\text { ali dentro, a planta respirou ou seja, puxou o oxigênio e } \\
\text { soltou o quê? O gás carbônico. E misturando gás } \\
\text { carbônico com água vai acontecer o quê? }\end{array}$ \\
\hline 310 & Al 3 & Virou ácido, ficou amarelo \\
\hline 311 & Pr III & $\begin{array}{l}\text { Beleza! Agora eu vou perguntar: porque que aqui não? } \\
\text { Porque esse que a gente não tampou não ficou? }\end{array}$ \\
\hline 312 & Al 1 & Porque esquentou \\
\hline 313 & Pr III & Se tem luz acontece o quê? \\
\hline 314 & $\mathrm{Al} \mathrm{s}$ & A fotossíntese \\
\hline 315 & Pr III & Se não tem luz? \\
\hline 316 & Al s & Não acontece nada \\
\hline 317 & Pr III & $\begin{array}{l}\text { Então quer dizer que aqui não tem fotossíntese? ( } \\
\text { professor mostra o tubo que foi coberto com papel } \\
\text { alumínio). }\end{array}$ \\
\hline 318 & $\mathrm{Al} \mathrm{s}$ & Não \\
\hline 319 & PrIII & Aqui tem só o que? \\
\hline 320 & $\mathrm{Al} 6$ & Respiração \\
\hline 321 & Pr III & A respiração pessoal \\
\hline 322 & Pr III & $\begin{array}{l}\text { E aqui? ( professor levanta o tubo de ensaio que ficou } \\
\text { sem o papel alumínio) }\end{array}$ \\
\hline 323 & Als & A fotossíntese \\
\hline
\end{tabular}




\begin{tabular}{|c|c|c|}
\hline 324 & Pr III & $\begin{array}{l}\text { Só a fotossíntese aqui? Quando ele faz fotossíntese ele } \\
\text { para de respirar? }\end{array}$ \\
\hline 325 & $\mathrm{Al} \mathrm{s}$ & Não \\
\hline 326 & Pr III & Então teve o que aqui? Inaudível \\
\hline 327 & Pr III & $\begin{array}{l}\text { Os dois. Então eu pergunto. Se teve os dois porque não } \\
\text { mudou tanto de cor? O que acontece na fotossíntese? } \\
\text { (Al s ficam quietos) }\end{array}$ \\
\hline 328 & $\operatorname{Pr} I$ & Pensam só nos gases aqui \\
\hline 329 & Pr I & Ó A planta respira a todo momento? \\
\hline 330 & $\mathrm{Al} \mathrm{s}$ & Sim \\
\hline 331 & Pr I & Vamos explicar isso mais detalhadamente: \\
\hline 332 & Pr I & $\begin{array}{l}\text { Na fotossíntese o que que mais tem aqui de reagente? ( } \\
\text { professor na lousa), além de co } 2 \text { o que que precisa pra } \\
\text { fazer a a fotossíntese? }\end{array}$ \\
\hline 333 & Al 1 & Luz \\
\hline 334 & $\mathrm{Al} 6$ & Água \\
\hline 335 & Al 8 & Clorofila \\
\hline 336 & Pr I & $\begin{array}{l}\text { E os produtos? Clorofila é importante também! Produz } \\
\text { oxigênio e o que? }\end{array}$ \\
\hline 337 & $\mathrm{Al} 3$ & Glicose \\
\hline 338 & Pr I & $\begin{array}{l}\text { A glicose! Vocês lembram que a glicose e o açúcar que } \\
\text { ela produz? }\end{array}$ \\
\hline 340 & Al s & Sim \\
\hline 341 & Pr I & $\begin{array}{l}\text { Tá! Ó! Vamos analisar a fotossíntese. A fotossíntese ela } \\
\text { permite a planta a fazer o quê? }\end{array}$ \\
\hline 342 & Al 3 & $\mathrm{O}$ alimento \\
\hline 343 & Pr I & $\begin{array}{l}\text { Vocês falaram assim fazer seu próprio alimento, } \\
\text { produzir o próprio alimento, o alimento não é a glicose? } \\
\text { (Al s fazem que sim com a cabeça) }\end{array}$ \\
\hline 344 & Pr I & Vocês acham que esse alimento tem energia? \\
\hline 345 & Al 3 & Sim \\
\hline 346 & Pr I & Tem né! Porque que a gente come? \\
\hline
\end{tabular}




\begin{tabular}{|c|c|c|}
\hline 347 & $\mathrm{Al} 6$ & Pra ter energia \\
\hline 348 & Pr I & $\begin{array}{l}\text { Pra ter energia,pra ter nutrientes, principalmente } \\
\text { energia. Então esse aqui sendo o alimento da planta esse } \\
\text { alimento tem energia. Mas de onde vem essa energia? }\end{array}$ \\
\hline 349 & Al 12 & $\begin{array}{l}\text { Professor, mas professor essa folha como ela não está } \\
\text { mais na árvore supõe que ela esteja morta. }\end{array}$ \\
\hline 350 & Pr I & Humm! \\
\hline 351 & Al 12 & Ela não está morta? \\
\hline 352 & $\operatorname{Pr} I$ & $\begin{array}{l}\text { A folha quando a gente arranca da árvore ela ainda tem } \\
\text { capacidade de fazer fotossíntese. }\end{array}$ \\
\hline 353 & Pr II & $\begin{array}{l}\text { Durante um tempo. Depois ela murcha e acaba } \\
\text { morrendo }\end{array}$ \\
\hline 354 & Pr I & $\begin{array}{l}\text { A tendência é ela morrer daqui a pouquinho! Mas pó } \\
\text { enquanto tá tudo funcionando. }\end{array}$ \\
\hline 355 & Al 6 & $\begin{array}{l}\text { Bom! Na minha hipótese é que nessa( aluna aponta para } \\
\text { o tubo de ensaio) como ela recebeu a luz ela fez a } \\
\text { fotossíntese normal e ela não liberou co2 então não fez } \\
\text { a mistura que deu no ácido. Já nessa ( aluna aponta para } \\
\text { o outro tubo de ensaio), ela só respirou porque ela não } \\
\text { tinha luz ela só respirou o que liberou o gás carbônico } \\
\text { que com a junção da água virou ácido. }\end{array}$ \\
\hline 356 & Pr III & $\begin{array}{l}\text { Mas a de cá ( apontando para o tubo de ensaio que } \\
\text { estava sem papel alumínio) você acha que nunca libera } \\
\text { gás carbônico? }\end{array}$ \\
\hline 357 & Al 6 & Essa ... liberou porque ela respirou também. \\
\hline 358 & Pr III & E o que que ela fez com esse gás Carbônico? \\
\hline 359 & Pr III & Pensem! O que que ela fez com esse gás carbônico \\
\hline 360 & Al 6 & A fotossíntese \\
\hline 361 & Pr III & Precisa do gás carbônico pra fazer a fotossíntese? \\
\hline 362 & $\mathrm{Al} 6$ & Sim \\
\hline 363 & Pr II & Você percebeu? \\
\hline 364 & Al 6 & Ah entendi! Ela respirou e também fez a fotossíntese \\
\hline
\end{tabular}




\begin{tabular}{|c|c|c|}
\hline 365 & Pr III & Então explica pro pessoal! \\
\hline 366 & Al 6 & Tá. Nessa aqui ( aponta para os tubos) \\
\hline 367 & Pr II & $\begin{array}{l}\text { Pode levantar (aluna levanta a estante com os tubos de } \\
\text { ensaio) }\end{array}$ \\
\hline 368 & Pr II & Só os tubinhos \\
\hline 369 & $\mathrm{Al} 6$ & $\begin{array}{l}\text { As duas plantas respiram, por isso essa tá mais clara. } \\
\text { Mas essa recebeu luz, então ela teve como fazer a } \\
\text { fotossíntese, ao contrário dessa. }\end{array}$ \\
\hline 370 & Pr III & $\begin{array}{l}\text { E o que acontece na fotossíntese? Alguém mais pode } \\
\text { explica? }\end{array}$ \\
\hline 371 & Al 3 & Ela liberou o oxigênio \\
\hline 372 & Pr II & E usou o que? A luz... \\
\hline 373 & $\mathrm{Al} 3$ & O gás Carbônico \\
\hline 374 & Pr III & $\begin{array}{l}\text { Se ela usou o gás carbônico sobrou gás carbônico pra } \\
\text { fazer o ácido carbônico? }\end{array}$ \\
\hline 375 & Al 3 & $\begin{array}{l}\text { Não!já quando ela respira ela consome o oxigênio e } \\
\text { libera o gás carbônico. }\end{array}$ \\
\hline 376 & $\mathrm{Al} 3$ & $\begin{array}{l}\text { Assim ela tá certa! (aponta para outra aluna) quando ela } \\
\text { faz fotossíntese ela vai usar o gás carbônico e liberar o } \\
\text { oxigênio, já quando ela só respira ela vai usar o } \\
\text { oxigênio e liberar o gás carbônico, aí estando em } \\
\text { contato com a água mudou a cor. }\end{array}$ \\
\hline 377 & Pr III & $\begin{array}{l}\text { Mas porque a diferença na cor? Porque um focou com } \\
\text { cor e outro ficou mais claro. }\end{array}$ \\
\hline 378 & Al 3 & $\begin{array}{l}\text { É porque essa ( pegou os tubos) fez a fotossíntese e } \\
\text { respirou e essa só respirou. }\end{array}$ \\
\hline 379 & Pr III & Se não fez a fotossíntese, não usou o que? \\
\hline 380 & Al 3 & O gás carbônico \\
\hline 381 & Pr III & Entenderam? \\
\hline 382 & Al s & Sim \\
\hline 383 & Pr I & Agora nós vamos escrever o que fizemos no caderno. \\
\hline
\end{tabular}


